\title{
Immobilization of Rocky Flats Graphite Fines Residue
}

by

T. S. Rudisill

RECORDS ADMINISTRATION

Westinghouse Savannah River Company

Savannah River Site

Aiken, South Carolina 29808

DOE Contract No. DE-AC09-96SR18500

This paper was prepared in connection with work done under the above contract number with the U. S. Department of Energy. By acceptance of this paper, the publisher and/or recipient acknowledges the U. S. Government's right to retain a nonexclusive, royalty-free license in and to any copyright covering this paper, along with the right to reproduce and to authorize others to reproduce all or part of the copyrighted paper. 


\section{DISCLAIMER}

This report was prepared as añ account of work sponsored by an agency of the United States Government. Neither the United States Government nor any agency thereof, nor any of their employees, makes any warranty, express or implied, or assumes any legal liability or responsibility for the accuracy, completeness, or usefulness of any information, apparatus, product, or process disclosed, or represents that its use would not infringe privately owned rights. Reference herein to any specific commercial product, process, or service by trade name, trademark, manufacturer, or otherwise does not necessarily constitute or imply its endorsement, recommendation, or favoring by the United States Government or any agency thereof. The views and opinions of authors expressed herein do not necessarily state or reflect those of the United States Government or any agency thereof.

This report has been reproduced directly from the best available copy.

Available to DOE and DOE contractors from the Office of Scientific and Technical Information, P.O. Box 62, Oak Ridge, TN 37831; prices available from (615) 576-8401.

Available to the public from the National Technical Information Service, U.S. Department of Commerce; 5285 Port Royal Road, Springfield, VA 22161. 
WSRC-TR-98-00380

Revision 0

\title{
Immobilization of Rocky Flats Graphite Fines Residue
}

\author{
Tracy S. Rudisill
}

February 1999

Westinghouse Savannah River Company

Building 773-A

Aiken, SC 29808

Prepared for the Los Alamos National Laboratory

94-1 Research and Development Project 
WSRC-TR-98-00380

Revision 0

\title{
Immobilization of Rocky Flats Graphite Fines Residue
}

\author{
By
}

Tracy S. Rudisill

Issued: February 1999

\section{Approvals}

\begin{tabular}{|c|c|}
\hline Tracy 1 Rudisiel & $2 / 10 / 99$ \\
\hline Tracy S. Rfudisill, Author & Date \\
\hline Alare Helleps & $2 / 161$ \\
\hline $\begin{array}{l}\text { Alan G. Phillips, Technital Reviewer } \\
\text { Rocky Flats Environmental Technology Site }\end{array}$ & $2 / 16 / 99$ \\
\hline
\end{tabular}

Los Alamos National Laboratory 


\section{Table of Contents}

Section $\quad$ Page

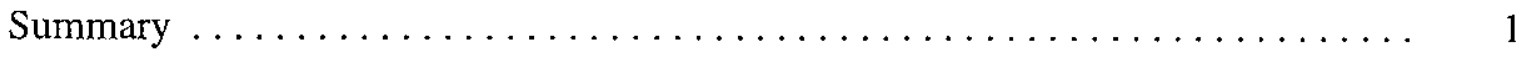

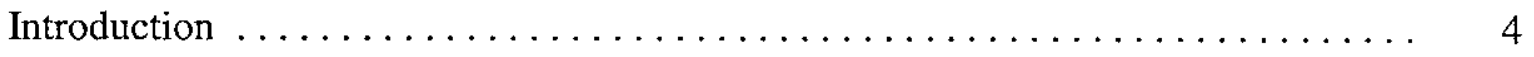

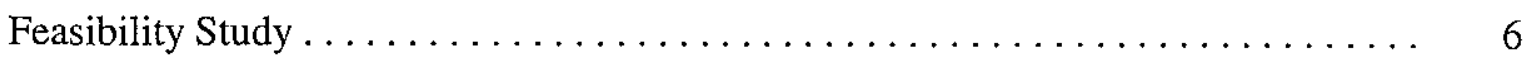

Calcium Fluoride Variability Study $\ldots \ldots \ldots \ldots \ldots \ldots \ldots \ldots \ldots \ldots \ldots \ldots$

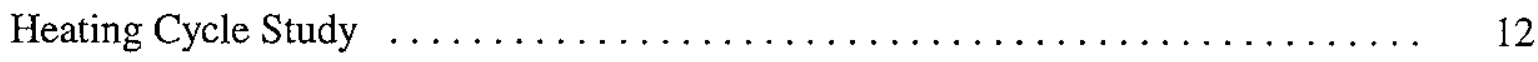

Full-scale Immobilization Experiments $\ldots \ldots \ldots \ldots \ldots \ldots \ldots \ldots \ldots \ldots$

Immobilization of Actual Graphite Fines $\ldots \ldots \ldots \ldots \ldots \ldots \ldots \ldots \ldots$

Furnace Offgas Characterization $\ldots \ldots \ldots \ldots \ldots \ldots \ldots \ldots \ldots \ldots \ldots \ldots \ldots \ldots \ldots \ldots$

Conclusions and Recommendations $\ldots \ldots \ldots \ldots \ldots \ldots \ldots \ldots \ldots \ldots \ldots \ldots \ldots \ldots \ldots \ldots$

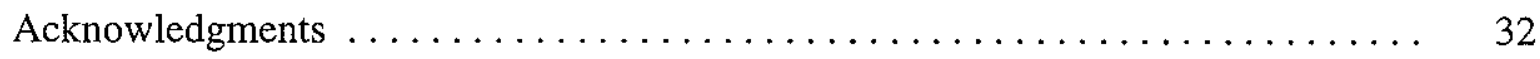

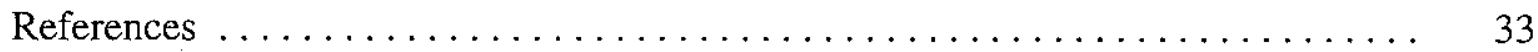

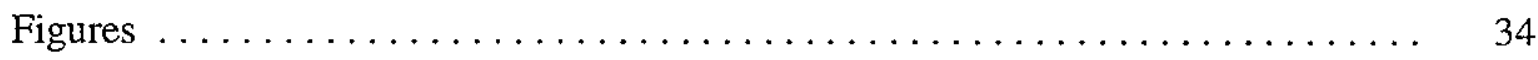

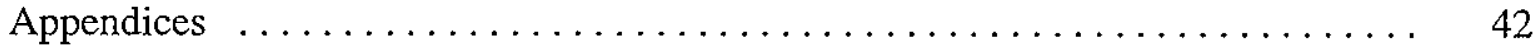




\section{List of Figures}

Page

Figure $1 \quad$ Photomicrograph of Waste Form 10a $\ldots \ldots \ldots \ldots \ldots \ldots \ldots$

Figure $2 \quad$ Cerium Recovery from Graphite Fines Waste Forms $\ldots \ldots \ldots \ldots$

Figure 3 Typical Waste Form Containing $\mathrm{No}^{\mathrm{CaF}_{2}} \ldots \ldots \ldots \ldots$

Figure $4 \quad$ Typical Waste Form with High $\mathrm{CaF}_{2} \ldots \ldots \ldots \ldots \ldots \ldots \ldots \ldots$

Figure $5 \quad$ Cerium Recovery from Graphite Fines Waste Forms . . . . . . . 37

Figure $6 \quad$ Centerline Temperature Profile for Run FS-2 $\ldots \ldots \ldots \ldots \ldots$

Figure $7 \quad$ Full-scale Graphite Fines Waste Form $\ldots \ldots \ldots \ldots \ldots \ldots$

Figure $8 \quad$ Fragments from Waste Form FS-1 $\ldots \ldots \ldots \ldots \ldots \ldots \ldots \ldots$

Figure $9 \quad$ Actual Graphite Fines Waste Form $(\mathrm{RM}-3) \ldots \ldots \ldots \ldots$. . . . 41

Figure $10 \quad$ Fragments from Actual Graphite Fines Waste Form (RM-3) . . . . 41 


\section{List of Tables}

Page

Table $1 \quad$ Composition of Sodium Borosilicate Glass Frit $\ldots \ldots \ldots \ldots$

Table 2 Waste Form Performance during Feasibility Experiments $\ldots \ldots \ldots 8$

Table 3 Waste Form Compositions for $\mathrm{CaF}_{2}$ Variability Study $\ldots \ldots \ldots$

Table 4 Cerium Recoverability - Variation in $\mathrm{CaF}_{2}$ Concentration $\ldots \ldots \ldots 10$

Table 5 Cerium Recoverability - Compaction Prior to Heating $\ldots \ldots \ldots 11$

Table 6 Waste Form Fabrication Temperatures and Heating Times ...... 13

Table $7 \quad$ Cerium Recoverability - Heating Cycle Study $\ldots \ldots \ldots \ldots \ldots$

Table $8 \quad$ Calculation of Cerium Recoveries Using Multiple Analyses $\ldots \ldots \quad 18$

Table 9 Waste Form Fabrication Data for Full-scale Experiments $\ldots \ldots \ldots 20$

Table $10 \quad$ Recoverability Test Results from Full-scale Experiments $\ldots \ldots \ldots 21$

Table $11 \quad$ Fabrication of Actual Graphite Fines Waste Forms $\ldots \ldots \ldots \ldots .24$

Table $12 \quad$ Composition of Graphite Fines Residue $\ldots \ldots \ldots \ldots \ldots \ldots$

Table 13 Recoverability Tests for Actual Graphite Fines Waste Forms . . . $\quad 26$

Table $14 \quad$ Offgas Characterization Experiments $\ldots \ldots \ldots \ldots \ldots \ldots \ldots$ 
WSRC-TR-98-00380

Revision 0

\section{List of Appendices}

Page

Appendix A Plutonium Recoverability Testing $\ldots \ldots \ldots \ldots \ldots \ldots \ldots \ldots \ldots$

Appendix B Waste Form Fabrication Data $\ldots \ldots \ldots \ldots \ldots \ldots \ldots \ldots \ldots$

Appendix C Offgas Analyses for Graphite Fines Immobilization $\ldots \ldots \ldots \ldots$ 
WSRC-TR-98-00380

Revision 0

\title{
Immobilization of Rocky Flats Graphite Fines Residue
}

\author{
Tracy S. Rudisill \\ Westinghouse Savannah River Company \\ Savannah River Site \\ Aiken, SC 29808
}

\section{Summary}

During past operations at the Rocky Flats Environmental Technology Site (Rocky Flats), graphite fines residues were generated from cleaning graphite casting molds. The casting molds were initially coated with calcium fluoride $\left(\mathrm{CaF}_{2}\right)$ to minimized the reaction between molten plutonium metal and the graphite mold. Once the castings were made, the molds were cleaned with a wire brush in preparation for reuse. The residue removed during the cleaning process was calcined at $500^{\circ} \mathrm{C}$ and stored for subsequent plutonium recovery. In 1994, the Defense Nuclear Facility Safety Board's Recommendation 94-1 highlighted the need to stabilize this material and develop a plan for removal from the site. In response to this need, the Savannah River Technology Center was asked to develop an immobilization process as a prerequisite to disposal at the Waste Isolation Pilot Plant.

Due to equipment and processing constraints at Rocky Flats, an immobilization process was developed which microencapsulated the graphite fines by mixing with a glass frit and heating to approximately $700^{\circ} \mathrm{C}$. Since the average plutonium concentration in the graphite fines exceeds $10 \mathrm{wt} \%$, the immobilization process met the intent of safeguards termination criteria by limiting the plutonium recoverability. A recoverability test was based on historical nitric acid/fluoride dissolution methods for recovery of plutonium from Rocky Flats incinerator ash. Waste forms which demonstrated a plutonium release less than $4 \mathrm{~g} / \mathrm{kg}$ of waste form were considered practically irrecoverable by the Rocky Flats product acceptance specification.

The initial development for the graphite fines immobilization process was performed using surrogate materials. Graphite powder and a sodium borosilicate (NBS) glass frit supplied by Rocky Flats were mixed with reagent grade $\mathrm{CaF}_{2}$ and cerium oxide $\left(\mathrm{CeO}_{2}\right)$, the surrogate for plutonium oxide, during fabrication of simulated waste forms. The first experiments demonstrated the feasibility of fabricating $500 \mathrm{~g}$ waste forms using an NBS frit with 9 and $10 \mu \mathrm{m}$ average particle sizes. The waste forms were fabricated at $700^{\circ} \mathrm{C}$ using a $2 \mathrm{hr}$ heating time. As long as the frit to residue ratio was $4: 1$ or greater, the cerium recovery was less than $4 \mathrm{~g} / \mathrm{kg}$, and the waste form met the Rocky Flats product acceptance specification. Following the initial process demonstration, a series of experiments was performed to investigate the impact of varying concentrations of $\mathrm{CaF}_{2}$ on the recovery of cerium from the waste form. Graphite fines containing between 0 and $50 \mathrm{wt} \% \mathrm{CaF}_{2}$ are currently stored at Rocky Flats. Results from these experiments showed no negative impact on the cerium recovery with the recovery actually decreasing at $50 \mathrm{wt} \% \mathrm{CaF}_{2}$ in the simulated graphite fines. 
Smaller scale experiments were performed to define the minimum temperature and time at temperature for a simulated waste forms to pass the recoverability test. The experiments were performed using $125 \mathrm{~g}$ of a 4:1 frit to residue mixture to maintain isothermal conditions within the waste form. The waste forms were fabricated using processing temperatures from 600 to $850^{\circ} \mathrm{C}$ using simulated graphite fines containing the minimum and maximum $\mathrm{CaF}_{2}$ concentrations ( 0 and $50 \mathrm{wt} \%$, respectively). The $\mathrm{CeO}_{2}$ concentration was held constant at $12 \mathrm{wt} \%$. The experiments demonstrated that at least $30 \mathrm{~min}$ at $700^{\circ} \mathrm{C}$ were required for both waste form compositions to pass the recoverability test. Waste forms fabricated with simulated graphite fines containing $50 \mathrm{wt} \% \mathrm{CaF}_{2}$ also passed the recoverability test at 600,650 and $675^{\circ} \mathrm{C}$ using at least a $30 \mathrm{~min}$ heating time; however, waste forms containing no $\mathrm{CaF}_{2}$ failed the test with heating times up to 2.5 hours at these lower temperatures. Surprisingly, waste forms fabricated at 750,800 , and $850^{\circ} \mathrm{C}$ which contained no $\mathrm{CaF}_{2}$ became more resistant to dissolution than waste forms containing $\mathrm{CaF}_{2}$, passing the recoverability test at all heating times greater than $30 \mathrm{~min}$. The increased cerium recovery from the $\mathrm{CaF}_{2}$-containing waste forms was attributed to interaction of the $\mathrm{CaF}_{2}$ with the glass frit as it nears a liquid state.

Five full-scale immobilization experiments (2900 to $3600 \mathrm{~g}$ ) were performed with surrogate materials to demonstrate optimal processing conditions defined with the small-scale studies. In these experiments waste forms were fabricated with a $4: 1$ frit to residue ratio by maintaining the centerline temperature at $700^{\circ} \mathrm{C}$ for 0.5 or $2.0 \mathrm{hr}$. The $\mathrm{CaF}_{2}$ content in the graphite fines simulant was maintained at either 0 or $15 \mathrm{wt} \%$ and the $\mathrm{CeO}_{2}$ concentration held constant at $12 \mathrm{wt} \%$. In general, the recovery of cerium from the full-scale waste forms was higher than for the 125 and $500 \mathrm{~g}$ experiments performed using the same fabrication conditions. Unexpectedly, the addition of $\mathrm{CaF}_{2}$ increased the recovery of cerium from the full-scale waste forms, the opposite effect observed with the small-scale experiments. The decrease in durability was so dramatic that all full-scale waste forms containing $\mathrm{CaF}_{2}$ failed to pass the recoverability test regardless of the fabrication time. The decrease in durability was attributed to interaction of the $\mathrm{CaF}_{2}$ with the glass frit; however, examination of waste form samples by x-ray diffraction showed no alteration phases which could responsible for the decrease in durability.

The final test of the immobilization process was the fabrication of four $500 \mathrm{~g}$ waste forms using actual graphite fines from Los Alamos National Laboratory. In these experiment, nominally $100 \mathrm{~g}$ of graphite fines were mixed with NBS glass frit to achieve a 4:1 frit to residue ratio. The waste forms were heated at $700^{\circ} \mathrm{C}$ using heating times of 0.5 and $2 \mathrm{hr}$. The results from the plutonium recoverability tests were mixed. The waste form fabricated with a $0.5 \mathrm{hr}$ heating time did not consolidate into a disk and failed the test. The three waste forms fabricated with $2 \mathrm{hr}$ heating times either passed or nearly passed the recoverability test. Uncertainties in the plutonium analyses from the recoverability tests would make the plutonium recoveries difficult to distinguish from $4 \mathrm{~g} / \mathrm{kg}$ of waste form at reasonable confidence levels. Therefore, with a slight improvement in the fabrication conditions, such as a small increase in the frit to residue ratio, waste form fabricated at this scale would almost certainly meet Rocky Flats product specification. 
During the immobilization of graphite fines, a small portion of the graphite burns. In an oxidizing atmosphere, the combustion products should be primarily carbon dioxide; however, under slightly reducing conditions carbon monoxide (CO) may form. Carbon monoxide forms explosive mixtures with air from 12.5 to $74.2 \%$ CO. Using Rocky Flats equipment specifications and typical processing conditions, scaled experiments confirmed that $\mathrm{CO}$ concentrations in the explosive range do not form during waste form fabrication. 


\section{Introduction}

During previous nuclear material production activities at the Rocky Flats Environmental Technology Site (Rocky Flats), graphite fines residues were generated from cleaning graphite casting molds. The casting molds were initially coated with calcium fluoride $\left(\mathrm{CaF}_{2}\right)$ to minimize the chemical interaction between molten plutonium metal and the graphite mold. Following the casting operation, the molds were cleaned in preparation for reuse. The cleaning process involved the use of a rotating wire brush to remove residual amounts of plutonium metal, the $\mathrm{CaF}_{2}$ coating, and a small amount of the graphite. The residue was stabilized by heating to $500^{\circ} \mathrm{C}$ in a furnace to oxidize pyrophoric plutonium to plutonium oxide $\left(\mathrm{PuO}_{2}\right)$. This process resulted in the generation of approximately $950 \mathrm{kgs}$ of material which is currently stored at Rocky Flats. The average residue composition is $73 \mathrm{wt} \%$ graphite, $15 \mathrm{wt} \% \mathrm{CaF}_{2}$, and $12 \mathrm{wt} \%$ $\mathrm{PuO}_{2}$.

In 1994, the Defense Nuclear Facility Safety Board's (DNFSB's) Recommendation 94-1 brought to the Department of Energy's (DOE's) attention the potential hazards associated with the continued storage of unstable nuclear materials following the halt in the production of nuclear weapons.[1] Although the graphite fines residues were passivated prior to storage, their longterm stability could not be proven without a detailed characterization. In response the DNFSB's concerns, stabilization and disposition planning at Rocky Flats for plutonium-containing residues and other nuclear materials has included the graphite fines.

The preferred disposition path for graphite fines has evolved since the original plans were formulated by Rocky Flats. Initially, Rocky Flats planned to stabilized the graphite fines by heating in a furnace to nominally $500^{\circ} \mathrm{C}$ to oxidize any residual plutonium metal. The stabilized material would then be transferred to the Waste Isolation Pilot Plant (WIPP) for disposal. This alternative was abandoned when DOE issued safeguards termination limits for special nuclear materials.[2] The guidance provided plutonium concentrations at which safeguards could be terminated or at which Category IV security requirements applied. The plutonium concentrations increased with increasing difficulty of plutonium recovery from the material form. In its present state, plutonium in graphite fines is considered difficult to very difficult to recover which allows termination of physical protection if the plutonium concentration is less than $0.2 \mathrm{wt} \%$ or protection measures equivalent to Category IV requirements if the plutonium concentration is less than $1.0 \mathrm{wt} \%$.

Following the publication of safeguards termination limits, the disposition technology for graphite fines was changed to vitrification; however, it soon became apparent that equipment and processing constraints at Rocky Flats would not allow the fabrication of an amorphous waste form. At that point, the decision was made to develop an immobilization process which microencapsulated the graphite fines by mixing with a glass frit and heating to a temperature less than $800^{\circ} \mathrm{C}$, a furnace offgas processing constraint. The Savannah River Technology Center was asked to develop the immobilization process as part of the 94-1 Research and Development Project at the Los Alamos National Laboratory (LANL). 
Since the $\mathrm{PuO}_{2}$ concentration in the graphite fines residues averages $12 \mathrm{wt} \%$, the immobilization process must meet the intent of the safeguards termination criteria by limiting plutonium recoverability. To provide a quantitative measure of the plutonium recoverability, Rocky Flats developed a standard test procedure for comparing the ease of plutonium recovery from waste forms using a nitric acid flowsheet. The procedure was based on historical methods for recovery of plutonium from Rocky Flats incinerator ash. In the test, the release of plutonium must not exceed $4 \mathrm{~g} / \mathrm{kg}$ of waste form when a 20 gram sample is refluxed for $20-30$ minutes in a $9 \mathrm{M}$ nitric acid $/ 0.25 \mathrm{M} \mathrm{CaF}_{2}$ solution. Waste forms which demonstrate a plutonium release less than $4 \mathrm{~g} / \mathrm{kg}$ of waste form are considered practically irrecoverable by the Rocky Flats product specification and would be sent to the WIPP for disposal. The complete recoverability test procedure is given in Appendix 1.

The development of the immobilization process for graphite fines has proceeded through a series of experimental programs. Initially, a feasibility study was performed to demonstrate that simulated waste forms which pass the pass the recoverability test could be fabricated. In these tests, cerium oxide $\left(\mathrm{CeO}_{2}\right)$ was used as the surrogate for $\mathrm{PuO}_{2}$. Following the feasibility study, a series of experiments was performed in which the concentration of the $\mathrm{CaF}_{2}$ in the simulated graphite fines was varied to measure the impact on $\mathrm{CeO}_{2}$ dissolution during the recoverability test. During these experiments, the impact on the $\mathrm{CeO}_{2}$ dissolution achieved by compressing the simulated residue/glass frit powder prior to heating was also measured. Small-scale isothermal experiments were then performed to define the minimum temperature and time at temperature required for graphite fines waste forms to pass the recoverability test. These experiments were performed to provide data which could be used to minimize the Rocky Flats furnace heating cycle. Full-scale immobilization experiments were conducted following these experiments to demonstrate the optimal processing conditions. The optimal conditions were also demonstrated in a series of experiments using actual graphite fines residues received from the LANL. In an auxiliary task, the equipment specifications and proposed processing conditions for graphite fines immobilization at Rocky Flats were used to design scaled experiments to characterized the furnace offgas. In these experiments, the concentration of carbon monoxide (CO) was measured to understand the potential for generating explosive mixtures of $\mathrm{CO}$ and air during the immobilization process. The experimental procedures and results from each series of experiments are discussed in the following sections of the report. 


\section{Feasibility Study}

\section{Experimental Procedures}

Scouting experiments at the Pacific Northwest National Laboratory (PNNL) demonstrated that the fabrication of a nitric-acid resistant graphite-containing waste form was possible if an extremely fine ( 10 micron or less average particle size) glass frit was used for the immobilization process. In light of this development, SRTC, LANL, and Rocky Flats personnel designed an experimental program to determine if a viable immobilization process could be developed for the graphite fines residues. In this program, immobilization experiments using simulated graphite fines were performed during which the frit particle size and the frit to residue ratio were varied. Recoverability tests were performed on samples of the waste forms to measure the solubility of $\mathrm{CeO}_{2}$ (the surrogate for $\mathrm{PuO}_{2}$ in actual graphite fines) under conditions specified by the plutonium recoverability test (see Appendix A).

In the scouting experiments performed at PNNL, a sodium borosilicate (NBS) glass frit was used for the immobilization process.[3] The composition of the frit is shown in Table 1.

Table 1 Composition of Sodium Borosilicate Glass Frit

\begin{tabular}{lc}
\hline \multicolumn{1}{c}{ Oxide } & $\begin{array}{c}\text { Composition } \\
\text { (wt\%) }\end{array}$ \\
\hline Silicon Oxide $\left(\mathrm{SiO}_{2}\right)$ & 60 \\
Sodium Oxide $\left(\mathrm{Na}_{2} \mathrm{O}\right)$ & 15 \\
Boron Oxide $\left(\mathrm{B}_{2} \mathrm{O}_{3}\right)$ & 10 \\
Aluminum Oxide $\left(\mathrm{Al}_{2} \mathrm{O}_{3}\right)$ & 5 \\
Lithium Oxide $\left(\mathrm{Li}_{2} \mathrm{O}\right)$ & 5 \\
Zirconium Oxide $\left(\mathrm{ZrO}_{2}\right)$ & 5 \\
\hline
\end{tabular}

Since nitric acid-resistant waste forms had already been produced using this frit composition and PNNL was using the frit to develop an immobilization process for Rocky Flats incinerator ash, the frit was also used for the graphite fines feasibility study. The NBS frit used in the study was supplied by Rocky Flats personnel. Two particle size distributions were available. İnitially a frit with a $10 \mu \mathrm{m}$ average particle size was used to demonstrate the immobilization process. Latter a second frit with a $9 \mu \mathrm{m}$ average particle size was produced and used in a series of experiments.

The graphite powder used to formulate the surrogate for these experiments was also supplied by Rocky Flats personnel. The powder was generated in much the same way as the graphite fines residue. A rotating wire brush was used to abrade powder from an actual graphite casting mold. The average particle size of the graphite powder was nominally $25 \mu \mathrm{m}$. The surrogate graphite fines were then formulated by adding reagent grade $\mathrm{CeO}_{2}$ and $\mathrm{CaF}_{2}$. The composition of the surrogate used in these experiments was $73 \%$ graphite, $15 \% \mathrm{CaF}_{2}$, and $12 \% \mathrm{CeO}_{2}$. The masses of the frit and surrogate components were measured using a tared $1 l$ plastic bottle which was sealed and shaken to thoroughly mix the materials. The powder mixture was then poured into a $1200 \mathrm{ml}$ stainless steel beaker. For the feasibility study, nominally $500 \mathrm{~g}$ waste forms were fabricated. 
One of the objectives of the feasibility study was to investigate the impact of the frit to residue ratio on the dissolution of $\mathrm{CeO}_{2}$ during the recoverability test. Frit to residue ratios of $8: 1,6: 1$, 4:1, and $3: 1$ were used to fabricate waste forms using both frit particle sizes. Once the simulated graphite fines and frit mixtures were added to the stainless steel beaker, the waste forms were fabricated by placing the beakers in a Lindberg/Blue M (Model BF51634PBC) muffle furnace for heating. The furnace was programmed to step the temperature to $700^{\circ} \mathrm{C}$ and hold for $2 \mathrm{hr}$. Approximately 10 minutes were required to reach $700^{\circ} \mathrm{C}$. After $2 \mathrm{hr}$ at temperature, the power was discontinued and the furnace and waste forms allowed to cool over night.

When the beakers were removed from the furnace, the mass of the beaker and waste form and the distance to the surface of the waste form from the top of the beaker were measured to allow estimations of the volume and density. Similar measurements were made prior to heating which allowed a comparison of the volume and density data. The waste forms were removed from the stainless steel beaker by tapping the bottom and sides with a hammer. Once removed from the beakers, nominally $20 \mathrm{~g}$ of each waste form were used in a recoverability test. The $+1 / 4$-in to$3 / 8$-in fragments required by the test were generated by placing the waste forms in a plastic bag and crushing with a hammer.

\section{Results and Discussion}

The fabrication and testing data (masses of starting materials, processing conditions, and recoverability test) for each waste form are summarized in Appendix B. The waste forms produced in each experiment were similar in appearance. In each case a compact, circular disk was produced at the bottom of the stainless steel beaker. The waste forms with the higher frit to residue ratios were more difficult to remove from the beaker. Extensive hammering on the bottom and side of the beaker was required to removed the waste forms with frit to residue ratios of 6 and 8 causing the waste forms to fragment upon removal. The waste forms fabricated using frit to residue rations of 3 and 4 were removed without fracturing. The waste forms with the higher frit to residue ratios also appeared more dense especially at the surface where fewer cracks and crevices were seen.

Samples of the waste forms fabricated during these experiments were examined by a scanning electron microscope. A typical photomicrograph showing the microencapsulation of the simulated graphite fines taken from Run Number 10a is shown on Figure 1. The waste form was fabricated using a 6:1 frit to residue ratio with the $10 \mu \mathrm{m}$ (average particle size) frit. Energy dispersive $\mathrm{x}$-ray (EDX) analysis was used to qualitatively identify the chemical compositions of three regions of the sample. The spectrum from spot 1 identified silicon, sodium, aluminum, zirconium, and oxygen, which indicates the presence of glass frit. The spectrum from spot 2 shows the presence of cerium and oxygen and a small amount of silicon, aluminum, and carbon. The spectrum from spot 3 again shows the presence of a small amount of the glass frit components (silicon, aluminum, and oxygen) and large amount of carbon. The spectrum from spot 4 shows the presence of glass frit components, carbon, and calcium.

Recoverability tests were performed using $20 \mathrm{~g}$ samples of each waste form. The tests were completed following the procedure given in Appendix A. Filtrate samples generated during the tests were analyzed for cerium by induction-coupled plasma emission spectroscopy (ICP-ES). 
The results of these tests are summarized in Table 2 as the grams of cerium recovered per kilogram of waste form and plotted on Figure 2 as a function of the frit to residue ratio. The cerium recovery decreases with increasing frit to residue ratio as one would expect. Figure 2 also shows that the decrease in cerium recovery is nearly linear when plotted as a function of the frit to residue ratio. The small difference in average frit particle sizes (10 versus $9 \mu \mathrm{m}$ ) does not have a noticeable impact on the recoverability data. The data in Table 2 demonstrates that waste forms fabricated with frit to residue ratios of 4 or greater pass the recoverability test and are considered practically irrecoverable based on the Rocky Flats product specification.

Table 2 Waste Form Performance during Feasibility Experiments

\begin{tabular}{|c|c|c|c|c|c|}
\hline $\begin{array}{c}\text { Run } \\
\text { Number }\end{array}$ & $\begin{array}{c}\text { Frit } \\
\text { Particle } \\
\text { Size } \\
(\mu \mathrm{m}) \\
\end{array}$ & $\begin{array}{l}\text { Frit to } \\
\text { Residue } \\
\text { Ratio }\end{array}$ & $\begin{array}{c}\text { Cerium } \\
\text { Recoverability } \\
\text { Test } \\
\text { (g Ce/kg Waste Form) }\end{array}$ & $\begin{array}{c}\text { Density of } \\
\text { Waste } \\
\text { Form } \\
\left(\mathrm{g} / \mathrm{cm}^{3}\right) \\
\end{array}$ & $\begin{array}{l}\text { Mass Loss } \\
\text { Upon } \\
\text { Heating } \\
\text { (g) }\end{array}$ \\
\hline 2 & 10 & 8 & 0.41 & 1.70 & 2.35 \\
\hline 3 & 9 & 8 & 0.80 & 1.56 & 2.99 \\
\hline $10 \mathrm{a}$ & 10 & 6 & 1.70 & 1.78 & 3.34 \\
\hline $11 \mathrm{a}$ & 9 & 6 & 1.57 & 1.43 & 4.45 \\
\hline 6 & 10 & 4 & 3.23 & 1.24 & 6.24 \\
\hline 7 & 9 & 4 & 2.72 & 1.13 & 7.03 \\
\hline $10 b$ & 10 & 3 & 4.60 & 1.16 & 7.28 \\
\hline $11 b$ & 9 & 3 & 4.19 & 0.98 & 8.24 \\
\hline
\end{tabular}

Other measures of the waste form performance shown in Table 2 include the final waste form density and the mass loss upon heating. The final densities were estimated using the mass of the waste form and the volume calculated from the distance to the waste form surface from the top of the beaker and the beaker geometry. In general, the density of the waste form increased with increasing frit to residue ratio. This is consistent with the visual observations made during the removal of the waste forms from the stainless steel beakers. The mass loss from the waste form during heating also decreased with increasing frit to residue ratio. Mass losses were attributed to combustion of the graphite powder especially near the surface where the concentration of oxygen remains high during the heating period. A waste form fabricated using a low frit to residue ratio would have a higher concentration of graphite near the surface; therefore, one would expect more of the graphite to be oxidized during heating. 


\section{Calcium Fluoride Variability Study}

\section{Experimental Procedures}

The concentration of $\mathrm{CaF}_{2}$ in the graphite fines residues stored at Rocky Flats ranges between 0 and $50 \mathrm{wt} \%$. Therefore, a series of experiments was conducted to measure the impact of the $\mathrm{CaF}_{2}$ concentration on $\mathrm{CeO}_{2}$ dissolution during the recoverability test. In general, the waste form fabrication process was the same as used in the feasibility studies. The waste forms were formulated using the same graphite powder and NBS glass frit supplied by Rocky Flats. The simulated graphite fines were prepared by adding reagent grade $\mathrm{CaF}_{2}$ and $\mathrm{CeO}_{2}$. The $\mathrm{CaF}_{2}$ concentration was varied between 0 and $50 \mathrm{wt} \%$ in the simulant. The $\mathrm{CeO}_{2}$ concentration was maintained at $12 \mathrm{wt} \%$. The composition of the simulated graphite fines and frit to residue ratios used in the immobilization experiments are summarized in Table 3.

Table 3 Waste Form Compositions for $\mathrm{CaF}_{2}$ Variability Study

\begin{tabular}{ccccccc}
\hline $\begin{array}{c}\text { Run } \\
\text { Number }\end{array}$ & \multicolumn{2}{c}{ Graphite Fines Composition } \\
Graphite & $\begin{array}{c}\mathrm{CaF}_{2} \\
\mathrm{CeO}_{2}\end{array}$ & $\begin{array}{c}\text { Frit to } \\
\text { Residue } \\
\text { Ratio }\end{array}$ & $\begin{array}{c}\text { Frit } \\
\text { Particle } \\
\text { Size } \\
(\mathrm{wt} \%)\end{array}$ & $\begin{array}{c}\text { Compaction } \\
\text { Before } \\
\text { Heating }\end{array}$ \\
\hline $\mathrm{A}$ & 73 & 15 & 12 & 4 & 10 & Yes \\
$\mathrm{B}$ & 88 & 0 & 12 & 4 & 10 & No \\
$\mathrm{C}$ & 63 & 25 & 12 & 4 & 10 & No \\
$\mathrm{D}$ & 38 & 50 & 12 & 4 & 10 & No \\
$\mathrm{E}$ & 38 & 50 & 12 & 4 & 10 & Yes \\
$\mathrm{F}$ & 38 & 50 & 12 & 6 & 10 & Yes \\
$\mathrm{G}$ & 38 & 50 & 12 & 6 & 10 & No \\
$\mathrm{H}$ & 38 & 50 & 12 & 8 & 9 & No \\
\hline
\end{tabular}

The waste forms were fabricated by measuring the desired amount of each component into a tared $1 l$ plastic bottle. The materials were mixed by shaking the bottle and pouring into a 1200 $\mathrm{ml}$ stainless steel beaker. In 3 of the immobilization experiments (A, E, and F) the simulant/frit mixtures were compressed using a Plexiglas ${ }^{\mathrm{TM}}$ plunger prior to heating. The diameter of the plunger was fabricated slightly smaller than the stainless steel beaker allowing the depth of material to be compressed approximately $60 \%$ by applying continuous hand pressure. The objective of these experiments was to measure the impact of increasing the density of the powder (prior to heating) on the cerium recoverability. Each waste form was heated at $700^{\circ} \mathrm{C}$ for 2 hours in the Lindberg/Blue $\mathrm{M}$ muffle furnace. Once the heating period was complete, the furnace was turned off and the waste forms allowed to cool overnight.

Upon removing from the furnace, the waste form/beaker mass and distance from the top of the beaker to the waste form surface were measured to allow calculation of the waste form volume and density. Similar measurements were also made prior to heating. The waste forms were removed from the beakers by tapping the bottom and sides with a hammer and collecting the fragments in a plastic bag. A $20 \mathrm{~g}$ sample of each waste form was crushed to the required size $(+1 / 4$-in to-3/8-in fragments) and used in a cerium recoverability test. 
Results and Discussion

The fabrication and testing data (masses of starting materials, processing conditions, and recoverability test) for each waste form are summarized in Appendix B. The appearance of the waste forms fabricated during this series of experiments was similar to the waste forms produced during the feasibility experiments except for those containing $50 \mathrm{wt} \% \mathrm{CaF}_{2}$ in the simulated graphite fines. These waste forms tended to consolidate into a thinner disk and shrank away from the beaker wall during heating. The high $\mathrm{CaF}_{2}$-containing waste forms were also more difficult to remove from the stainless steel beaker, sometimes requiring deformation of the beaker due to intense hammering. The excessive force required to dislodge the waste forms from the beakers caused fragmentation during the removal process.

Cerium recoverability test were performed using $20 \mathrm{~g}$ samples from each waste form. The tests were completed following the procedure given in Appendix A. A sample of the filtrate from each recoverability test was analyzed for cerium by ICP-ES. The results of these tests are summarized and compared with selected data from the feasibility experiments in Tables 4 and 5. Table 4 provides a comparison of the cerium recoverability from waste forms fabricated with varying concentrations of $\mathrm{CaF}_{2}$.

Table 4 Cerium Recoverability - Variation in $\mathrm{CaF}_{2}$ Concentration

\begin{tabular}{ccccc}
\hline \hline $\begin{array}{c}\text { Run } \\
\text { Number }\end{array}$ & $\begin{array}{c}\text { Frit to } \\
\text { Residue Ratio }\end{array}$ & $\begin{array}{c}\text { Frit Particle } \\
\text { Size } \\
(\mu \mathrm{m})\end{array}$ & $\begin{array}{c}\mathrm{CaF}_{2} \\
\text { Content } \\
(\mathrm{w} \text { t\%) }\end{array}$ & $\begin{array}{c}\text { Cerium } \\
\text { Recoverability Test } \\
(\mathrm{g} \text { Ce/kg Waste Form) }\end{array}$ \\
\hline $\mathrm{B}$ & 4 & 10 & 0 & 3.21 \\
6 & 4 & 10 & 15 & 3.23 \\
7 & 4 & 9 & 15 & 2.72 \\
$\mathrm{C}$ & 4 & 10 & 25 & 3.22 \\
$\mathrm{D}$ & 4 & 10 & 50 & $1.74^{(1)}$ \\
\hline $10 \mathrm{a}$ & 6 & 10 & 15 & 1.70 \\
$11 \mathrm{a}$ & 6 & 9 & 15 & 1.57 \\
$\mathrm{G}$ & 6 & 10 & 50 & 0.56 \\
\hline 1 & 8 & 10 & 15 & 0.41 \\
2 & 8 & 9 & 15 & 0.80 \\
$\mathrm{H}$ & 8 & 9 & 50 & 0.33 \\
\hline
\end{tabular}

(1) Recoverability Test was mistakenly terminated after only $15 \mathrm{~min}$.

Table 5 compares the cerium recoverability from waste forms which were fabricated with and without compaction of the powder prior to heating. 
WSRC-TR-98-00380

Revision 0

Table 5 Cerium Recoverability - Compaction Prior to Heating

\begin{tabular}{cccccc}
\hline \hline $\begin{array}{c}\text { Run } \\
\text { Number }\end{array}$ & $\begin{array}{c}\text { Frit to } \\
\text { Residue } \\
\text { Ratio }\end{array}$ & $\begin{array}{c}\text { Frit Particle } \\
\text { Size }\end{array}$ & $\begin{array}{c}\mathrm{CaF}_{2} \\
\text { Content }\end{array}$ & $\begin{array}{c}\text { Compaction } \\
\text { Before } \\
\text { Heating }\end{array}$ & $\begin{array}{c}\text { Cerium } \\
\text { Recoverability } \\
\text { Test }\end{array}$ \\
\hline A & 4 & 10 & 15 & Yes & 3.54 \\
6 & 4 & 10 & 15 & No & 3.23 \\
7 & 4 & 9 & 15 & No & 2.72 \\
\hline E & 4 & 10 & 50 & Yes & 1.65 \\
$D$ & 4 & 10 & 50 & No & $1.74^{(1)}$ \\
\hline F & 6 & 10 & 50 & Yes & 0.63 \\
G & 6 & 10 & 50 & No & 0.56 \\
\hline
\end{tabular}

(1) Recoverability Test was mistakenly terminated after only $15 \mathrm{~min}$.

The recovery of cerium from the waste forms fabricated during this series of experiments (Runs A through $\mathrm{H}$ ) was always less than $4 \mathrm{~g} / \mathrm{kg}$ of waste form. The data presented in Table 4 shows that increasing concentrations of $\mathrm{CaF}_{2}$ do not have a detrimental effect on the cerium recovery. In fact, the recovery of cerium from waste forms containing $50 \mathrm{wt} \% \mathrm{CaF}_{2}$ in the simulated graphite fines actually decreased. The decrease was attributed to the fluxing ability of $\mathrm{CaF}_{2}$ which produced a denser waste form. An increase in the waste form density was generally observed following fabrication with high levels of $\mathrm{CaF}_{2}$. A higher density implies the waste form is less porous which reduces the available surface area during the dissolution step in the recoverability test; therefore, less cerium dissolves.

Compaction of the simulated residue/glass frit powder prior to heating did not have an effect on the $\mathrm{CeO}_{2}$ dissolution during the recoverability test. The waste forms fabricated in this manner appeared more homogeneous; however, the cerium recovery was not significantly different than from uncompacted waste forms (see Table 5). 


\section{Heating Cycle Study}

\section{Experimental Procedures}

The immobilization of the graphite fines residue at Rocky Flats will utilize a large muffle furnace with an approximate $0.03 \mathrm{~m}^{3}$ cavity. A stainless steel can which has an approximate $18-\mathrm{cm}$ diameter and is $21-\mathrm{cm}$ tall will be used to contain the graphite fines/frit mixtures during the immobilization process. Heating the furnace, container, and waste form to the desired temperature and cooling to point where the waste form can be removed from the furnace will require a substantial amount of time. In order to minimize the furnace heating and cooling cycle, the immobilization process should be performed using the minimum temperature and time required for the waste form to pass the recoverability test.

To define the minimum temperature and time required to produce a waste form which meets the Rocky Flats product specification, a series of experiments was performed in which waste forms were fabricated using varying immobilization temperatures and times. The waste form size was limited to $125 \mathrm{~g}$ in order to minimize the temperature gradients within the waste form. The frit to residue ratio was set at 4:1 for all experiments. Two compositions of simulated graphite fines were used to fabricate waste forms at each temperature/time combination. The compositions, 88 wt $\%$ graphite $/ 12$ wt $\% \mathrm{CeO}_{2}$ and 38 wt\% graphite $/ 15 \mathrm{wt} \% \mathrm{CaF}_{2} / 12 \mathrm{wt} \% \mathrm{CeO}_{2}$ represented the extremes of the $\mathrm{CaF}_{2}$ concentration in the actual graphite fines.

The waste forms were fabricated using the same techniques as described for the feasibility and variability studies. The desired amount of each component was measured into a $1 l$ plastic bottle, mixed, and transferred to a $10.4-\mathrm{cm}$ diameter by $13.1-\mathrm{cm}$ tall stainless steel beaker. The graphite powder and NBS glass frit used in the experiments were supplied by Rocky Flats. Four waste forms were fabricated at the same time using the Lindberg/Blue $\mathrm{M}$ muffle furnace. The furnace temperature controller was programmed to step the temperature to the fabrication temperature. The ramp time was typically 10 to 15 minutes, depending upon the desired final temperature. Once the furnace reached temperature, the heating cycle timing began. The first set of waste forms containing the two graphite fines formulations was then removed from the furnace (at temperature) at the desired time. The second set of waste forms was removed 30 minutes later. The fabrication temperatures and heating times used to fabricate the waste forms are summarized in Table 6.

Once the waste forms had cooled, the waste form/beaker mass and distance from the top of the beaker to the waste form surface were recorded to allow calculation of the waste form volume and density. Similar measurements were also made prior to heating. The waste forms were removed from the cans by tapping the bottom and sides with a hammer and collecting the waste form or waste form fragments in a plastic bag. A $20 \mathrm{~g}$ sample of each waste form was prepared for the recoverability test by crushing the fragments to the required size $(+1 / 4$-in to $-3 / 8$-in) with a hammer. 
Table 6 Waste Form Fabrication Temperatures and Heating Times

\begin{tabular}{|c|c|c|}
\hline Run Number & $\begin{array}{c}\text { Fabrication Temperature } \\
\left({ }^{\circ} \mathrm{C}\right)\end{array}$ & $\begin{array}{l}\text { Heating Time } \\
\text { (hr) }\end{array}$ \\
\hline 1a & 600 & 0.0 \\
\hline $1 \mathrm{~b}$ & 600 & 0.0 \\
\hline $2 \mathrm{a}$ & 600 & 0.5 \\
\hline $2 b$ & 600 & 0.5 \\
\hline $3 a$ & 850 & 0.0 \\
\hline $3 b$ & 850 & 0.0 \\
\hline $4 \mathrm{a}$ & 850 & 0.5 \\
\hline $4 b$ & 850 & 0.5 \\
\hline $5 a$ & 600 & 1.0 \\
\hline $5 b$ & 600 & 1.0 \\
\hline $6 \mathrm{a}$ & 600 & 1.5 \\
\hline $6 b$ & 600 & 1.5 \\
\hline $7 \mathrm{a}$ & 700 & 0.5 \\
\hline $7 b$ & 700 & 0.5 \\
\hline $8 \mathrm{a}$ & 700 & 1.0 \\
\hline $8 b$ & 700 & 1.0 \\
\hline $9 \mathrm{a}$ & 650 & 0.5 \\
\hline $9 b$ & 650 & 0.5 \\
\hline $10 \mathrm{a}$ & 650 & 1.0 \\
\hline $10 \mathrm{~b}$ & 650 & 1.0 \\
\hline $11 \mathrm{a}$ & 600 & 2.0 \\
\hline $11 \mathrm{~b}$ & 600 & 2.0 \\
\hline $12 \mathrm{a}$ & 600 & 2.5 \\
\hline $12 b$ & 600 & 2.5 \\
\hline $13 a$ & 850 & 1.0 \\
\hline $13 b$ & 850 & 1.0 \\
\hline $14 \mathrm{a}$ & 850 & 1.5 \\
\hline $14 b$ & 850 & 1.5 \\
\hline $15 \mathrm{a}$ & 650 & 1.5 \\
\hline $15 b$ & 650 & 1.5 \\
\hline $16 \mathrm{a}$ & 650 & 2.0 \\
\hline $16 \mathrm{~b}$ & 650 & 2.0 \\
\hline $17 \mathrm{a}$ & 675 & 0.5 \\
\hline $17 b$ & 675 & 0.5 \\
\hline $18 \mathrm{a}$ & 675 & 1.0 \\
\hline $18 b$ & 675 & 1.0 \\
\hline
\end{tabular}


WSRC-TR-98-00380

Revision 0

Table 6 Continued

\begin{tabular}{ccc}
\hline \hline Run Number & $\begin{array}{c}\text { Fabrication Temperature } \\
\left({ }^{\circ} \mathrm{C}\right)\end{array}$ & $\begin{array}{c}\text { Heating Time } \\
(\mathrm{hr})\end{array}$ \\
\hline $19 \mathrm{a}$ & 850 & 1.0 \\
$19 \mathrm{~b}$ & 850 & 1.0 \\
$20 \mathrm{a}$ & 850 & 1.5 \\
$20 \mathrm{~b}$ & 850 & 1.5 \\
$21 \mathrm{a}$ & 800 & 0.5 \\
$21 \mathrm{~b}$ & 800 & 0.5 \\
$22 \mathrm{a}$ & 800 & 1.0 \\
$22 \mathrm{~b}$ & 800 & 1.0 \\
$23 \mathrm{a}$ & 750 & 0.5 \\
$23 \mathrm{~b}$ & 750 & 0.5 \\
$24 \mathrm{a}$ & 750 & 1.0 \\
$24 \mathrm{~b}$ & 750 & 1.0 \\
$25 \mathrm{a}$ & 750 & 1.5 \\
$25 \mathrm{~b}$ & 750 & 1.5 \\
$26 \mathrm{a}$ & 750 & 2.0 \\
$26 \mathrm{~b}$ & 750 & 2.0 \\
$27 \mathrm{a}$ & 800 & 1.5 \\
$27 \mathrm{~b}$ & 800 & 1.5 \\
$28 \mathrm{a}$ & 800 & 2.0 \\
$28 \mathrm{~b}$ & 800 & 2.0 \\
\hline
\end{tabular}

$\mathrm{a} \equiv 88 \mathrm{wt} \%$ graphite $/ 12 \mathrm{wt} \% \mathrm{CeO}_{2}$ simulant composition

$\mathrm{b} \equiv 38 \mathrm{wt} \%$ graphite / $15 \mathrm{wt} \% \mathrm{CaF}_{2} / 12 \mathrm{wt} \% \mathrm{CeO}_{2}$ simulant composition

\section{Results and Discussion}

The fabrication and testing data (masses of starting materials, processing conditions, and recoverability test) for each waste form are summarized in Appendix B. The products from this series of experiments were hard, compact waste forms with the exception of the waste forms fabricated at $600^{\circ} \mathrm{C}$ which were removed from the furnace when the temperature was reached. Under these conditions, the waste forms did not consolidate. The waste forms fabricated with 0 ("a" runs) and $50 \mathrm{wt} \%$ ("b" runs) $\mathrm{CaF}_{2}$ in the simulated graphite fines were easily distinguished. The waste forms with no $\mathrm{CaF}_{2}$ typically receded from the wall of the can leaving a $3-5 \mathrm{~mm}$ void. Usually, the waste form could be removed from the can as an intact disk. The surface of waste forms with no $\mathrm{CaF}_{2}$ were rough and often cracked. Small beads of consolidated glass were usually present on the surface $A$ photograph of a typical waste form containing no $\mathrm{CaF}_{2}$ is shown on Figure 3. In contrast, waste forms containing high levels of $\mathrm{CaF}_{2}$ were not cracked and typically exhibited a smooth surface (see Figure 4). If a void space was present at the wall of the can it was partially filled with material. The presence of high levels of $\mathrm{CaF}_{2}$ appeared to generate a more fluid waste form at temperature. This is likely attributed to the fluxing ability of $\mathrm{CaF}_{2}$. 
The waste forms with high levels of $\mathrm{CaF}_{2}$ were more difficult to remove from the can. Extensive hammering on the bottom and side of the can was required to remove these waste forms. The hammer blows tended to shatter the waste form generating fragments and powdered material.

Recoverability tests (see Appendix A) performed for each waste form are summarized in Table 7. The filtrate samples generated during the tests were analyzed for cerium by ICP-ES.

Table 7 Cerium Recoverability - Heating Cycle Study

\begin{tabular}{|c|c|c|c|}
\hline $\begin{array}{c}\text { Run } \\
\text { Number }\end{array}$ & $\begin{array}{c}\text { Fabrication } \\
\text { Temperature } \\
\left({ }^{\circ} \mathrm{C}\right) \\
\end{array}$ & $\begin{array}{l}\text { Heating } \\
\text { Time } \\
\text { (hr) } \\
\end{array}$ & $\begin{array}{c}\text { Cerium } \\
\text { Recoverability } \\
\text { Test } \\
\text { (g Ce/kg Waste Form) }\end{array}$ \\
\hline la & 600 & 0.0 & $(1)$ \\
\hline $1 b$ & 600 & 0.0 & $(1)$ \\
\hline $2 a$ & 600 & 0.5 & 7.33 \\
\hline $2 b$ & 600 & 0.5 & 1.67 \\
\hline $3 a$ & 850 & 0.0 & 4.41 \\
\hline $3 b$ & 850 & 0.0 & 2.22 \\
\hline $4 a$ & 850 & 0.5 & 1.23 \\
\hline $4 b$ & 850 & 0.5 & 3.65 \\
\hline $5 a$ & 600 & 1.0 & 6.66 \\
\hline $5 b$ & 600 & 1.0 & 1.34 \\
\hline $6 a$ & 600 & 1.5 & 6.44 \\
\hline $6 b$ & 600 & 1.5 & 1.52 \\
\hline $7 \mathrm{a}$ & 700 & 0.5 & 2.94 \\
\hline $7 b$ & 700 & 0.5 & 1.75 \\
\hline $8 \mathrm{a}$ & 700 & 1.0 & 3.24 \\
\hline $8 b$ & 700 & 1.0 & 1.64 \\
\hline $9 a$ & 650 & 0.5 & 8.50 \\
\hline $9 b$ & 650 & 0.5 & 2.09 \\
\hline $10 \mathrm{a}$ & 650 & 1.0 & 5.41 \\
\hline $10 \mathrm{~b}$ & 650 & 1.0 & 1.19 \\
\hline $11 \mathrm{a}$ & 600 & 2.0 & 8.21 \\
\hline $11 b$ & 600 & 2.0 & 1.91 \\
\hline $12 \mathrm{a}$ & 600 & 2.5 & 11.92 \\
\hline $12 b$ & 600 & 2.5 & 1.43 \\
\hline
\end{tabular}

(1) Recoverability Test was not performed 
Table 7 Continued

\begin{tabular}{|c|c|c|c|}
\hline $\begin{array}{c}\text { Run } \\
\text { Number }\end{array}$ & $\begin{array}{c}\text { Fabrication } \\
\text { Temperature } \\
\left({ }^{\circ} \mathrm{C}\right) \\
\end{array}$ & $\begin{array}{l}\text { Heating } \\
\text { Time } \\
(\mathrm{hr}) \\
\end{array}$ & $\begin{array}{c}\text { Cerium } \\
\text { Recoverability } \\
\text { Test } \\
\text { (g Ce/kg Waste Form) }\end{array}$ \\
\hline $13 a-1$ & 850 & 1.0 & $1.68^{(2)}$ \\
\hline $13 a-2$ & 850 & 1.0 & 1.79 \\
\hline $13 b-1$ & 850 & 1.0 & $4.81^{(2)}$ \\
\hline $13 b-2$ & 850 & 1.0 & 4.39 \\
\hline $14 a-1$ & 850 & 1.5 & $1.35^{(2)}$ \\
\hline $14 a-2$ & 850 & 1.5 & 1.50 \\
\hline $14 b-1$ & 850 & 1.5 & $3.55^{(2)}$ \\
\hline $14 b-2$ & 850 & 1.5 & 3.99 \\
\hline $15 \mathrm{a}$ & 650 & 1.5 & $5.25^{(2)}$ \\
\hline $15 b$ & 650 & 1.5 & $1.44^{(2)}$ \\
\hline $16 \mathrm{a}$ & 650 & 2.0 & $5.75^{(2)}$ \\
\hline $16 \mathrm{~b}$ & 650 & 2.0 & $1.48^{(2)}$ \\
\hline $17 \mathrm{a}$ & 675 & 0.5 & $4.74^{(2)}$ \\
\hline $17 \mathrm{~b}$ & 675 & 0.5 & $1.45^{(2)}$ \\
\hline $18 \mathrm{a}$ & 675 & 1.0 & $4.96^{(2)}$ \\
\hline $18 \mathrm{~b}$ & 675 & 1.0 & $1.66^{(2)}$ \\
\hline $19 a$ & 850 & 1.0 & 2.09 \\
\hline $19 b$ & 850 & 1.0 & 4.74 \\
\hline $20 a$ & 850 & 1.5 & 1.70 \\
\hline $20 \mathrm{~b}$ & 850 & 1.5 & 3.93 \\
\hline $21 a$ & 800 & 0.5 & 2.82 \\
\hline $21 b$ & 800 & 0.5 & 3.32 \\
\hline $22 a$ & 800 & 1.0 & 2.80 \\
\hline $22 b$ & 800 & 1.0 & 4.08 \\
\hline $23 a$ & 750 & 0.5 & 3.53 \\
\hline $23 b$ & 750 & 0.5 & 3.90 \\
\hline $24 a$ & 750 & 1.0 & 3.14 \\
\hline $24 b$ & 750 & 1.0 & 4.35 \\
\hline $25 a$ & 750 & 1.5 & 3.92 \\
\hline $25 b$ & 750 & 1.5 & 2.82 \\
\hline $26 a$ & 750 & 2.0 & 2.79 \\
\hline $26 \mathrm{~b}$ & 750 & 2.0 & 3.49 \\
\hline $27 \mathrm{a}$ & 800 & 1.5 & 3.46 \\
\hline $27 \mathrm{~b}$ & 800 & 1.5 & 6.23 \\
\hline $28 \mathrm{a}$ & 800 & 2.0 & 2.59 \\
\hline $28 b$ & 800 & 2.0 & 3.25 \\
\hline
\end{tabular}

(2) Average value from 3 cerium analyses 
To illustrate the relationship between the waste form fabrication temperature/heating time, the two graphite fines compositions, and the cerium recoverability, the data from Table 7 were plotted on Figure 5. If the waste forms fabricated from both graphite fines compositions passed the recoverability test (i.e. cerium recovery was less than $4 \mathrm{~g} / \mathrm{kg}$ of waste form) the data points are shown as open circles. The data points represented by open squares denote fabrication conditions where waste forms containing no $\mathrm{CaF}_{2}$ passed the recoverability test. Open triangles represent fabrication conditions where waste forms containing $50 \mathrm{wt} \% \mathrm{CaF}_{2}$ in the simulated graphite fines passed the recoverability test. The closed circle represents the waste forms fabricated at $600^{\circ} \mathrm{C}$ and removed from the furnace as soon as the setpoint was reached which failed the recoverability test. Figure 5 shows that $700^{\circ} \mathrm{C}$ is the only fabrication temperature which produced satisfactory waste forms from both graphite fines compositions for all heating times. At temperatures below $700^{\circ} \mathrm{C}$ the consolidated waste forms containing $\mathrm{CaF}_{2}$ ("b" runs) passed the recoverability test while those waste forms containing no $\mathrm{CaF}_{2}$ failed the test. These results were attributed to the fluxing ability of $\mathrm{CaF}_{2}$ which produced a denser waste form with less surface area and more resistance to dissolution. Generally the measured density of the waste form after heating was greater for the waste forms containing $\mathrm{CaF}_{2}$ (see Appendix B, Table B.9).

In contrast to waste forms fabricated at or below $700^{\circ} \mathrm{C}$, waste forms fabricated at higher temperatures showed an opposite trend when the simulated graphite fines contained $50 \mathrm{wt} \%$ $\mathrm{CaF}_{2}$. The recovery of cerium was generally greater from these waste forms than the waste forms fabricated without $\mathrm{CaF}_{2}$. The heating time also appears to have an effect on the recovery of cerium from waste forms containing the $\mathrm{CaF}_{2}$ at temperatures greater than $700^{\circ} \mathrm{C}$. Both waste form compositions fabricated at 750,800 , and $850^{\circ} \mathrm{C}$ passed the recoverability test with a $0.5 \mathrm{hr}$ heating time, but failed at one or more heating times longer than $0.5 \mathrm{hr}$. The increase in cerium recovery from the $\mathrm{CaF}_{2}$-containing waste forms is likely attributed to interaction of the $\mathrm{CaF}_{2}$ with the glass frit as the glass nears a molten state.

The reproducibility of the results from the recoverability tests was accessed by performing a second test on the waste forms fabricated during Runs $13 \mathrm{a} / \mathrm{b}$ and $14 \mathrm{a} / \mathrm{b}$. From Table 7 , one can see there is good agreement between the cerium recoveries obtained from different samples of the same waste form. The temperature and heating time used to fabricate these waste forms were also reproduced during the fabrication of waste forms $19 \mathrm{a} / \mathrm{b}$ and $20 \mathrm{a} / \mathrm{b}$. The cerium recoveries for these runs are also in good agreement with the results obtained for Runs $13 \mathrm{a} / \mathrm{b}$ and $14 \mathrm{a} / \mathrm{b}$. The reproducibility of the cerium analyses obtained by ICP-ES was checked by analyzing the same filtrate samples from several recoverability tests by induction-coupled plasma mass spectroscopy (ICP-MS). A second sample was also removed from the stored filtrates using the same sampling procedure and analyzed by ICP-MS. The results from this comparison are presented in Table 8.

The multiple cerium analyses in Table 8 were used to calculate the standard deviation in the average cerium recoverability. The relative standard deviation for the waste form recoverabilities ranges between 0 and $30 \%$; however, the values average $11 \%$ which is a reasonable expectation for the precision of multiple elemental analyses. 
WSRC-TR-98-00380

Revision 0

Table 8 Calculation of Cerium Recoveries Using Multiple Analyses

\begin{tabular}{|c|c|c|c|c|c|c|}
\hline $\begin{array}{l}\text { Run } \\
\text { No. }\end{array}$ & $\begin{array}{c}\text { Cerium }^{(1)} \\
\text { Analysis } \\
\text { No. } 1 \\
(\mathrm{mg} / \mathrm{l}) \\
\end{array}$ & $\begin{array}{c}\text { Cerium }^{(2)} \\
\text { Analysis } \\
\text { No. } 2 \\
(\mathrm{mg} / l)\end{array}$ & $\begin{array}{c}\text { Cerium }^{(3)} \\
\text { Analysis } \\
\text { No.3 } \\
(\mathrm{mg} / l) \\
\end{array}$ & $\begin{array}{c}\text { Average } \\
\text { Cerium } \\
\text { Recovery } \\
\text { (g/kg waste form) }\end{array}$ & $\begin{array}{c}\text { Standard } \\
\text { Deviation } \\
\text { (g/kg waste form) }\end{array}$ & $\begin{array}{c}\text { Relative } \\
\text { Standard } \\
\text { Deviation } \\
(\%) \\
\end{array}$ \\
\hline $13 a-1$ & 364 & 400 & 400 & 1.68 & 0.09 & 5 \\
\hline $13 b-1$ & 994 & 987 & 987 & 4.81 & 0.02 & 0 \\
\hline $14 a-1$ & 256 & 315 & 315 & 1.35 & 0.15 & 11 \\
\hline $14 b-1$ & 912 & 649 & 649 & 3.55 & 0.73 & 21 \\
\hline $15 \mathrm{a}$ & 1143 & 1251 & 1159 & 5.25 & 0.26 & 5 \\
\hline $15 b$ & 256 & 286 & 357 & 1.44 & 0.25 & 17 \\
\hline $16 a$ & 1289 & 1261 & 1245 & 5.75 & 0.10 & 2 \\
\hline $16 b$ & 303 & 333 & 305 & 1.48 & 0.08 & 5 \\
\hline $17 \mathrm{a}$ & 945 & 1041 & 1214 & 4.74 & 0.61 & 13 \\
\hline $17 \mathrm{~b}$ & 304 & 312 & 383 & 1.45 & 0.19 & 13 \\
\hline $18 \mathrm{a}$ & 1026 & 1075 & 1146 & 4.96 & 0.28 & 6 \\
\hline $18 \mathrm{~b}$ & 409 & 431 & 237 & 1.66 & 0.49 & 30 \\
\hline
\end{tabular}

(1) Analysis performed by ICP-ES

(2) Analysis performed by ICP-MS using No. 1 sample.

(3) Analysis performed by ICP-MS using a second sample 


\section{Full-scale Immobilization Experiments}

\section{Experimental Procedures}

The use of a stainless steel can which has an approximate $18-\mathrm{cm}$ diameter and is 23-cm tall has been proposed for the immobilization of the graphite fines residues at Rocky Flats. The volume of the can is sufficient to hold in excess of $3 \mathrm{~kg}$ of graphite fines and glass frit. In order to identify any issues associated with the scale-up of the immobilization process from the $125-500 \mathrm{~g}$ scale to full-scale, a series of experiments was performed in which full-scale waste forms were produced. Optimal conditions identified during the heating cycle studies were used for the waste form fabrications.

In the first two experiments, waste forms were fabricated using simulated graphite fines containing no $\mathrm{CaF}_{2}$. In the last three experiments, the average Rocky Flats graphite fines composition was used ( $73 \mathrm{wt} \%$ graphite, $15 \mathrm{wt} \% \mathrm{CaF}_{2}$, and $12 \mathrm{wt} \% \mathrm{CeO}_{2}$, the surrogate for $\mathrm{PuO}_{2}$ ). A 4:1 frit to residue ratio was used in all experiments. The waste forms were fabricated using the same techniques as described for the previous studies. The graphite powder and NBS glass frit used in the experiments were supplied by Rocky Flats. The desired amount of each waste form component was measured into a $4 l$ plastic bottle, mixed by shaking the bottle, and transferred to the stainless steel can.

The heating time for waste form fabrication was initially based on the $0.5 \mathrm{hr}$ requirement identified during the heating cycle studies. The final waste form was fabricated using a $2 \mathrm{hr}$ heating time. The heating time was based on the centerline temperature of the waste form due to the size and resulting lag in the temperature response in the interior of the waste form. The centerline temperature was measured by drilling a small hole through the wall of the stainless steel can 2 -in from the bottom and inserting a OMEGA ${ }^{\circledR}$ Nextel Ceramic Type $\mathrm{K}$ thermocouple through the hole when the simulated residue/frit mixture was added to the can. The thermocouple leads were fed through a gas entry port out the back of the Lindberg/Blue M muffle furnace and connected to an OMEGA ${ }^{\circledR}$ benchtop temperature monitor (Model MDSSD465-KC).

During the initial experiment, a furnace setpoint of $700^{\circ} \mathrm{C}$ was used to fabricate the waste form. Due to the size of the waste form and the resulting temperature lag at the centerline; the total heating time was approximately 6 hours. The $0.5 \mathrm{hr}$ heating time was actually started at $685^{\circ} \mathrm{C}$, $5.5 \mathrm{hr}$ after the furnace was started. The final temperature achieved during the fabrication was only $687^{\circ} \mathrm{C}$. In order to decrease the heatup time, the remaining waste forms were fabricated by initially using a furnace setpoint of $750^{\circ} \mathrm{C}$ until the centerline temperature reached $700^{\circ} \mathrm{C}$. At that point in the heating cycle, the furnace setpoint was adjusted downward to $700^{\circ} \mathrm{C}$. With this strategy the centerline temperature typically overshot $12-15^{\circ} \mathrm{C}$. A centerline temperature profile typical of this heating strategy is shown on Figure 6 . At the conclusion of the timed heating period, power to the furnace was switched off and the waste form allowed to cool. The furnace door was opened to speedup the cooling process and allow handling of the waste form the following day. The composition of the simulated graphite fines used in the experiments and the fabrication conditions for the waste forms are summarized in Table 9. 
Table 9 Waste Form Fabrication Data for Full-scale Experiments

\begin{tabular}{cccccc}
\hline \hline $\begin{array}{c}\text { Run } \\
\text { Number }\end{array}$ & \multicolumn{2}{c}{$\begin{array}{c}\text { Graphite Fines Composition } \\
\text { Graphite }\end{array}$} & $\begin{array}{c}\mathrm{CaF}_{2} \\
\mathrm{CeO}_{2}\end{array}$ & $\begin{array}{c}\text { Centerline } \\
\text { Fabrication } \\
\text { Temperature } \\
(\text { wt } \%)\end{array}$ & $\begin{array}{c}\text { Centerline } \\
\text { Heating } \\
\text { Time } \\
(\mathrm{wt} \%)\end{array}$ \\
\hline FS-1 & 88 & 0 & 12 & 700 & 0.5 \\
FS-2 & 88 & 0 & 12 & 700 & 0.5 \\
FS-3 & 73 & 15 & 12 & 700 & 0.5 \\
FS-4 & 73 & 15 & 12 & 700 & 0.5 \\
FS-5 & 73 & 15 & 12 & 700 & 2.0 \\
\hline
\end{tabular}

Once the waste forms had cooled, the waste form/beaker mass and distance from the top of the can to the waste form surface were recorded to allow calculation of the waste form volume and density. Similar measurements were also made prior to heating. The waste forms were removed from the cans by tapping the bottom and sides with a hammer and collecting the waste form fragments in a plastic bag. The fragments generated during the removal of the waste form from the cans were separated into four fractions. Following the initial experiment, an attempt was made to separate the waste form into fractions from the top, bottom, and middle of the can and a fourth composite fraction which consisted of material from all over the can. A $20 \mathrm{~g}$ sample of the waste form was taken from each fraction and prepared for the recoverability test by crushing the fragments to the required size $(+1 / 4$-in to $-3 / 8$-in) with a hammer. In the subsequent experiments, the waste form fragments were randomly segregated into four fraction from which $20 \mathrm{~g}$ samples were taken and prepared for the recoverability test.

\section{Results and Discussion}

The fabrication and testing data (masses of starting materials, processing conditions, and recoverability test) for each waste form are summarized in Appendix B. The appearance of the waste forms fabricated during the full-scale tests differed little from the smaller scale waste forms of similar composition. Figure 7 shows a photograph of waste form FS-1 prior to removal from the stainless steel can. The distortion of the can seen in the photograph was due to uneven heating provided by the furnace elements which are located on opposite walls of the furnace. The exposed surface of the waste forms were typically glazed by a thin layer of glass where most of the graphite burned away during the fabrication process. During the heating cycle 35-45\% shrinkage in the waste form thickness occurred in all experiments leaving significant freeboard in the stainless steel can. The waste forms also shrank away from the can wall as the glass frit slumped and the waste form densified. The mechanical strength of all the waste forms was very good. An extensive amount of hammering was required to remove the waste forms from the cans. The intensity of the hammer blows shattered the waste forms, resulting in a significant amount of fines and waste form fragments (with the largest dimension) ranging in size from less than 1-mm to approximately $100-\mathrm{mm}$. A photograph of fragments generated during the removal of waste form FS-1 from the stainless can is shown on Figure 8. 
The recoverability tests (see Appendix A) performed on samples of each waste form are summarized in Table 10. The filtrate samples generated during the tests were analyzed for cerium by ICP-ES.

Table 10 Recoverability Test Results from Full-scale Experiments

\begin{tabular}{cccc}
\hline $\begin{array}{c}\text { Run } \\
\text { Number }\end{array}$ & $\begin{array}{c}\text { Centerline } \\
\text { Temperature }\end{array}$ & $\begin{array}{c}\text { Heating } \\
\text { Time }\end{array}$ & $\begin{array}{c}\text { Cerium } \\
\text { Recoverability } \\
\text { Test }\end{array}$ \\
\hline FS-1/1 & 700 & 0.5 & 4.21 \\
FS-1/2 & & & 4.84 \\
FS-1/3 & & & 4.98 \\
FS-1/4 & & & 3.88 \\
FS-2/1 & 700 & 0.5 & 3.87 \\
FS-2/2 & & & 3.65 \\
FS-2/3 & & & 3.54 \\
FS-2/4 & & & 3.36 \\
FS-3/1 & 700 & 0.5 & 7.51 \\
FS-3/2 & & & 9.58 \\
FS-3/3 & & & 9.36 \\
FS-3/4 & & & 8.84 \\
FS-4/1 & 700 & 0.5 & 4.49 \\
FS-4/2 & & & 4.66 \\
FS-4/3 & & & 5.22 \\
FS-4/4 & & & 5.72 \\
FS-5/1 & 700 & 0.5 & 7.92 \\
FS-5/2 & & & 9.99 \\
FS-5/3 & & & 11.55 \\
FS-5/4 & & & 10.93 \\
\hline
\end{tabular}

In general, the recovery of cerium from the full-scale waste forms was higher than for smaller-scale experiments performed using the same simulated graphite fines composition and fabrication conditions. During the feasibility and $\mathrm{CaF}_{2}$ variability studies, the cerium recovery was always less than $4 \mathrm{~g} / \mathrm{kg}$ waste form (see Tables 2 and 4). Surprisingly, the addition of $\mathrm{CaF}_{2}$ to the simulated graphite fines resulted in the recovery of much higher levels of cerium during the recoverability tests. In contrast, the recovery of cerium from the $500 \mathrm{~g}$ scale waste forms fabricated during the $\mathrm{CaF}_{2}$ variability study decreased at high levels $(50 \mathrm{wt} \%)$ of $\mathrm{CaF}_{2}$ in the simulated graphite fines (see Table 4). An increased recovery of cerium from waste forms with high levels of $\mathrm{CaF}_{2}$ was also seen in the $125 \mathrm{~g}$ scale waste forms fabricated at temperatures above $700^{\circ} \mathrm{C}$ during the heating cycle studies (see Table 7). The increased recovery was attributed to the interaction of $\mathrm{CaF}_{2}$ with the glass frit as the frit nears a liquid state. However, samples of the waste forms from Runs FS-2 and FS-5 were examined by x-ray diffraction and showed no crystalline phases generated by alteration of the glass frit which could reduce the resistance to dissolution. Another possible explanation for the increased cerium recovery with increased 


\section{WSRC-TR-98-00380}

Revision 0

levels of $\mathrm{CaF}_{2}$ could be the development of amorphous phase separation induced by high levels of fluoride. Reaction between the NBS glass frit and $\mathrm{CaF}_{2}$ was evident from the EDX analysis of region 4 of the photomicrograph shown on Figure 1. This reaction produced a glassy phase in which sodium, aluminum, silicon, zirconium, (frit components) and calcium were detected. The effect of amorphous phase separation on durability depends upon the developing microstructure. [4] Assuming a Type B microstructure develops (i.e. the more durable phase (silicon-rich) is dispersed as discrete droplets in a continuous matrix of a less durable phase (boron-rich)), dramatic reductions in glass durability can result. If cerium partitions with the less durable phase, then higher levels of cerium recovery would be observed. However, the EDX analysis of region 4 did not show the presence of cerium in the glassy phase. If amorphous phase separation does play a role, the higher levels of cerium recovery may strictly be the result of a low durability waste form controlled by the development of the glassy phase regardless of cerium partitioning. 


\section{Immobilization of Actual Graphite Fines}

\section{Experimental Procedures}

Four graphite fines waste forms were fabricated using actual graphite fines from LANL to demonstrate optimal conditions established during the nonradioactive experiments. The material was sent from LANL due to problems in shipping graphite fines from Rocky Flats. Three cans containing nominally $300 \mathrm{~g}$ of graphite fines each were shipped from LANL. The plutonium assay for each can was $15 \mathrm{~g}$. The presence of $\mathrm{CaF}_{2}$ in the graphite fines could not be confirmed by LANL.

Since detailed information concerning the actual graphite fines composition was not know, a sample was removed from can MAG22R1 for characterization. Approximately $6.5 \mathrm{~g}$ of graphite fines were transferred to a $50 \mathrm{ml}$ glazed alumina crucible. The crucible was heated at $600^{\circ} \mathrm{C}$ until a constant mass was achieved. The total heating time was approximately $10 \mathrm{hr}$. The residue from the crucible was transferred to a $150 \mathrm{ml}$ beaker and dissolved using approximately $50 \mathrm{ml}$ of $15.7 \mathrm{M}$ nitric acid/0.1M potassium fluoride. The beaker was heated near the boiling point (approximately $110^{\circ} \mathrm{C}$ ) and stirred for approximately $4 \mathrm{hr}$ during the dissolution. The beaker contents were filtered using a piece of $0.45 \mu \mathrm{m}$ paper. The filter paper and collected solids were then dissolved using approximately $25 \mathrm{ml}$ of fresh dissolver solution. The beaker and contents were heated and stirred in the same manner as the initial dissolution for 2 hr. Very few solids were collected during the filtration and were assumed to contain no plutonium. The filtrates from the two dissolutions were combined and sampled. The sample was analyzed for plutonium using liquid scintillation counting and a gamma scan and for other elements of interest using ICP-ES.

Four $500 \mathrm{~g}$ waste forms were fabricated using the actual graphite fines residues received from LANL. In each experiment, nominally $100 \mathrm{~g}$ of graphite fines were mixed with enough glass frit to achieve a 4:1 frit to residue ratio. The same NBS frit used in the nonradioactive studies was used for the waste form fabrications. The composition of the graphite fines was altered in two of the experiments. In one waste form, $15 \mathrm{wt} \% \mathrm{CaF}_{2}$ was added to the residue to measure the impact on plutonium recovery. In a second waste form, $6 \mathrm{wt} \% \mathrm{CeO}_{2}$ was added to the residue so a comparison of the recovery of cerium and plutonium could be made following the recoverability test. All waste forms were heated at $700^{\circ} \mathrm{C}$ for $2 \mathrm{hr}$, except for one which was heated for only $0.5 \mathrm{hr}$ to validate the heating cycle studies which demonstrated that a $0.5 \mathrm{hr}$ heating time was adequate to achieve a cerium recovery of less than $4 \mathrm{~g} / \mathrm{kg}$ waste form.

The waste forms were fabricated using the same techniques as described for the nonradioactive experiments. The desired amounts of frit, $\mathrm{CaF}_{2}$, and $\mathrm{CeO}_{2}$ were premeasured into a $1 l$ plastic bottle. The bottles were placed in the glovebox and the desired amount of graphite fines added. Waste forms RM-1, RM-2, and RM-3 were fabricated from graphite fines taken from can MAG22R1. Graphite fines taken from can MAG22R2 were used to fabricate waste form RM-4. The plastic bottles were shaken to thoroughly mix the waste form components and the contents transferred to a $10.4-\mathrm{cm}$ diameter by $13.1-\mathrm{cm}$ tall stainless steel beaker. The waste forms were heated using an Applied Test Systems, Inc, elevator furnace installed in a glovebox. A furnace setpoint of $700^{\circ} \mathrm{C}$ was used for each experiment. The furnace controller was programmed to 
ramp the temperature to the setpoint in $20 \mathrm{~min}$. The furnace typically overshot the setpoint by approximately $10^{\circ} \mathrm{C}$; however, the fabrication temperature was re-established within approximately $1 \mathrm{~min}$. The furnace temperature was maintained at $700^{\circ} \mathrm{C}$ until the end of the heating time was reached. At this point, the power to the furnace elements was turned off and the waste form lowered from the furnace and allowed to cool. The waste from compositions and fabrication conditions for the experiments are summarized in Table 11.

Table 11 Fabrication of Actual Graphite Fines Waste Forms

\begin{tabular}{|c|c|c|c|c|c|c|}
\hline \multirow{2}{*}{$\begin{array}{c}\text { Run } \\
\text { Number }\end{array}$} & \multicolumn{4}{|c|}{ Waste Form Composition } & \multirow{2}{*}{$\begin{array}{c}\text { Fabrication } \\
\text { Temperature } \\
\left({ }^{\circ} \mathrm{C}\right)\end{array}$} & \multirow{2}{*}{$\begin{array}{c}\text { Heating } \\
\text { Time } \\
\text { (hr) }\end{array}$} \\
\hline & $\begin{array}{c}\text { Graphite } \\
\text { Fines } \\
\text { (wt\%) }\end{array}$ & $\begin{array}{l}\mathrm{CaF}_{2} \\
(\mathrm{wt} \%) \\
\end{array}$ & $\mathrm{CeO}_{2}$ & $\begin{array}{l}\text { Glass } \\
\text { Frit } \\
(w t \%)\end{array}$ & & \\
\hline RM-1 & 20 & 0 & 0 & 80 & 700 & 0.5 \\
\hline RM-2 & 20 & 0 & 0 & 80 & 700 & 2.0 \\
\hline RM-3 & 20 & 0 & 1 & 79 & 700 & 2.0 \\
\hline RM-4 & 17 & 3 & 0 & 80 & 700 & 2.0 \\
\hline
\end{tabular}

Once the waste forms were cool, the distance from the top of the beaker to the waste form surface was recorded. A similar measurement was also made prior to heating. These measurements were used with the beaker geometry and estimates of the mass of the waste form before and after heating to calculate the change in density. The capacity of the analytical balance available in the glovebox would not allow measuring the mass of the beaker and waste form before or after heating. The sum of the starting material masses was used to calculate the initial density. The final mass of the waste form was estimated by assuming the loss of $7 \mathrm{~g}$ of material from the beaker during the heating cycle. This value was based on the loss of mass during the fabrication of similar waste forms during the feasibility and $\mathrm{CaF}_{2}$ variability studies (see Tables B.3 and B.7 in Appendix B).

The waste forms were removed from the beakers by tapping the bottom and sides with a hammer and collecting the fragments in a plastic bag. Once the waste form was removed from the beaker, a $20 \mathrm{~g}$ sample was prepared for the recoverability test by crushing with a hammer to the required size distribution (+1/4-in to-3/8-in fragments). The recoverability tests were performed using the procedure given in Appendix A.

\section{$\underline{\text { Results and Discussion }}$}

The results from the characterization of the graphitc fines residues are summarized in Table 12. To calculate the composition from the elemental analyses, all the components except calcium were assumed to be present as oxides, all the calcium was assumed to be $\mathrm{CaF}_{2}$, and the balance of the sample mass was assumed to be graphite. The measured plutonium concentration (nominally $6 \mathrm{wt} \%$ ) is consistent with the value assigned to each can by LANL. The amount of graphite is approximately the same as the average value for the material stored at Rocky Flats. Although the $\mathrm{CaF}_{2}$ and $\mathrm{PuO}_{2}$ are slightly lower than the average Rocky Flats concentrations, the material from LANL would appear to be fairly representative of the material stored at Rocky Flats. 
Table 12 Composition of Graphite Fines Residue

\begin{tabular}{cc}
\hline \hline Component & $\begin{array}{c}\text { Composition } \\
\text { (wt\%) }\end{array}$ \\
\hline $\mathrm{Al}_{2} \mathrm{O}_{3}$ & 0.4 \\
$\mathrm{~B}_{2} \mathrm{O}_{3}$ & 0.3 \\
$\mathrm{C}$ & 74.6 \\
$\mathrm{CaF}_{2}$ & 8.7 \\
$\mathrm{Fe}_{2} \mathrm{O}_{3}$ & 0.6 \\
$\mathrm{MgO}$ & 7.1 \\
$\mathrm{Na}_{2} \mathrm{O}$ & 1.0 \\
$\mathrm{PuO}_{2}$ & 7.1 \\
$\mathrm{SiO}_{2}$ & 0.2 \\
\hline
\end{tabular}

The fabrication and testing data (masses of starting materials, processing conditions, and recoverability test) for each waste form are summarized in Appendix B. All the waste forms produced from the actual graphite fines looked like hard and compact disks prior to removal from the stainless steel beakers. The waste forms fabricated without the addition of $\mathrm{CaF}_{2}$ receded from the wall of the can leaving a $3-5 \mathrm{~mm}$ void similar to the waste forms fabricated without $\mathrm{CaF}_{2}$ during the heating cycle study. A photograph of the waste form fabricated during Run RM-3 is shown on Figure 9. Waste form RM-4, which contained $15 \mathrm{wt} \% \mathrm{CaF}_{2}$ added to the graphite fines, had an appearance similar to the waste forms fabricated with high levels of $\mathrm{CaF}_{2}$ during the heating cycle studies. The waste form extended all the way to the wall of the beaker and the surface was smooth with a glazed appearance.

When the waste form fabricated during Run RM-1 was removed from the beaker, unconsolidated powder was present at the bottom. With actual graphite fines, it appears that a $0.5 \mathrm{hr}$ heating time is not adequate to fully fuse the waste form. No powder was seen in the beakers from any of the other experiments. The waste forms fabricated in these experiments were also very difficult to remove from the beakers. The force of the hammer blows to the bottom and side of the beakers generated powdered fines and fragments (with the largest dimension) ranging in size from less than 1-mm to approximately $50-\mathrm{mm}$. A photograph of waste form RM-3 following removal from the stainless steel beaker is shown on Figure 10. Plutonium recoverability tests were performed using $20 \mathrm{~g}$ samples from each waste forms. The samples were prepared by crushing the fragments with a hammer to the required size ( $+1 / 4$-in to $-3 / 8$-in). When fragments from waste form RM-1 were struck with the hammer, they disintegrated into a powder with a particle size not much different than the actual graphite fines. The recoverability test was performed using a $20 \mathrm{~g}$ sample of the powdered material to assess the resistance to dissolution of diluted graphite fines. The recoverability tests for each waste form are summarized in Table 12 . The filtrate samples generated during the tests were analyzed for plutonium using liquid scintillation counting and gamma scans. The cerium analysis for Run RM-3 was performed by ICP-ES. 
Table 13 Recoverability Tests for Actual Graphite Fines Waste Forms

\begin{tabular}{ccc}
\hline Run Number & $\begin{array}{c}\text { Plutonium Recovery (Pu) } \\
\text { (g Pu/kg Waste Form) }\end{array}$ & $\begin{array}{c}\text { Cerium Recovery (Ce) } \\
\text { (g Ce/kg Waste Form) }\end{array}$ \\
\hline RM-1 & 7.7 & N/A \\
RM-2 & 4.5 & N/A \\
RM-3 & 3.9 & 1.8 \\
RM-4 & 3.2 & N/A \\
\hline
\end{tabular}

Although the results from the plutonium recoverability tests demonstrated that the waste form fabrication conditions were not adequate to insure that plutonium recoveries are always less than $4 \mathrm{~g} / \mathrm{kg}$ waste form, the results were encouraging. The plutonium recovery from the three waste forms fabricated with a $2 \mathrm{hr}$ heating time were below or near the Rocky Flats product specification. Uncertainties in the plutonium from the recoverability test would make these values difficult to distinguish from $4 \mathrm{~g} / \mathrm{kg}$ waste form at reasonable confidence levels. Therefore, with a slight improvement in the fabrication conditions, such as a small increase in the frit to residue ratio, waste forms fabricated at this scale would almost certainly meet Rocky Flats product specification.

The failure of waste form RM-1 to pass the recoverability test is not surprising given the fact that the glass frit/residue mixture did not fuse during the fabrication process. The dissolution of the plutonium was enhanced due to the increased surface area provided by the small particles. Even though the remaining waste forms passed or nearly passed the recoverability test, the mechanical durability of the fragments used in the test was severely damaged. Following the test, the fragments were easily crushed with a spatula. The decrease in the structural integrity and exposure of additional surface area contributes to increased plutonium dissolution. A small increase in the frit to residue ratio is likely the key to improving the mechanical durability of the waste forms and retard the $\mathrm{PuO}_{2}$ dissolution.

The addition of $15 \mathrm{wt} \% \mathrm{CaF}_{2}$ to the graphite fines may have slightly reduced the recovery of plutonium from waste form RM-4, which is consistent with nonradioactive waste forms fabricated during the $\mathrm{CaF}_{2}$ variability study (see Table 4). The impact of increasing concentrations of $\mathrm{CaF}_{2}$ on the plutonium recoverability from full-scale waste forms is an important issue which was not analyzed during this study. Before implementation of the graphite fines immobilization process on a production scale, the recovery of plutonium from actual fullscale waste forms should be measured for the range of $\mathrm{CaF}_{2}$ concentrations. The recovery of cerium from the full-scale nonradioactive waste forms increased dramatically when the $\mathrm{CaF}_{2}$ concentration increased from 0 to $15 \mathrm{wt} \%$ (see previous section). The possibility of the real waste forms exhibiting this behavior should be examined.

The cerium recovery from waste form RM-3 was less than expected. The recovery of cerium from nonradioactive waste forms fabricated using similar conditions was approximately twice this value (see Tables 2 and 5). The discrepancy is not understood. Potentially, the low value could be attributed to problems with the cerium analysis. The graphite fines matrix is somewhat different than the simulated matrix which may have potentially biased the analysis low. 


\section{Furnace Offgas Characterization}

\section{Experimental Procedures}

The immobilization of actual graphite fines will be performed by mixing the residue with a glass frit and heating in a furnace to nominally $700^{\circ} \mathrm{C}$. At this temperature, the potential exists for a small amount of the graphite to burn. In an oxidizing atmosphere, the combustion product should be carbon dioxide $\left(\mathrm{CO}_{2}\right)$; however, under reducing conditions, carbon monoxide (CO) may form. Carbon monoxide forms explosive mixtures with air from 12.5 to 74.2 vol\%. [5] To understand the potential for the formation of $\mathrm{CO}$ during the immobilization process, a series of experiments was performed during which the offgas from a purged furnace was analyzed.

The furnace proposed for the graphite fines immobilization process at Rocky Flats contains a $0.03 \mathrm{~m}^{3}\left(1 \mathrm{ft}^{3}\right)$ furnace cavity. During the immobilization process, Rocky Flats proposes to purge the furnace with $0.006 \mathrm{~m}^{3} / \mathrm{min}\left(0.2 \mathrm{ft}^{3} / \mathrm{min}\right)$ of air $\left(\right.$ at $\left.25^{\circ} \mathrm{C}, 1 \mathrm{~atm}\right)$. A $20.3-\mathrm{cm}$ diameter by 25.4-cm tall ( 8 -in by 10 -in) stainless steel can was proposed for use during the immobilization process when this series of experiments were performed. These equipment and processing constraints were used to design scaled experiments utilizing a CM, Inc. Rapid Temp Furnace TM with a nominal $15.2-\mathrm{cm}$ wide by $15.2 \mathrm{-cm}$ tall by 15.2 -cm deep ( 6 -in by 6 -in by 6 -in) furnace cavity. The furnace was purged with air using a calibrated rotameter to control the flowrate at the desired value. The offgas from the furnace was routed through a $1 l$ filtering flask which was fitted with a rubber stopper. A piece of Tygon ${ }^{\mathrm{TM}}$ tubing inserted through the rubber stopper was used as a connection point for a $50 \mathrm{ml}$ gas sampling syringe. The offgas was allowed to exit through the side connection to the filtering flask. The air flowrate through the furnace was scaled using the residence time of the empty Rocky Flats furnace. An empty furnace provided a conservative bound for the experiments since this method of scaling results in a slower air flowrate (compared to a loaded furnace) which favors the formation of $\mathrm{CO}$.

A 10.2 -cm diameter by 6.4 -cm tall (4-in by 2.5 -in) beaker filled approximately 2 -in high with simulated frit/ residue mixtures $(300 \mathrm{~g})$ was used in all experiments. The short can was necessary due to a thermocouple obstruction in the furnace which limited the height of the beaker to approximately $7.6-\mathrm{cm}(3-\mathrm{in})$. The amount and geometry of the simulated material provides a conservative bound for the production of $\mathrm{CO}$ in the experiments based on either a comparison of the surface area to volume ratio of the full-scale can or the surface area to free furnace volume. Both comparisons are based on the assumption that the surface area of the graphite fines which is exposed to the furnace atmosphere is the important scaling factor.

The experimental matrix for the offgas characterization studies is shown in Table 14. Initially, an experiment was performed without fabricating a waste form to establish baseline conditions for the offgas analysis. Subsequent experiments were performed using $300 \mathrm{~g}$ of simulated frit/residue mixtures. The simulated residue in experiments $1-6$ was $100 \%$ graphite powder to maximize production of $\mathrm{CO}$. Experiment 7 was performed using a simulated graphite fines composition of $38 \mathrm{wt} \%$ graphite, $50 \mathrm{wt} \% \mathrm{CaF}_{2}$, and $12 \mathrm{wt} \% \mathrm{CeO}_{2}$ to understand the impact of high $\mathrm{CaF}_{2}$ concentrations on the offgas composition. The frit to residue ratio for all experiments was maintained at $4: 1$. The waste forms were fabricated at 700 and $900^{\circ} \mathrm{C}$ to bracket any potential operating range. For each temperature, the air purge was set at $1 / 10,1$, and 10 times the 
value scaled from the Rocky Flats equipment and operating conditions (0.04 SCMH or 1.4 SCFH). The heating time for all experiments was $2 \mathrm{hr}$.

Table 14 Offgas Characterization Experiments

\begin{tabular}{ccc}
\hline \hline Run Number & $\begin{array}{c}\text { Air Flow Rate } \\
(\mathrm{SCMH})\end{array}$ & $\begin{array}{c}\text { Temperature } \\
\left({ }^{\circ} \mathrm{C}\right)\end{array}$ \\
\hline Baseline & 0.04 & 700 \\
1 & 0.04 & 700 \\
2 & $1 / 10 \times 0.04$ & 700 \\
3 & $10 \times 0.04$ & 700 \\
4 & 0.04 & 900 \\
5 & $1 / 10 \times 0.04$ & 900 \\
6 & $10 \times 0.04$ & 900 \\
7 & 0.04 & 900 \\
\hline
\end{tabular}

The waste forms were fabricated used the same techniques as described for the other experiments. The desired amounts of frit, $\mathrm{CaF}_{2}$ and $\mathrm{CeO}_{2}$ were measured into a $1 l$ plastic bottle. The graphite powder and NBS glass frit used in the experiments were supplied by Rocky Flats. The waste form components were mixed by shaking the bottle and transferred to the stainless steel beaker. The beaker was sealed inside the furnace and the desired air purge established. The furnace controller was programmed to step the temperature to the desired setpoint. Approximately $10 \mathrm{~min}$ were required for the furnace temperature to reach $700^{\circ} \mathrm{C}$; approximately $25 \mathrm{~min}$ were required to reach $900^{\circ} \mathrm{C}$. When the temperature reached the setpoint, the first gas sample was taken by attaching a $50 \mathrm{ml}$ gas syringe to the Tygon ${ }^{\mathrm{TM}}$ tubing inserted into the filtering flask. The sample was slowly withdrawn (over 30 to $60 \mathrm{sec}$ ) into the syringe. Six additional gas samples (one every $20 \mathrm{~min}$ ) were taken over the course of the experiment using the same procedure. The syringes were valved close and capped until the gas was analyzed. The gas samples were analyzed for $\mathrm{CO}, \mathrm{CO}_{2}$, and oxygen $\left(\mathrm{O}_{2}\right)$ by gas chromatography. The overall uncertainty for the measurements was less than $\pm 25 \%$.

$\underline{\text { Results and Discussion }}$

The offgas analyses for each immobilization experiment are presented in Appendix C. In all cases the measured concentration of $\mathrm{CO}$ in the furnace offgas was much less than $1 \mathrm{vol} \%$; therefore, formation of explosive mixtures of $\mathrm{CO}$ is not a concern for the graphite fines immobilization process. In fact, it is doubtful whether a detectable concentration of $\mathrm{CO}$ will even be formed. In the experiment to establish baseline conditions and the first four waste form fabrication experiments, the concentration of $\mathrm{CO}$ was between 0.002 and $0.026 \mathrm{vol} \%$ (20 and $260 \mathrm{ppm}(\mathrm{v} / \mathrm{v}))$. When the next experiment was performed (Run Number 5) the concentration of $\mathrm{CO}$ in the furnace offgas peaked at $0.250 \mathrm{vol} \%(2500 \mathrm{ppm}(\mathrm{v} / \mathrm{v}))$. Prior to this experiment, the furnace was used to sinter a ceramic pellet containing a paraffin binder. Evidently the paraffin volatilized and contaminated the furnace chamber during the sintering process. Before using the furnace again, it was heated to $1500^{\circ} \mathrm{C}$ for $2 \mathrm{hr}$ with an air purge to remove any residual organic material. A second experiment was then performed (without fabricating a waste form) to establish a new baseline for the offgas analyses. The gas analyses from the second baseline and 
subsequent fabrications experiments did not show a CO concentration above the gas chromatograph detection limit. 


\section{Conclusions and Recommendations}

Although the development of an immobilization process for Rocky Flats graphite fines was not concluded, the experiments performed indicate microencapsulation with a glass frit to form an acceptable waste form is feasible. The correlation of nonradioactive experiments using simulated graphite fines and the fabrication of waste forms using actual materials from LANL was not exact; however, the results of the surrogate experiments can be generally applied. In the feasibility experiments, the decrease in the recovery of cerium from simulated waste forms as a function of the frit to residue ratio was demonstrated. A two-fold increase in the frit to residue ratio (4:1 to 8:1) resulted in approximately a factor of five decrease in the cerium recoverability. These results can be used to adjust the recovery of plutonium from actual waste forms to meet the Rocky Flats product acceptance specification.

The behavior of $\mathrm{CaF}_{2}$ during the fabrication of a graphite fines waste form is still not completely understood. The recovery of cerium from small-scale waste forms containing $50 \mathrm{wt} \% \mathrm{CaF}_{2}$ fabricated between 600 and $700^{\circ} \mathrm{C}$ using heating times of at least $0.5 \mathrm{hr}$ met the product specification while waste forms containing no $\mathrm{CaF}_{2}$ did not. The difference in durability was attributed to the fluxing ability of $\mathrm{CaF}_{2}$ which produced a denser waste form with less surface area and more resistance to dissolution. When fabrication temperatures above $700^{\circ} \mathrm{C}$ $\left(750-850^{\circ} \mathrm{C}\right)$ were used, the effect of $\mathrm{CaF}_{2}$ on the recovery of cerium from the waste form changed. Waste forms fabricated with at least a $0.5 \mathrm{hr}$ heating time which contained no $\mathrm{CaF}_{2}$ passed the recoverability test while the waste forms containing $50 \mathrm{wt} \%$ generally failed. The increase in cerium recovery from the $\mathrm{CaF}_{2}$-containing waste forms could be due to interaction with the glass frit as it nears a molten state; although, no direct evidence was seen. The deleterious effect of $\mathrm{CaF}_{2}$ on cerium recovery was also seen in full-scale waste forms fabricated using optimal conditions defined by the small-scale experiments. A continuation of this work must investigate this observation. The effect of varying concentrations of $\mathrm{CaF}_{2}$ in actual fullscale waste forms must be understood or a correlation between the performance of simulated waste forms demonstrated. It is expected that adjusting the frit to residue ratio and the time/temperature cycle will provide the flexibility to meet the Rocky Flats product specification.

Although the plutonium recoverability tests demonstrated that the process conditions used to fabricate the small-scale waste forms from actual graphite fines were insufficient to always meet the product specification, the results were encouraging. A 4:1 frit to residue ratio, a temperature of $700^{\circ} \mathrm{C}$, and a $2 \mathrm{hr}$ heating time produced waste forms with plutonium recoveries of $4 \pm 1 \mathrm{~g} / \mathrm{kg}$. With a slight increase in the frit to residue ratio, waste forms fabricated at this scale would certainly meet the Rocky Flats product specification. The scale-up of the waste form fabrication process to nominally $3 \mathrm{~kg}$ must be demonstrated. With a 5:1 to $6: 1$ frit to residue ratio, waste forms fabricated by maintaining a $700^{\circ} \mathrm{C}$ centerline temperature for $2 \mathrm{hr}$ should pass the plutonium recoverability test. A key part of this demonstration with be assessing the impact of varying concentration of $\mathrm{CaF}_{2}$ on the plutonium recoverability. 
WSRC-TR-98-00380

Revision 0

The small-scale experiments used to characterized the offgas from the immobilization process demonstrated that formation of an explosive CO/air mixture is not a concern. The highest concentration measured was much less than 1 vol\% and this peak concentration was attributed to organic contamination in the furnace generated by another research program. 


\section{Acknowledgments}

The assistance of James C. Marra and David K. Peeler during the performance of this work was greatly appreciated. Discussions involving the glass chemistry and interaction of the glass frit with the graphite fines residue was extremely helpful in developing and understanding the process. The assistance of Catherine R. (Kricket) Arbaugh and Karen Palmer during the fabrication of waste forms and performance of recoverability test was invaluable.

Funding for this investigation was made possible through support by the Nuclear Materials Stabilization Program Office, United States Department of Energy, Albuquerque Operations and Headquarters Offices, under the auspices of the DNFSB 94-1 Research and Development Project. 


\section{References}

1. J. T. Conway, "Recommendation 94-1 to the Secretary of Energy pursuant to 42 U.S.C. [paragraph] 2286a(5) Atomic Energy Act of 1954, as amended" (Attachment), Letter from Defense Nuclear Facilities Safety Board to Secretary of Energy, Washington, DC (1994).

2. Memo, from Edward J. McCallum, Director, Office of Safeguards and Security, NN-51, to Distribution, "Additional Attractiveness Level E Criteria for Special Nuclear Material," dated July 22, 1996.

3. J. D. Vienna, H. Li, J. G. Darab, P. Hrma, J. K. Luey, and M. L. Elliott, Frit Screening and Selection for Rocky Flats Ash and Sand, Slag, and Crucible Vitrification, Report No. PNNL 11591, Pacific Northwest National Laboratory, Richland, WA (1997).

4. M. Tomozawa, in Treatise on Material Science and Technology, Vol. 17, edited by M. Tomozawa and R. H. Doremus (Academic Press, New York, 1972), pp. 71-113.

5. J. A. Dean, Lange's Handbook of Chemistry, $14^{\text {th }}$ Edition, McGraw-Hill, Inc., New York, NY (1992). 
Figure 1 Photomicrograph of Waste Form 10a

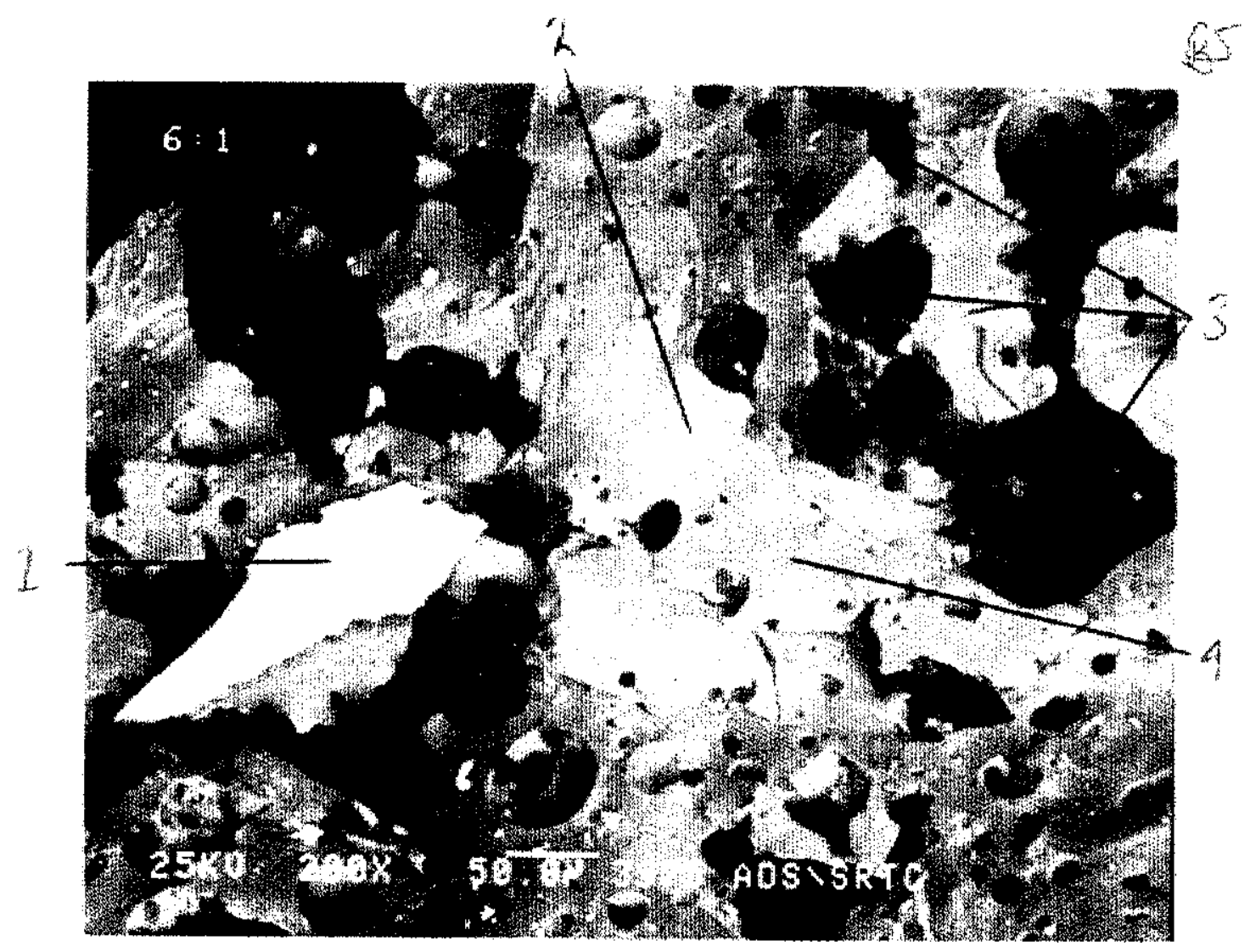


Figure 2 Cerium Recovery from Graphite Fines Waste Forms

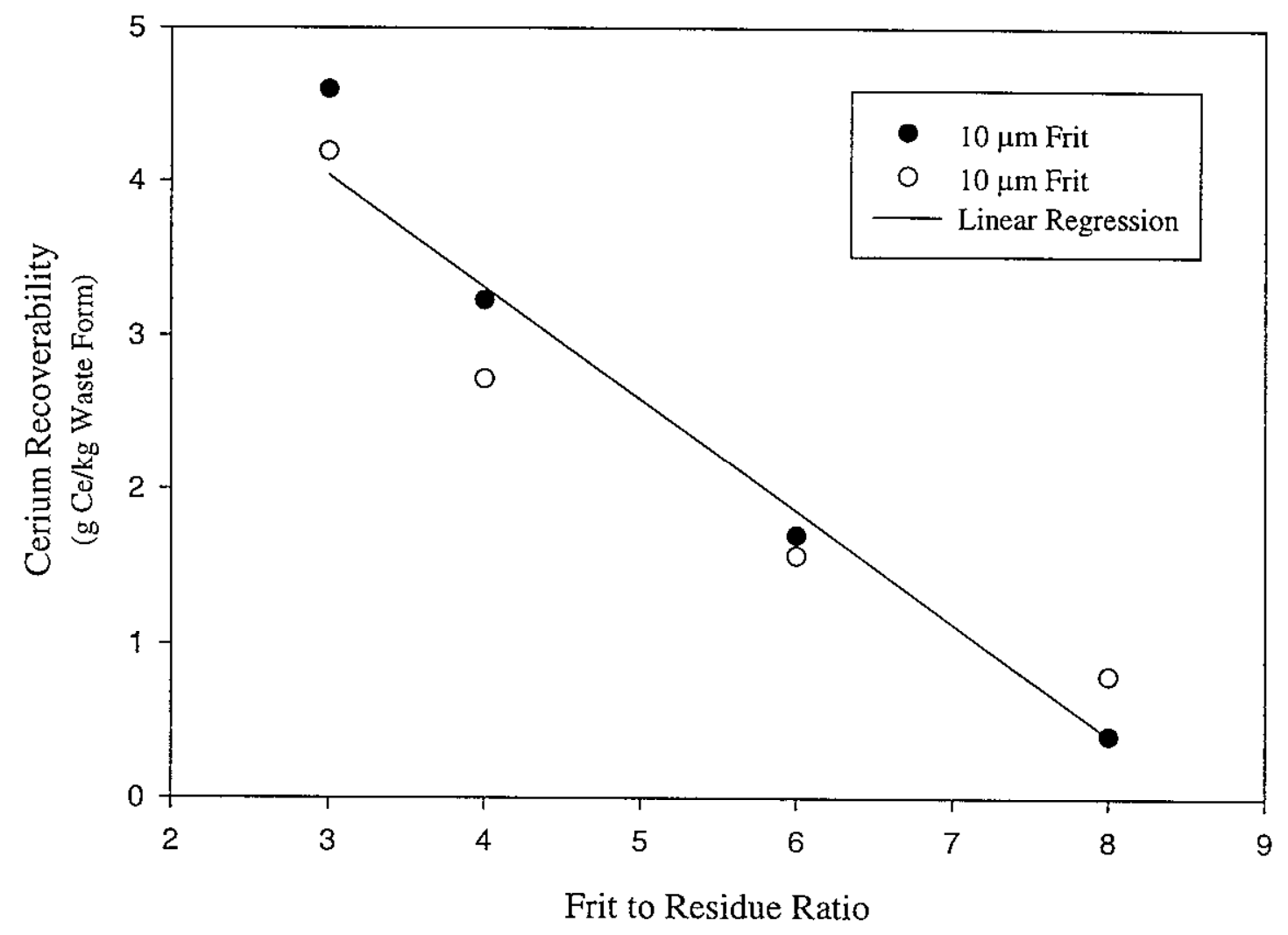


Figure 3 Typical Waste Form Containing $\mathrm{No} \mathrm{CaF}_{2}$

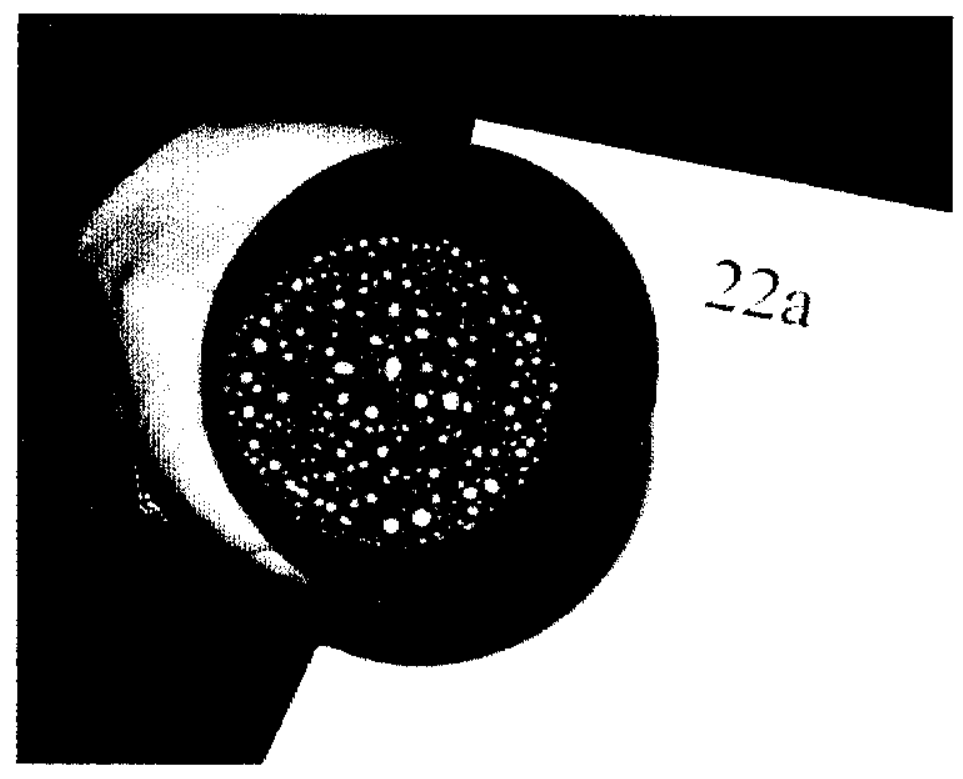

Figure 4 Typical Waste Form with High $\mathrm{CaF}_{2}$

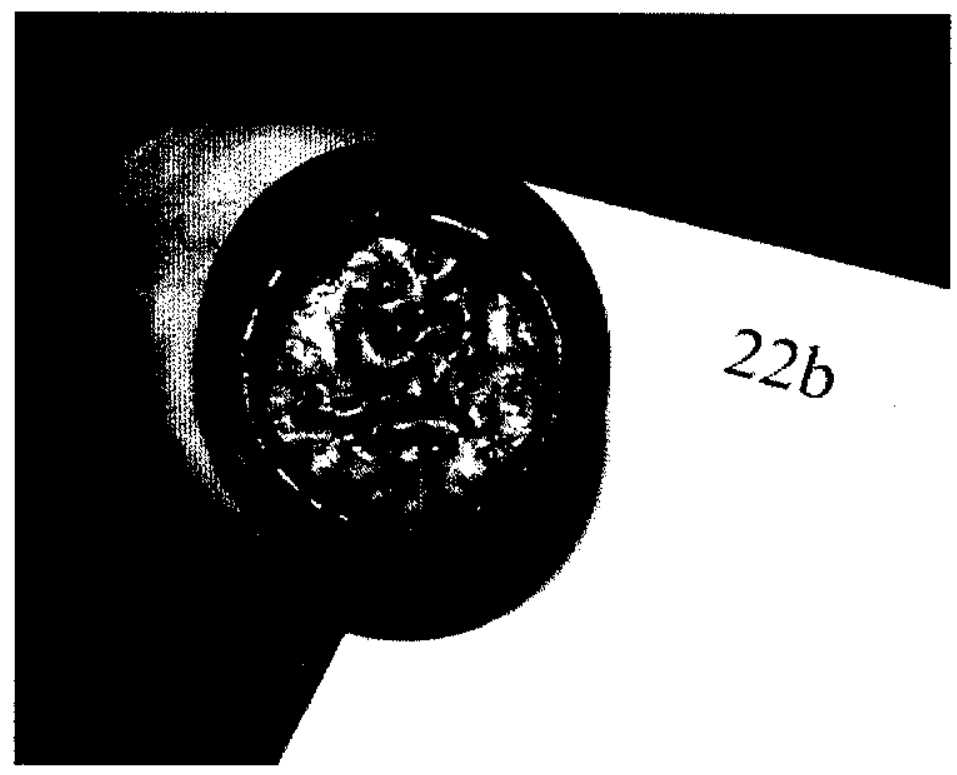


Figure 5 Cerium Recovery from Graphite Fines Waste Forms

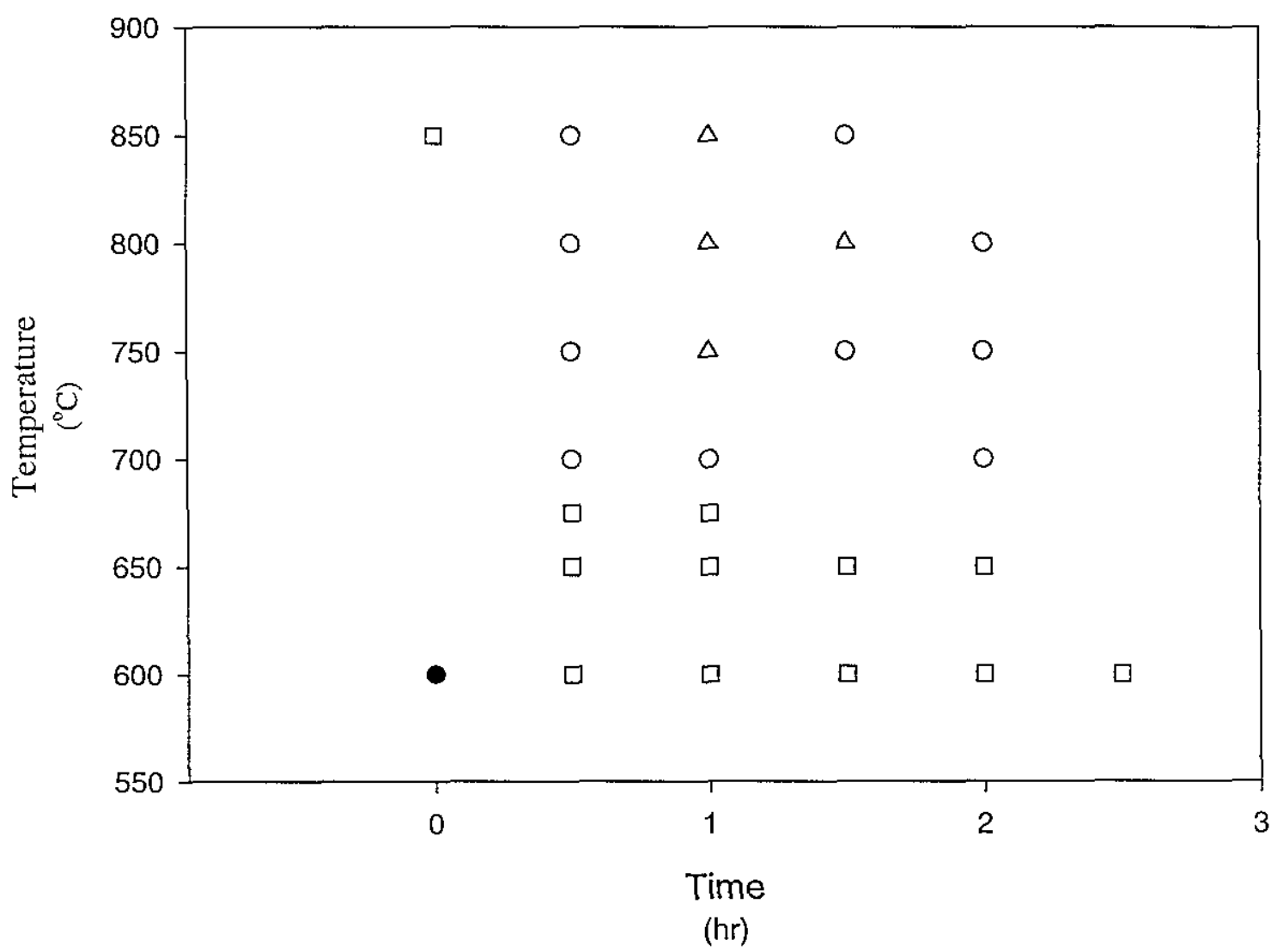

$\begin{array}{llll}- & \text { Both Samples Failed } & \square & \text { Sample Containing } \mathrm{CaF}_{2} \text { Passed } \\ \circ & \text { Both Samples Passed } & \triangle & \text { Sample Without } \mathrm{CaF}_{2} \text { Passed }\end{array}$


WSRC-TR-98-00380

Revision 0

Figure 6 Centerline Temperature Profile for Run FS-2

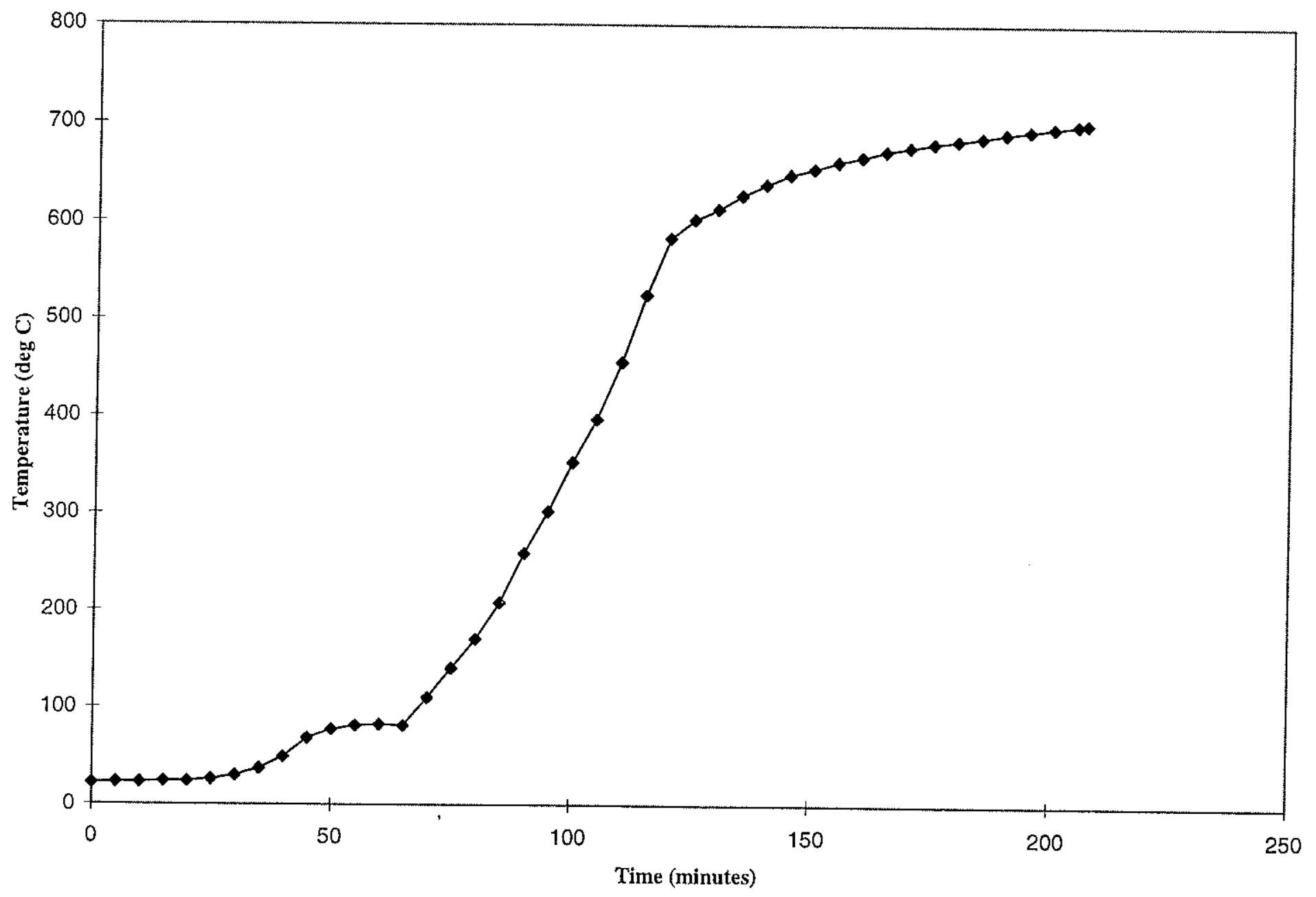


WSRC-TR-98-00380

Revision 0

Figure 7 Full-scale Graphite Fines Waste Form

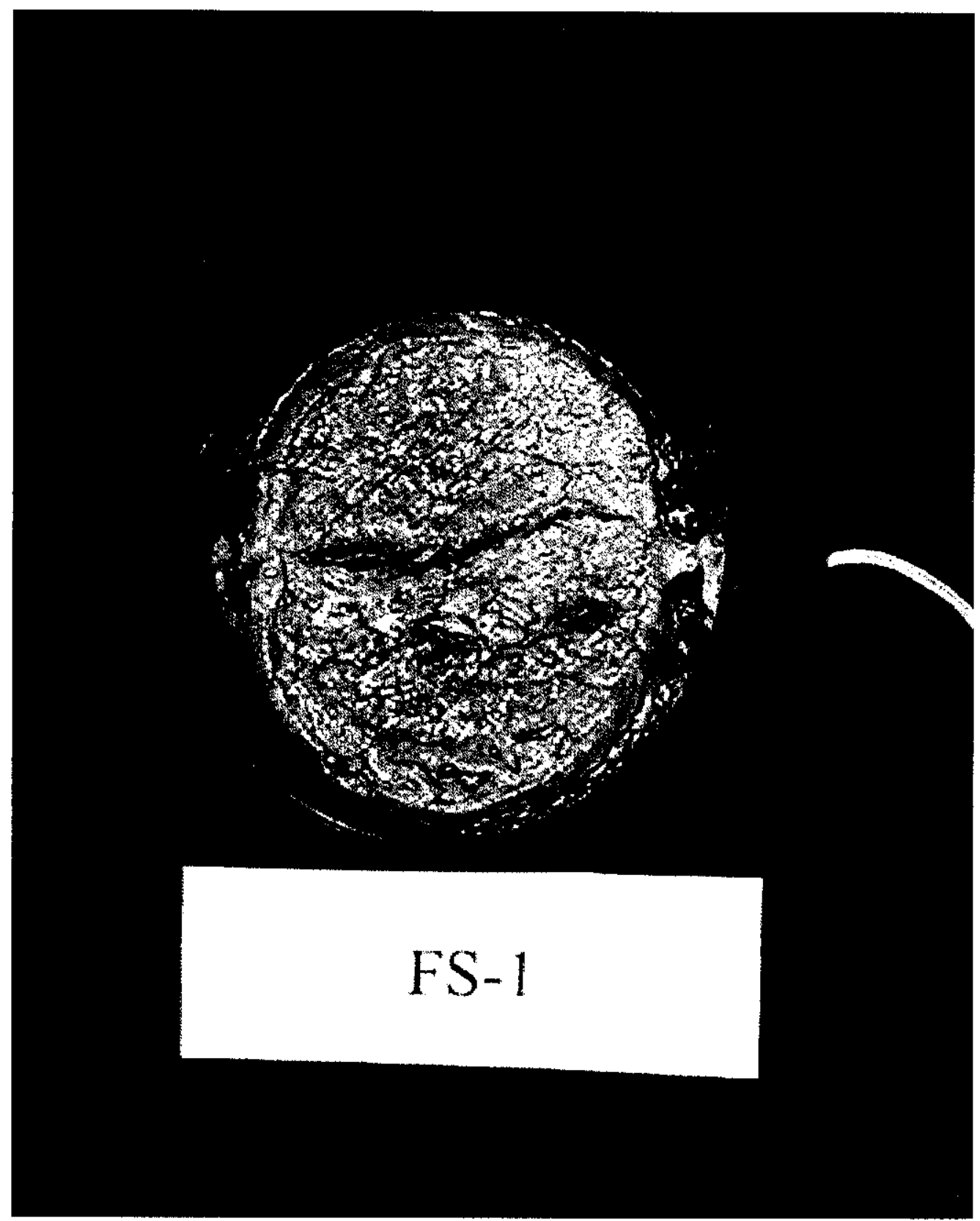


Figure 8 Fragments from Waste Form FS-1

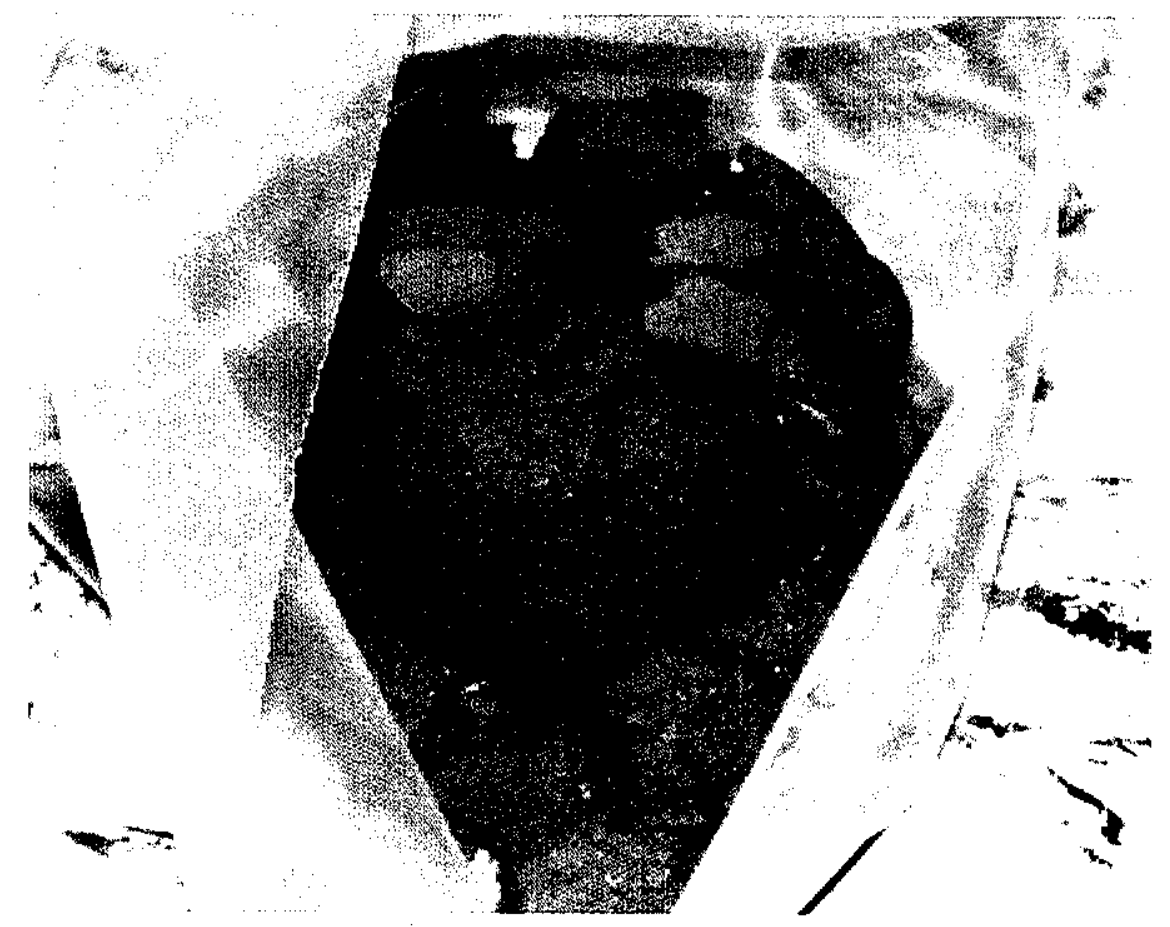


Figure 9 Actual Graphite Fines Waste Form (RM-3)

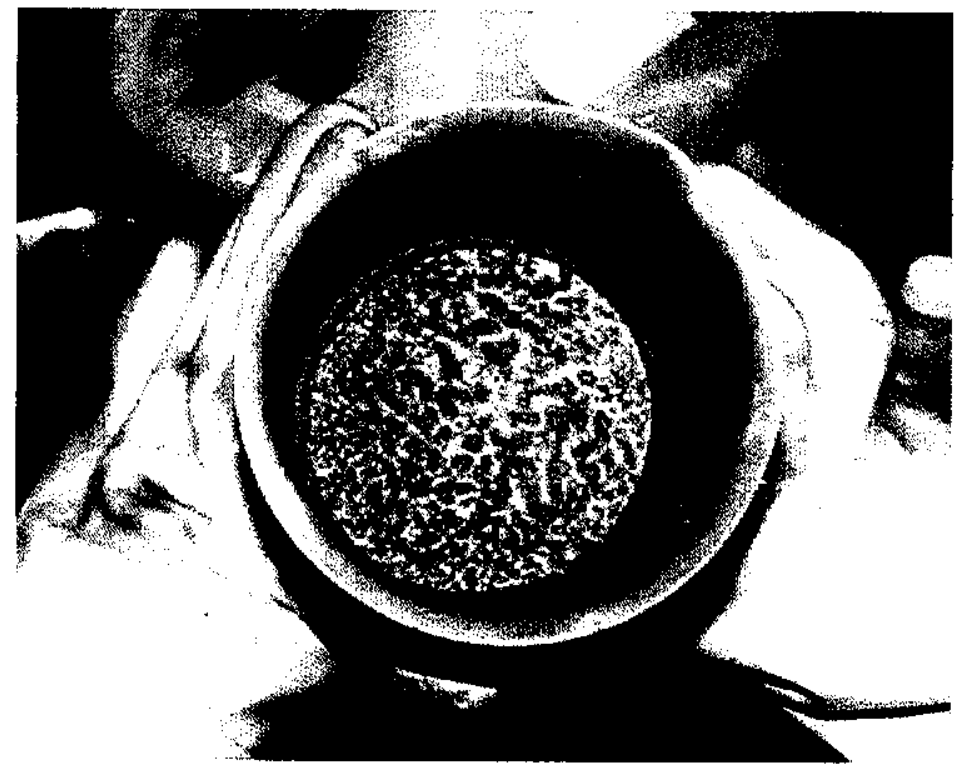

Figure 10 Fragments from Actual Graphite Fines Waste Form (RM-3)

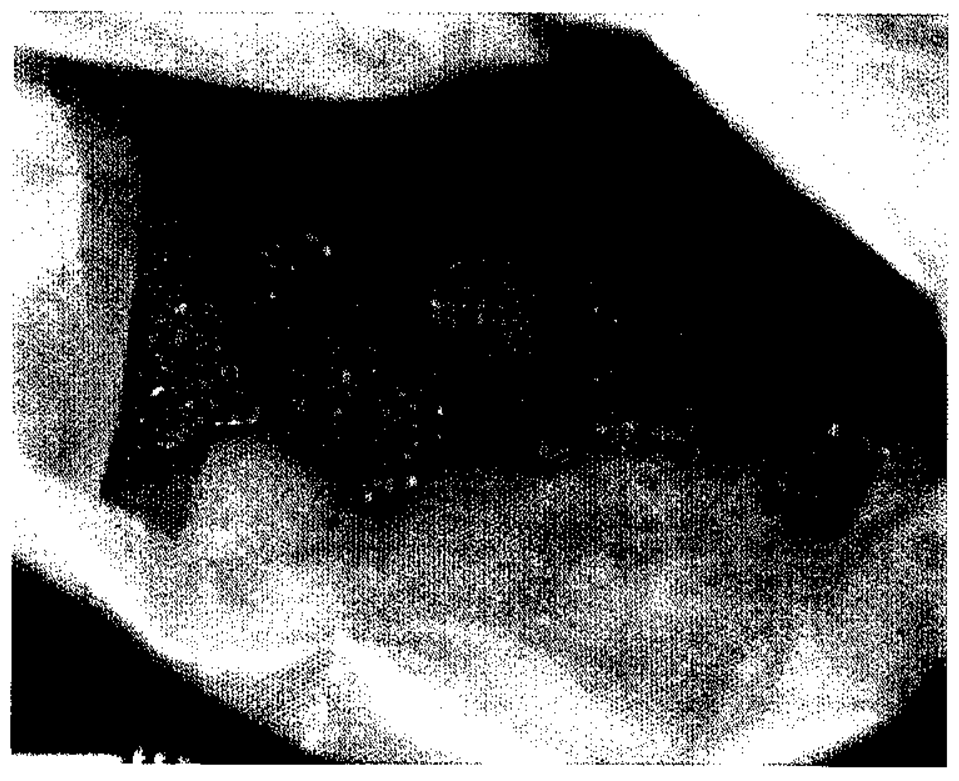




\section{Appendix A: Plutonium Recoverability Testing}

(Version $3.1-11 / 3 / 97)$

This test is intended to provide a standardized method for comparing ease of plutonium recovery from wastes amenable to nitric acid dissolution or leach. The procedure is based on the historical method of recovering Plutonium from ash at Rocky Flats. ${ }^{1}$ For refractory matrices to be qualified as practically irrecoverable, the extraction procedure should yield a quantity of plutonium that does not exceed that specified in Table A.1, Column 3 . This test is specifically designed to be used during the Demonstration and Testing phase of process development, to validate processing parameters. It is not intended to be used on every product run coming out of an implemented process. Once a process is validated, normal quality assurance processes, to assure that the process remains within the parameter range validated in the D\&T phase is all that is required. Samples to be run through this test will not contain more than $5 \mathrm{wt} \%$ plutonium. Successful passage of the recoverability test by samples containing $>5 \mathrm{wt} \%$ Plutonium is not automatic grounds for assignment of safeguards and security level attractiveness level $\mathrm{E}$. The procedure includes the following steps.

1. Prepare a sample as prescribed in paragraph 7.1.3 of EPA Method 1311 (Rev. 0, July 1992). ${ }^{2}$ To assure comparability of data, it is important to maintain the particle size rang within close tolerances so that surface area, which limits dissolution rate, does not vary. Therefore, fines will be removed and the procedure will be conducted on samples which pass through a $3 / 8$ " screen but are retained on a $1 / 4$ " screen $(+1 / 4 "-3 / 8 ")$.

2. Prepare a $9 \mathrm{M}$ Nitric Acid solution. Add $\mathrm{CaF}_{2}(0.25$ moles per liter of nitric acid solution) to the nitric acid solution (not all $\mathrm{CaF}_{2}$ will dissolve).

3. Proportion the ratio of solid sample to acid solution so that for every 20 grams of sample, there is $100 \mathrm{ml}$ of acid solution.

4. Heat the acid solution to boiling range, then decrease temperature to $-30^{\circ} \mathrm{C}$ below boiling point (to avoid boil-over during sample addition).

5. Add sample to the hot acid solution and heat at reflux for at least 20 minutes from the point of solid addition but not more than 30 minutes of heating.

6. Cool the mixture to a convenient handling temperature $\left(20-50^{\circ} \mathrm{C}\right)$.

\footnotetext{
${ }^{1}$ RFETS PPC 88-003.

${ }^{2}$ Test Methods for Evaluating Solid Waste, Physical/Chemical Methods, SW-846, 3rd Edition, U.S. Environmental Protection Agency
} 
7. Formation of a colloidal sludge that absorbs $50 \%$ or more of the acid, by visual estimation, is evidence of practical irrecoverability and completion of the remaining steps is not necessary. Formation of the colloid indicates a silicate saturated solution (which may also have high ionic strength in other complicating species as well) which would interfere with numerous subsequent Plutonium recovery steps, including, filtration, Plutonium valence adjustments, $\mathrm{pH}$ adjustments, and ion exchange. In addition, large amounts of waste would be generated in subsequent Plutonium recovery steps. All of these factors are evidence that the waste form is analogous to a cemented waste form which has been defined as practically irrecoverable due to the above-mentioned complicating factors.

8. Filter the solution through progressively finer glass Büchner funnels (coarse, medium, and fine) until any of the following conditions are met: 1) the resulting solution does not exhibit cloudiness, or 2) the resulting solution does not scatter light, or 3) the fine filter has been used.

9. Analyze the supernatant for plutonium content and perform a plutonium mass balance between solid and liquid. If $<90 \%$ of the liquid is recovered, the Plutonium should be assumed to be equally distributed throughout the liquid phase and recovered Plutonium should be scaled to account for $100 \%$ of the liquid. Example calculations follow:

Table A.1: RFETS Approach to Satisfying Safeguards and Security Level E Criteria

\begin{tabular}{ccc}
\hline \hline $\begin{array}{c}\text { Final Waste Form } \\
\text { (any form) }\end{array}$ & $\begin{array}{c}\text { Level E Ceiling } \\
(\text { max g Pu/kg in final waste form) }\end{array}$ & $\begin{array}{c}\text { Recoverability Criteria }^{3} \\
\text { for Final Waste Form } \\
(\mathrm{g} \mathrm{Pu} \text { recovered } / \mathrm{kg} \text { final waste form) }\end{array}$ \\
\hline Sand, Slag, \& Crucible & 50 & $1.7^{4}$ \\
Incinerator Ash & 50 & $15^{5}$ \\
Graphite Fines & 50 & $4^{6}$ \\
\hline
\end{tabular}

${ }^{3}$ Recoverability Criteria = (attractiveness level E ceiling for the unstabilized waste form) $\mathrm{x}$ (Recovery efficiency for the original waste matrix).

${ }^{4} \cdot 1.7 \mathrm{~g}$ Pu recoverable $=[2.0 \mathrm{~g} \mathrm{Pu} / \mathrm{Kg}$ waste allowed in original matrix] x [85\% recoverability from original matrix] as referenced in LA-3542, Plutonium Processing at the Los Alamos Scientific Laboratory, E.L. Christensen and W.J. Maraman, University of California, April 1969.

s $15 \mathrm{~g}$ Pu recoverable $=[20 \mathrm{~g} \mathrm{Pu} / \mathrm{Kg}$ waste allowed in original matrix] $\mathrm{x}$ [75\% recoverability from original matrix] as referenced in RFP-1723, "Evaluation of Methods to Recover Plutonium from Incinerator Ash, D.L. Ziegler, et al., 8/16/71.

" $4 \mathrm{~g}$ Pu recoverable $=[10 \mathrm{~g} \mathrm{Pu} / \mathrm{Kg}$ waste allowed in original matrix] x [40\% recoverability from original matrix] as referenced in LA-3542, Plutonium Processing at the Los Alamos Scientific Laboratory, E.L. Christensen and W.J. Maraman, University of California, April 1969. 
Example Calculations

\section{Graphite Fines}

Graphite Fines are agglomerated using borosilicate glass to achieve a Plutonium loading of $<5$ wt\%. The product is broken out, sized-reduced and sieved. $40.1 \mathrm{~g}$ of the product which passes through the $3 / 8^{\prime}$ "screen but is retained on the $1 / 4$ " screen is added to $200 \mathrm{ml}$ of hot nitric $\mathrm{acid} / \mathrm{CaF}_{2}$ solution and refluxed for 23 minutes, then cooled to $35^{\circ} \mathrm{C}$. By visual inspection the agglomerated product is slightly dissolved, but remains largely unchanged. The sample easily filters using the fine fritted glass Büchner funnel and yielding $195 \mathrm{ml}$ of solution. The solution is assayed for Plutonium and found to contain $0.153 \mathrm{~g}$ of Plutonium.

To find out if the product successfully passed the Plutonium Recoverability Test, the Plutonium value must be converted to a $1 \mathrm{Kg}$ final waste form basis:

$\frac{0.153 \mathrm{~g} P u}{40.1 \mathrm{~g} \text { FinalWasteForm }}=\frac{X g \text { Pu }}{1000 \mathrm{~g} \text { FinalWasteForm }}$
Solving for $X$, we obtain $X=3.8 \mathrm{~g} P u$

Because more than $90 \%$ of the liquid was recovered during the filtration step, no additional correction is necessary. Comparing $3.8 \mathrm{~g}$ Plutonium obtained experimentally to the allowed value of $4.0 \mathrm{~g}$ Plutonium from Table A.1, the sample passes the Plutonium Recoverability test and is considered practically irrecoverable.

\section{Incinerator Ash}

Incinerator ash is immobilized in phosphate glass to achieve a Plutonium loading of $<5 \mathrm{wt} \%$. The product is broken out, sized-reduced and sieved. The product which passes through the $3 / 8$ " screen but is retained on the $1 / 4$ " screen is collected. $\sim 20 \mathrm{~g}$ of the collected product is weighed precisely, giving $19.27 \mathrm{~g}$ of sample. The sample is added to $95 \mathrm{ml}$ of hot nitric acid/ $\mathrm{CaF}_{2}$ solution and refluxed for 25 minutes. Most of the sample appears to dissolve. Upon cooling, a gelatinous mass is formed and occupies $\sim 25 \%$ of the solution volume, by visual estimation. The solution is passed through a coarse glass frit Büchner funnel, yielding $76 \mathrm{ml}$ of cloudy liquid. The cloudy liquid is passed through a medium glass frit Büchner funnel and yields $75.5 \mathrm{ml}$ of clear, light green solution. The clear green solution is assayed and determined to contain $0.245 \mathrm{~g}$ Plutonium.

Because $90 \%$ of the solution passed through the filter, the solution volume is corrected to take into account the volume retained by the colloid: 


$\frac{0.245 \mathrm{~g} P u}{75 m l \text { solution }}=\frac{X g P u}{95 m l \text { starting solution }}$
Solving for $X$, we obtain $X=0.31 \mathrm{~g} P u$

To find out if the product successfully passed the Plutonium Recoverability Test, the Plutonium value must be converted to a $1 \mathrm{Kg}$ final waste form basis:

\begin{tabular}{|l}
$\frac{0.31 \mathrm{~g} \mathrm{Pu}}{19.27 g \text { FinalWasteForm }}=\frac{Y g \text { Pu }}{1000 g \text { FinalWasteForm }}$ \\
Solving for $Y$, we obtain $Y=16.09 \mathrm{~g} P u$
\end{tabular}

Comparing 16.09g Plutonium obtained experimentally to the allowed value of $15 \mathrm{~g}$ Plutonium from Table A.1, the sample fails the Plutonium Recoverability test and is not practically irrecoverable. 


\section{Appendix B Waste Form Fabrication Data}

Feasibility Studies

Table B.1 Waste Form Formulation Data

\begin{tabular}{ccccccc}
\hline \hline $\begin{array}{c}\text { Run } \\
\text { Number }\end{array}$ & $\begin{array}{c}\text { Frit } \\
\text { Particle } \\
\text { Size } \\
(\mu \mathrm{m})\end{array}$ & $\begin{array}{c}\text { Frit to } \\
\text { Residue } \\
\text { Ratio }\end{array}$ & $\begin{array}{c}\text { Mass of } \\
\text { Graphite }\end{array}$ & $\begin{array}{c}\text { Mass of } \\
\mathrm{CaF}_{2}\end{array}$ & $\begin{array}{c}\text { Mass of } \\
\mathrm{CeO}_{2}\end{array}$ & $\begin{array}{c}\text { Mass of } \\
\text { Frit }\end{array}$ \\
\hline 2 & 10 & 8 & 40.56 & 8.34 & 6.67 & 444.45 \\
3 & 9 & 8 & 40.50 & 8.31 & 6.89 & 444.35 \\
$10 \mathrm{a}$ & 10 & 6 & 52.41 & 10.82 & 8.57 & 428.73 \\
$11 \mathrm{a}$ & 9 & 6 & 52.25 & 10.70 & 8.58 & 428.30 \\
6 & 10 & 4 & 73.00 & 15.02 & 12.00 & 400.01 \\
7 & 9 & 4 & 73.32 & 15.38 & 12.08 & 400.45 \\
$10 \mathrm{~b}$ & 10 & 3 & 91.31 & 18.77 & 15.15 & 375.66 \\
$11 \mathrm{~b}$ & 9 & 3 & 91.20 & 18.96 & 15.11 & 375.23 \\
\hline
\end{tabular}

Table B.2 Waste Form Fabrication Data Prior to Heating

\begin{tabular}{ccccccc}
\hline \hline $\begin{array}{c}\text { Run } \\
\text { Number }\end{array}$ & $\begin{array}{c}\text { Fabrication } \\
\text { Temp }\end{array}$ & $\begin{array}{c}\text { Empty } \\
\text { Beaker } \\
\text { Mass } \\
(\mathrm{g})\end{array}$ & $\begin{array}{c}\text { Full } \\
\text { Beaker } \\
\text { Mass } \\
(\mathrm{g})\end{array}$ & $\begin{array}{c}\text { Mass of } \\
\text { Starting } \\
\text { Materials } \\
(\mathrm{g})\end{array}$ & $\begin{array}{c}\text { Depth to } \\
\text { Material } \\
\text { Surface } \\
(\mathrm{cm})\end{array}$ & $\begin{array}{c}\text { Density of } \\
\text { Starting } \\
\text { Materials } \\
\left.(\mathrm{g}) / \mathrm{cm}^{3}\right)\end{array}$ \\
\hline 2 & 700 & 293.25 & 793.15 & 499.90 & 7.5 & 0.78 \\
3 & 700 & 293.41 & 793.35 & 499.94 & 6.2 & 0.67 \\
$10 \mathrm{a}$ & 700 & 288.22 & 788.69 & 500.47 & 7.1 & 0.75 \\
$11 \mathrm{a}$ & 700 & 288.35 & 787.89 & 499.54 & 6.2 & 0.67 \\
6 & 700 & 286.00 & 785.90 & 499.90 & 7.5 & 0.78 \\
7 & 700 & 286.20 & 787.25 & 501.05 & 5.9 & 0.65 \\
$10 \mathrm{~b}$ & 700 & 292.98 & 793.61 & 500.63 & 7.6 & 0.80 \\
$11 \mathrm{~b}$ & 700 & 293.11 & 793.35 & 500.24 & 5.7 & 0.64 \\
\hline
\end{tabular}

(1) Diameter of Stainless Steel Beaker $15.1 \mathrm{~cm}$ Height of Stainless Steel Beaker $10.3 \mathrm{~cm}$ 
WSRC-TR-98-00380

Revision 0

Table B.3 Waste Form Fabrication Data After Heating

\begin{tabular}{ccccccc}
\hline \hline $\begin{array}{c}\text { Run } \\
\text { Number }\end{array}$ & $\begin{array}{c}\text { Heating } \\
\text { Time }\end{array}$ & $\begin{array}{c}\text { Beaker } \\
\text { Mass }\end{array}$ & $\begin{array}{c}\text { Waste } \\
\text { Form } \\
\text { Mass } \\
(\mathrm{gr})\end{array}$ & $\begin{array}{c}\text { Mass Loss } \\
\text { Upon } \\
\text { Heating } \\
(\mathrm{g})\end{array}$ & $\begin{array}{c}\text { Depth to } \\
\text { Material } \\
\text { Surface } \\
(\mathrm{cm})\end{array}$ & $\begin{array}{c}\text { Density of } \\
\text { Waste } \\
\text { Form }^{(1)}\end{array}$ \\
\hline 2 & 2 & 790.80 & 497.55 & 2.35 & 11.6 & 1.70 \\
3 & 2 & 790.36 & 496.95 & 2.99 & 11.3 & 1.56 \\
$10 \mathrm{a}$ & 2 & 785.35 & 497.13 & 3.34 & 11.7 & 1.78 \\
$11 \mathrm{a}$ & 2 & 783.44 & 495.09 & 4.45 & 11.0 & 1.43 \\
6 & 2 & 779.66 & 493.66 & 6.24 & 10.3 & 1.24 \\
7 & 2 & 780.22 & 494.02 & 7.03 & 9.8 & 1.13 \\
$10 \mathrm{~b}$ & 2 & 786.33 & 493.35 & 7.28 & 10.0 & 1.16 \\
$11 \mathrm{~b}$ & 2 & 785.11 & 492.00 & 8.24 & 9.0 & 0.98 \\
\hline (1) Diameter of Stainless Steel Beaker 15.1 $\mathrm{cm}$ & & & &
\end{tabular}

Height of Stainless Steel Beaker $10.3 \mathrm{~cm}$

Table B.4 Recoverability Test Results

\begin{tabular}{ccccc}
\hline \hline $\begin{array}{c}\text { Run } \\
\text { Number }\end{array}$ & $\begin{array}{c}\text { Sample } \\
\text { Mass } \\
(\mathrm{g})\end{array}$ & $\begin{array}{c}\text { Dissolution } \\
\text { Time } \\
(\mathrm{min})\end{array}$ & $\begin{array}{c}\text { Volume of } \\
\text { Filtrate } \\
(\mathrm{ml})\end{array}$ & $\begin{array}{c}\text { Cerium } \\
\text { Concentration } \\
(\mathrm{mg} / \mathrm{l})\end{array}$ \\
\hline 2 & 19.99 & 20 & 95 & 85.46 \\
3 & 20.04 & 20 & 85 & 188.1 \\
$10 \mathrm{a}$ & 20.33 & 20 & 90 & 383.3 \\
$11 \mathrm{a}$ & 20.15 & 20 & 80 & 396.4 \\
6 & 20.29 & 20 & 93 & 704.3 \\
7 & 20.12 & 20 & 79 & 691.6 \\
$10 \mathrm{~b}$ & 20.24 & 20 & 89 & 1047 \\
$11 \mathrm{~b}$ & 20.15 & 20 & 80 & 1055 \\
\hline
\end{tabular}


Calcium Fluoride Variability Study

Table B.5 Waste Form Formulation Data

\begin{tabular}{ccccccc}
\hline \hline $\begin{array}{c}\text { Run } \\
\text { Number }\end{array}$ & $\begin{array}{c}\text { Frit } \\
\text { Particle } \\
\text { Size } \\
(\mu \mathrm{m})\end{array}$ & $\begin{array}{c}\text { Frit to } \\
\text { Residue } \\
\text { Ratio }\end{array}$ & $\begin{array}{c}\text { Mass of } \\
\text { Graphite } \\
(\mathrm{g})\end{array}$ & $\begin{array}{c}\text { Mass of } \\
\mathrm{CaF}_{2} \\
(\mathrm{~g})\end{array}$ & $\begin{array}{c}\text { Mass of } \\
\mathrm{CeO}_{2}\end{array}$ & $\begin{array}{c}\text { Mass of } \\
\text { Frit }\end{array}$ \\
\hline $\mathrm{A}$ & 10 & 4 & 73.09 & 15.01 & 12.00 & 400.06 \\
$\mathrm{~B}$ & 10 & 4 & 88.13 & 0.00 & 12.36 & 400.18 \\
$\mathrm{C}$ & 10 & 4 & 63.06 & 25.10 & 12.19 & 400.08 \\
$\mathrm{D}$ & 10 & 4 & 38.07 & 50.13 & 12.18 & 400.06 \\
$\mathrm{E}$ & 10 & 4 & 38.00 & 50.09 & 12.05 & 400.02 \\
$\mathrm{~F}$ & 10 & 6 & 27.15 & 35.72 & 8.59 & 428.59 \\
$\mathrm{G}$ & 10 & 6 & 27.28 & 35.71 & 8.83 & 428.59 \\
$\mathrm{H}$ & 9 & 8 & 21.11 & 27.81 & 6.70 & 444.51 \\
\hline
\end{tabular}

Table B.6 Waste Form Fabrication Data Prior to Heating

\begin{tabular}{ccccccc}
\hline \hline $\begin{array}{c}\text { Run } \\
\text { Number }\end{array}$ & $\begin{array}{c}\text { Fabrication } \\
\text { Temp }\end{array}$ & $\begin{array}{c}\text { Empty } \\
\text { Beaker } \\
\text { Mass } \\
(\mathrm{g})\end{array}$ & $\begin{array}{c}\text { Full } \\
\text { Beaker } \\
\text { Mass } \\
(\mathrm{g})\end{array}$ & $\begin{array}{c}\text { Mass of } \\
\text { Starting } \\
\text { Materials } \\
(\mathrm{g})\end{array}$ & $\begin{array}{c}\text { Depth to } \\
\text { Material } \\
\text { Surface } \\
(\mathrm{cm})\end{array}$ & $\begin{array}{c}\text { Density of } \\
\text { Starting } \\
\text { Materials } \\
\left(\mathrm{g} / \mathrm{cm}^{3}\right)\end{array}$ \\
\hline $\mathrm{A}$ & $700 \mathrm{C})$ & 292.31 & 792.38 & 500.07 & 5.1 & 0.60 \\
$\mathrm{~A}^{(2)}$ & 700 & 292.31 & 792.28 & 499.97 & 8.7 & 0.94 \\
$\mathrm{~B}$ & 700 & 288.58 & 789.11 & 500.53 & 5.6 & 0.63 \\
$\mathrm{C}$ & 700 & 286.38 & 786.69 & 500.31 & 5.1 & 0.60 \\
$\mathrm{D}$ & 700 & 293.40 & 793.77 & 500.37 & 4.3 & 0.55 \\
$\mathrm{E}$ & 700 & 292.28 & 792.36 & 500.08 & 5.4 & 0.62 \\
$\mathrm{E}^{(2)}$ & 700 & 292.28 & 792.38 & 500.10 & 8.9 & 0.97 \\
$\mathrm{~F}$ & 700 & 288.94 & 788.93 & 499.99 & 3.3 & 0.51 \\
$\mathrm{~F}^{(2)}$ & 700 & 288.94 & 788.98 & 500.04 & 8.6 & 0.92 \\
$\mathrm{G}$ & 700 & 289.94 & 790.26 & 500.32 & 5.6 & 0.63 \\
$\mathrm{H}$ & 700 & 306.88 & 806.90 & 500.02 & 6.2 & 0.67 \\
\hline
\end{tabular}

(1) Diameter of Stainless Steel Beaker $15.1 \mathrm{~cm}$ Height of Stainless Steel Beaker $10.3 \mathrm{~cm}$

(2) Following Compaction 
WSRC-TR-98-00380

Revision 0

Table B.7 Waste Form Fabrication Data After Heating

\begin{tabular}{ccccccc}
\hline \hline $\begin{array}{c}\text { Run } \\
\text { Number }\end{array}$ & $\begin{array}{c}\text { Heating } \\
\text { Time }\end{array}$ & $\begin{array}{c}\text { Beaker } \\
\text { Mass }\end{array}$ & $\begin{array}{c}\text { Waste } \\
\text { Form } \\
\text { Mass } \\
(\mathrm{g})\end{array}$ & $\begin{array}{c}\text { Mass Loss } \\
\text { Upon } \\
\text { Heating } \\
(\mathrm{g})\end{array}$ & $\begin{array}{c}\text { Depth to } \\
\text { Material } \\
\text { Surface } \\
(\mathrm{cm})\end{array}$ & $\begin{array}{c}\text { Density of } \\
\text { Waste } \\
\text { Form }^{(1)}\end{array}$ \\
\hline A & 2 & 789.42 & 497.11 & 2.86 & 10.3 & 1.25 \\
B & 2 & 781.55 & 492.97 & 7.56 & 9.2 & 1.00 \\
C & 2 & 780.68 & 494.30 & 6.01 & 10.0 & 1.16 \\
D & 2 & 789.56 & 496.16 & 4.21 & 10.8 & 1.38 \\
E & 2 & 789.38 & 497.10 & $3.00^{(2)}$ & 9.7 & 1.10 \\
F & 2 & 785.98 & 497.04 & $3.00^{(2)}$ & 9.5 & 1.07 \\
G & 2 & 787.72 & 497.78 & 2.54 & 10.3 & 1.25 \\
H & 2 & 804.42 & 497.54 & 2.48 & 10.8 & 1.39 \\
\hline
\end{tabular}

(1) Diameter of Stainless Steel Beaker $15.1 \mathrm{~cm}$

Height of Stainless Steel Beaker $10.3 \mathrm{~cm}$

(2) The beaker mass following heating was not measured; a 3.00 mass loss during heating was assumed.

Table B.8 Recoverability Test Results

\begin{tabular}{ccccc}
\hline \hline $\begin{array}{c}\text { Run } \\
\text { Number }\end{array}$ & $\begin{array}{c}\text { Sample } \\
\text { Mass } \\
(\mathrm{g})\end{array}$ & $\begin{array}{c}\text { Dissolution } \\
\text { Time } \\
(\mathrm{min})\end{array}$ & $\begin{array}{c}\text { Volume of } \\
\text { Filtrate } \\
(\mathrm{ml})\end{array}$ & $\begin{array}{c}\text { Cerium } \\
\text { Concentration } \\
(\mathrm{mg} / l)\end{array}$ \\
\hline A & 20.07 & 20 & 87 & 816.8 \\
B & 20.03 & 20 & 82 & 784.7 \\
C & 20.12 & 20 & 96 & 674.0 \\
D & 20.18 & 15 & 94 & 372.6 \\
E & 20.12 & 20 & 92 & 361.2 \\
F & 20.18 & 20 & 93 & 136.5 \\
G & 20.15 & 20 & 90 & 125.9 \\
H & 20.09 & 20 & 96 & 68.46 \\
\hline
\end{tabular}


Heating Cycle Studies

Table B.9 Waste Form Formulation Data

\begin{tabular}{|c|c|c|c|c|c|c|}
\hline $\begin{array}{l}\text { Run } \\
\text { Number }\end{array}$ & $\begin{array}{c}\text { Frit } \\
\text { Particle } \\
\text { Size } \\
(\mu \mathrm{m}) \\
\end{array}$ & $\begin{array}{l}\text { Frit to } \\
\text { Residue } \\
\text { Ratio }\end{array}$ & $\begin{array}{l}\text { Mass of } \\
\text { Graphite } \\
\text { (g) }\end{array}$ & $\begin{array}{c}\text { Mass of } \\
\mathrm{CaF}_{2} \\
(\mathrm{~g}) \\
\end{array}$ & $\begin{array}{c}\text { Mass of } \\
\mathrm{CeO}_{2} \\
(\mathrm{~g}) \\
\end{array}$ & $\begin{array}{c}\text { Mass of } \\
\text { Frit } \\
\text { (g) }\end{array}$ \\
\hline la & 10 & 4 & 22.16 & 0.00 & 3.10 & 100.30 \\
\hline $1 b$ & 10 & 4 & 9.54 & 12.76 & 3.14 & 101.31 \\
\hline $2 a$ & 10 & 4 & 22.01 & 0.00 & 3.57 & 100.05 \\
\hline $2 b$ & 10 & 4 & 9.55 & 12.51 & 3.23 & 100.30 \\
\hline $3 a$ & 10 & 4 & 22.56 & 0.00 & 3.21 & 100.86 \\
\hline $3 b$ & 10 & 4 & 9.70 & 12.61 & 3.26 & 100.39 \\
\hline $4 a$ & 10 & 4 & 22.23 & 0.00 & 3.20 & 100.33 \\
\hline $4 \mathrm{~b}$ & 10 & 4 & 9.54 & 12.56 & 3.09 & 100.07 \\
\hline $5 a$ & 10 & 4 & 22.25 & 0.00 & 3.10 & 100.36 \\
\hline $5 b$ & 10 & 4 & 9.51 & 12.70 & 3.33 & 100.25 \\
\hline $6 a$ & 10 & 4 & 22.40 & 0.00 & 3.01 & 100.26 \\
\hline $6 b$ & 10 & 4 & 9.50 & 12.58 & 3.19 & 100.02 \\
\hline $7 a$ & 10 & 4 & 22.39 & 0.00 & 3.01 & 100.43 \\
\hline $7 b$ & 10 & 4 & 9.55 & 12.60 & 3.09 & 100.25 \\
\hline $8 a$ & 10 & 4 & 22.36 & 0.00 & 3.01 & 100.39 \\
\hline $8 b$ & 10 & 4 & 9.56 & 12.49 & 3.30 & 100.42 \\
\hline $9 \mathrm{a}$ & 10 & 4 & 22.01 & 0.00 & 3.29 & 100.03 \\
\hline $9 b$ & 10 & 4 & 9.59 & 12.59 & 3.14 & 100.01 \\
\hline $10 \mathrm{a}$ & 10 & 4 & 22.00 & 0.00 & 3.12 & 100.11 \\
\hline $10 \mathrm{~b}$ & 10 & 4 & 9.89 & 12.61 & 3.00 & 100.10 \\
\hline $11 \mathrm{a}$ & 10 & 4 & 22.00 & 0.00 & 3.03 & 100.47 \\
\hline $11 \mathrm{~b}$ & 10 & 4 & 9.51 & 12.50 & 3.04 & 100.31 \\
\hline $12 \mathrm{a}$ & 10 & 4 & 22.13 & 0.00 & 4.09 & 100.18 \\
\hline $12 b$ & 10 & 4 & 9.52 & 12.49 & 3.06 & 100.57 \\
\hline $13 a$ & 10 & 4 & 22.67 & 0.00 & 3.17 & 100.60 \\
\hline $13 b$ & 10 & 4 & 9.50 & 12.53 & 3.57 & 100.42 \\
\hline $14 a$ & 10 & 4 & 22.06 & 0.00 & 3.16 & 100.28 \\
\hline $14 \mathrm{~b}$ & 10 & 4 & 9.73 & 12.50 & 3.00 & 100.13 \\
\hline $15 \mathrm{a}$ & 10 & 4 & 22.08 & 0.00 & 3.00 & 100.35 \\
\hline $15 b$ & 10 & 4 & 9.51 & 12.50 & 3.02 & 100.07 \\
\hline $16 \mathrm{a}$ & 10 & 4 & 22.09 & 0.00 & 3.21 & 100.52 \\
\hline $16 b$ & 10 & 4 & 9.50 & 12.50 & 3.01 & 100.34 \\
\hline
\end{tabular}


WSRC-TR-98-00380

Revision 0

Table B.9 Continued

\begin{tabular}{|c|c|c|c|c|c|c|}
\hline $\begin{array}{c}\text { Run } \\
\text { Number }\end{array}$ & $\begin{array}{c}\text { Frit } \\
\text { Particle } \\
\text { Size } \\
(\mu \mathrm{m}) \\
\end{array}$ & $\begin{array}{c}\text { Frit to } \\
\text { Residue } \\
\text { Ratio }\end{array}$ & $\begin{array}{c}\text { Mass of } \\
\text { Graphite } \\
\text { (g) }\end{array}$ & $\begin{array}{c}\text { Mass of } \\
\mathrm{CaF}_{2} \\
(\mathrm{~g}) \\
\end{array}$ & $\begin{array}{c}\text { Mass of } \\
\mathrm{CeO}_{2} \\
(\mathrm{~g}) \\
\end{array}$ & $\begin{array}{c}\text { Mass of } \\
\text { Frit } \\
\text { (g) }\end{array}$ \\
\hline $17 \mathrm{a}$ & 10 & 4 & 22.39 & 0.00 & 3.25 & 100.20 \\
\hline $17 b$ & 10 & 4 & 9.52 & 12.58 & 3.00 & 100.34 \\
\hline $18 \mathrm{a}$ & 10 & 4 & 22.15 & 0.00 & 3.07 & 100.15 \\
\hline $18 b$ & 10 & 4 & 9.50 & 12.50 & 3.06 & 100.12 \\
\hline $19 a$ & 10 & 4 & 22.19 & 0.00 & 3.02 & 100.06 \\
\hline $19 b$ & 10 & 4 & 9.59 & 12.50 & 3.07 & 100.40 \\
\hline $20 a$ & 10 & 4 & 22.01 & 0.00 & 3.15 & 100.28 \\
\hline $20 \mathrm{~b}$ & 10 & 4 & 9.52 & 12.62 & 3.00 & 100.41 \\
\hline $21 a$ & 10 & 4 & 22.00 & 0.00 & 3.06 & 100.04 \\
\hline $21 b$ & 10 & 4 & 9.62 & 12.92 & 3.14 & 100.08 \\
\hline $22 \mathrm{a}$ & 10 & 4 & 22.16 & 0.00 & 3.07 & 100.01 \\
\hline $22 b$ & 10 & 4 & 9.51 & 12.52 & 3.03 & 100.01 \\
\hline $23 a$ & 10 & 4 & 22.00 & 0.00 & 3.09 & 100.28 \\
\hline $23 b$ & 10 & 4 & 9.63 & 12.50 & 3.18 & 100.18 \\
\hline $24 a$ & 10 & 4 & 22.02 & 0.00 & 3.09 & 100.22 \\
\hline $24 b$ & 10 & 4 & 9.50 & 12.56 & 3.22 & 100.16 \\
\hline $25 a$ & 10 & 4 & 22.19 & 0.00 & 3.06 & 100.41 \\
\hline $25 b$ & 10 & 4 & 9.66 & 12.75 & 3.11 & 100.01 \\
\hline $26 a$ & 10 & 4 & 22.01 & 0.00 & 3.01 & 100.12 \\
\hline $26 b$ & 10 & 4 & 9.74 & 12.67 & 3.00 & 100.13 \\
\hline $27 a$ & 10 & 4 & 22.29 & 0.00 & 3.06 & 100.70 \\
\hline $27 b$ & 10 & 4 & 9.59 & 12.59 & 3.22 & 100.10 \\
\hline $28 \mathrm{a}$ & 10 & 4 & 22.33 & 0.00 & 3.06 & 100.70 \\
\hline $28 \mathrm{~b}$ & 10 & 4 & 9.50 & 12.68 & 3.00 & 100.90 \\
\hline
\end{tabular}


Table B.10 Waste Form Fabrication Data Prior to Heating

\begin{tabular}{|c|c|c|c|c|c|c|}
\hline $\begin{array}{c}\text { Run } \\
\text { Number }\end{array}$ & $\begin{array}{c}\text { Fabrication } \\
\text { Temp } \\
\left({ }^{\circ} \mathrm{C}\right)\end{array}$ & $\begin{array}{c}\text { Empty } \\
\text { Beaker } \\
\text { Mass } \\
(\mathrm{g})\end{array}$ & $\begin{array}{c}\text { Full } \\
\text { Beaker } \\
\text { Mass } \\
(\mathrm{g})\end{array}$ & $\begin{array}{c}\text { Mass of } \\
\text { Starting } \\
\text { Materials } \\
\text { (g) }\end{array}$ & $\begin{array}{l}\text { Depth to } \\
\text { Material } \\
\text { Surface } \\
\text { (cm) }\end{array}$ & $\begin{array}{c}\text { Density of } \\
\text { Starting } \\
\text { Materials } \\
\left(\mathrm{g} / \mathrm{cm}^{3}\right)\end{array}$ \\
\hline $1 \mathrm{a}$ & 600 & 266.26 & 391.42 & 125.16 & 10.8 & 0.64 \\
\hline $1 \mathrm{~b}$ & 600 & 266.32 & 393.02 & 126.70 & 10.6 & 0.60 \\
\hline $2 a$ & 600 & 266.76 & 392.34 & 125.58 & 10.8 & 0.64 \\
\hline $2 b$ & 600 & 263.73 & 389.27 & 125.54 & 10.6 & 0.59 \\
\hline $3 a$ & 850 & 266.80 & 393.38 & 126.58 & 10.8 & 0.65 \\
\hline $3 b$ & 850 & 263.77 & 389.75 & 125.98 & 10.7 & 0.62 \\
\hline $4 a$ & 850 & 266.29 & 391.98 & 125.69 & 10.9 & 0.67 \\
\hline $4 b$ & 850 & 266.34 & 391.56 & 125.22 & 10.6 & 0.59 \\
\hline $5 a$ & 600 & 266.83 & 392.58 & 125.75 & 10.7 & 0.62 \\
\hline $5 b$ & 600 & 264.18 & 389.99 & 125.81 & 10.7 & 0.62 \\
\hline $6 a$ & 600 & 267.49 & 393.11 & 125.62 & 10.9 & 0.67 \\
\hline $6 b$ & 600 & 266.03 & 391.30 & 125.27 & 10.7 & 0.61 \\
\hline $7 \mathrm{a}$ & 700 & 266.97 & 392.58 & 125.61 & 10.9 & 0.67 \\
\hline $7 b$ & 700 & 264.27 & 389.75 & 125.48 & 10.8 & 0.64 \\
\hline $8 \mathrm{a}$ & 700 & 267.45 & 393.23 & 125.78 & 10.7 & 0.62 \\
\hline $8 b$ & 700 & 266.04 & 391.85 & 125.81 & 10.6 & 0.59 \\
\hline $9 a$ & 650 & 267.01 & 392.31 & 125.30 & 10.8 & 0.64 \\
\hline $9 b$ & 650 & 267.75 & 393.06 & 125.31 & 10.7 & 0.61 \\
\hline $10 a$ & 650 & 266.80 & 392.04 & 125.24 & 10.7 & 0.61 \\
\hline $10 b$ & 650 & 262.11 & 387.72 & 125.61 & 10.6 & 0.59 \\
\hline $11 \mathrm{a}$ & 600 & 266.72 & 392.18 & 125.46 & 10.9 & 0.67 \\
\hline $11 b$ & 600 & 262.32 & 387.66 & 125.34 & 11.1 & 0.74 \\
\hline $12 \mathrm{a}$ & 600 & 267.12 & 393.48 & 126.36 & 10.8 & 0.65 \\
\hline $12 b$ & 600 & 267.81 & 393.43 & 125.62 & 10.9 & 0.67 \\
\hline $13 a$ & 850 & 266.77 & 393.17 & 126.40 & 10.5 & 0.57 \\
\hline $13 b$ & 850 & 262.32 & 388.30 & 125.98 & 10.7 & 0.62 \\
\hline $14 a$ & 850 & 267.19 & 392.64 & 125.45 & 10.7 & 0.62 \\
\hline $14 b$ & 850 & 268.31 & 393.64 & 125.33 & 10.9 & 0.67 \\
\hline $15 a$ & 650 & 268.79 & 397.02 & 128.23 & 10.6 & 0.60 \\
\hline $15 b$ & 650 & 267.99 & 393.16 & 125.17 & 10.6 & 0.59 \\
\hline $16 a$ & 650 & 269.39 & 395.03 & 125.64 & 10.8 & 0.64 \\
\hline $16 b$ & 650 & 265.71 & 391.38 & 125.67 & 10.8 & 0.64 \\
\hline
\end{tabular}


Table B.10 Continued

\begin{tabular}{ccccccc}
\hline \hline $\begin{array}{c}\text { Run } \\
\text { Number }\end{array}$ & $\begin{array}{c}\text { Fabrication } \\
\text { Temp }\end{array}$ & $\begin{array}{c}\text { Empty } \\
\text { Beaker } \\
\text { Mass } \\
(\mathrm{g})\end{array}$ & $\begin{array}{c}\text { Full } \\
\text { Beaker } \\
\text { Mass } \\
(\mathrm{g})\end{array}$ & $\begin{array}{c}\text { Mass of } \\
\text { Starting } \\
\text { Materials } \\
(\mathrm{g})\end{array}$ & $\begin{array}{c}\text { Depth to } \\
\text { Material } \\
\text { Surface } \\
(\mathrm{cm})\end{array}$ & $\begin{array}{c}\text { Density of } \\
\text { Starting } \\
\text { Materials } \\
\left(\mathrm{g} / \mathrm{cm}^{3}\right)\end{array}$ \\
\hline $17 \mathrm{a}$ & 675 & 268.79 & 394.61 & 125.82 & 10.8 & 0.64 \\
$17 \mathrm{~b}$ & 675 & 268.15 & 393.64 & 125.49 & 10.7 & 0.62 \\
$18 \mathrm{a}$ & 675 & 269.43 & 394.75 & 125.32 & 10.8 & 0.64 \\
$18 \mathrm{~b}$ & 675 & 266.87 & 391.98 & 125.11 & 10.9 & 0.67 \\
$19 \mathrm{a}$ & 850 & 268.97 & 394.20 & 125.23 & 10.9 & 0.67 \\
$19 \mathrm{~b}$ & 850 & 268.14 & 393.67 & 125.53 & 10.8 & 0.64 \\
$20 \mathrm{a}$ & 850 & 269.45 & 394.83 & 125.38 & 10.7 & 0.61 \\
$20 \mathrm{~b}$ & 850 & 267.06 & 392.55 & 125.49 & 10.8 & 0.64 \\
$21 \mathrm{a}$ & 800 & 269.67 & 394.72 & 125.05 & 10.6 & 0.59 \\
$21 \mathrm{~b}$ & 800 & 267.86 & 393.62 & 125.76 & 10.5 & 0.57 \\
$22 \mathrm{a}$ & 800 & 270.61 & 395.81 & 125.20 & 10.5 & 0.57 \\
$22 \mathrm{~b}$ & 800 & 267.59 & 392.68 & 125.09 & 10.6 & 0.59 \\
$23 \mathrm{a}$ & 750 & 270.04 & 395.56 & 125.52 & 10.7 & 0.62 \\
$23 \mathrm{~b}$ & 750 & 268.05 & 396.56 & 128.51 & 10.7 & 0.63 \\
$24 \mathrm{a}$ & 750 & 270.99 & 396.31 & 125.32 & 10.7 & 0.61 \\
$24 \mathrm{~b}$ & 750 & 268.01 & 393.43 & 125.42 & 10.6 & 0.59 \\
$25 \mathrm{a}$ & 750 & 277.08 & 396.72 & 119.64 & 11.4 & 0.83 \\
$25 \mathrm{~b}$ & 750 & 269.46 & 395.00 & 125.54 & 11.3 & 0.82 \\
$26 \mathrm{a}$ & 750 & 270.54 & 395.66 & 125.12 & 11.2 & 0.78 \\
$26 \mathrm{~b}$ & 750 & 268.39 & 393.43 & 125.04 & 11.0 & 0.70 \\
$27 \mathrm{a}$ & 800 & 271.24 & 395.96 & 124.72 & 10.7 & 0.61 \\
$27 \mathrm{~b}$ & 800 & 268.20 & 393.67 & 125.47 & 10.7 & 0.62 \\
$28 \mathrm{a}$ & 800 & 269.01 & 394.44 & 125.43 & 10.4 & 0.55 \\
$28 \mathrm{~b}$ & 800 & 270.98 & 396.23 & 125.25 & 11.0 & 0.70 \\
\hline
\end{tabular}

(1) Diameter of Stainless Steel Beaker $13.1 \mathrm{~cm}$ Height of Stainless Steel Beaker $10.4 \mathrm{~cm}$ 
WSRC-TR-98-00380

Revision 0

Table B.11 Waste Form Fabrication Data After Heating

\begin{tabular}{|c|c|c|c|c|c|c|}
\hline $\begin{array}{c}\text { Run } \\
\text { Number }\end{array}$ & $\begin{array}{l}\text { Heating } \\
\text { Time } \\
(\mathrm{hr})\end{array}$ & $\begin{array}{c}\text { Beaker } \\
\text { Mass } \\
\text { (g) }\end{array}$ & $\begin{array}{l}\text { Waste } \\
\text { Form } \\
\text { Mass } \\
(\mathrm{g})\end{array}$ & $\begin{array}{c}\text { Mass Loss } \\
\text { Upon } \\
\text { Heating } \\
(\mathrm{g})\end{array}$ & $\begin{array}{l}\text { Depth to } \\
\text { Material } \\
\text { Surface } \\
(\mathrm{cm})\end{array}$ & $\begin{array}{c}\text { Density of } \\
\text { Waste } \\
\text { Form }^{(1)}\end{array}$ \\
\hline $1 \mathrm{a}$ & 0.0 & 391.28 & 125.02 & 0.14 & 10.8 & 0.64 \\
\hline $1 b$ & 0.0 & 393.00 & 126.68 & 0.02 & 10.6 & 0.60 \\
\hline $2 a$ & 0.5 & 390.21 & 123.45 & 2.13 & 11.3 & 0.81 \\
\hline $2 b$ & 0.5 & 388.07 & 124.34 & 1.20 & 11.3 & 0.81 \\
\hline $3 a$ & 0.0 & 392.12 & 125.32 & 1.26 & 11.7 & 1.05 \\
\hline $3 b$ & 0.0 & 388.93 & 125.16 & 0.82 & 11.8 & 1.13 \\
\hline $4 a$ & 0.5 & 389.57 & 123.28 & 2.41 & 11.8 & 1.12 \\
\hline $4 b$ & 0.5 & 389.78 & 123.44 & 1.78 & 12.2 & 1.61 \\
\hline $5 \mathrm{a}$ & 1.0 & 390.61 & 123.78 & 1.97 & 11.3 & 1.65 \\
\hline $5 b$ & 1.0 & 388.43 & 124.25 & 1.56 & 11.2 & 1.57 \\
\hline $6 a$ & 1.5 & 390.25 & 122.76 & 2.86 & 11.5 & 1.69 \\
\hline $6 b$ & 1.5 & 390.00 & 123.97 & 1.30 & 11.2 & 1.57 \\
\hline $7 \mathrm{a}$ & 0.5 & 390.79 & 123.82 & 1.79 & 11.3 & 1.51 \\
\hline $7 b$ & 0.5 & 388.53 & 124.26 & 1.22 & 11.8 & 2.20 \\
\hline $8 a$ & 1.0 & 390.81 & 123.36 & 2.42 & 11.3 & 1.64 \\
\hline $8 b$ & 1.0 & 390.23 & 124.19 & 1.62 & 11.7 & 2.22 \\
\hline $9 a$ & 0.5 & 390.63 & 123.62 & 1.68 & 11.3 & 1.58 \\
\hline $9 b$ & 0.5 & 391.87 & 124.12 & 1.19 & 11.7 & 2.13 \\
\hline $10 \mathrm{a}$ & 1.0 & 389.18 & 122.38 & 2.86 & 11.2 & 1.55 \\
\hline $10 b$ & 1.0 & 386.52 & 124.41 & 1.20 & 11.8 & 2.39 \\
\hline $11 a$ & 2.0 & 388.78 & 122.06 & 3.40 & 11.4 & 1.58 \\
\hline $11 \mathrm{~b}$ & 2.0 & 386.32 & 124.00 & 1.34 & 11.4 & 1.46 \\
\hline $12 \mathrm{a}$ & 2.5 & 388.61 & 121.49 & 4.87 & 11.5 & 1.75 \\
\hline $12 b$ & 2.5 & 391.35 & 123.54 & 2.08 & 11.5 & 1.70 \\
\hline $13 a$ & 1.0 & 390.21 & 123.44 & 2.96 & 11.2 & 1.69 \\
\hline $13 b$ & 1.0 & 385.99 & 123.67 & 2.31 & 12.0 & 2.70 \\
\hline $14 \mathrm{a}$ & 1.5 & 388.45 & 121.26 & 4.19 & 11.6 & 1.94 \\
\hline $14 b$ & 1.5 & 390.87 & 122.56 & 2.77 & 12.6 & 5.39 \\
\hline $15 \mathrm{a}$ & 1.5 & 393.95 & 125.16 & 3.07 & 11.2 & 1.65 \\
\hline $15 b$ & 1.5 & 391.69 & 123.70 & 1.47 & 11.4 & 1.82 \\
\hline $16 \mathrm{a}$ & 2.0 & 391.17 & 121.78 & 3.86 & 11.4 & 1.65 \\
\hline $16 b$ & 2.0 & 389.54 & 123.83 & 1.84 & 11.4 & 1.68 \\
\hline
\end{tabular}


WSRC-TR-98-00380

Revision 0

Table B.11 Continued

\begin{tabular}{ccccccc}
\hline \hline $\begin{array}{c}\text { Run } \\
\text { Number }\end{array}$ & $\begin{array}{c}\text { Heating } \\
\text { Time }\end{array}$ & $\begin{array}{c}\text { Beaker } \\
\text { Mass }\end{array}$ & $\begin{array}{c}\text { Waste } \\
\text { Form } \\
\text { Mass } \\
(\mathrm{g})\end{array}$ & $\begin{array}{c}\text { Mass Loss } \\
\text { Upon } \\
\text { Heating } \\
(\mathrm{g})\end{array}$ & $\begin{array}{c}\text { Depth to } \\
\text { Material } \\
\text { Surface } \\
(\mathrm{cm})\end{array}$ & $\begin{array}{c}\text { Density of } \\
\text { Waste } \\
\text { Form }\end{array}$ \\
\hline $17 \mathrm{a}$ & 0.5 & 392.61 & 123.82 & 2.00 & 11.4 & 1.68 \\
$17 \mathrm{~b}$ & 0.5 & 392.55 & 124.40 & 1.09 & 11.5 & 1.87 \\
$18 \mathrm{a}$ & 1.0 & 392.14 & 122.71 & 2.61 & 11.4 & 1.66 \\
$18 \mathrm{~b}$ & 1.0 & 390.61 & 123.74 & 1.37 & 11.6 & 1.81 \\
$19 \mathrm{a}$ & 1.0 & 391.26 & 122.29 & 2.94 & 11.6 & 1.79 \\
$19 \mathrm{~b}$ & 1.0 & 391.49 & 123.35 & 2.18 & 11.4 & 1.67 \\
$20 \mathrm{a}$ & 1.5 & 391.05 & 121.60 & 3.78 & 11.5 & 1.82 \\
$20 \mathrm{~b}$ & 1.5 & 390.05 & 122.99 & 2.50 & 11.4 & 1.66 \\
$21 \mathrm{a}$ & 0.5 & 392.50 & 122.83 & 2.22 & 11.4 & 1.81 \\
$21 \mathrm{~b}$ & 0.5 & 392.08 & 124.22 & 1.54 & 11.7 & 2.31 \\
$22 \mathrm{a}$ & 1.0 & 393.03 & 122.42 & 2.78 & 11.2 & 1.68 \\
$22 \mathrm{~b}$ & 1.0 & 390.79 & 123.20 & 1.89 & 12.1 & 3.08 \\
$23 \mathrm{a}$ & 0.5 & 393.29 & 123.25 & 2.27 & 11.4 & 1.74 \\
$23 \mathrm{~b}$ & 0.5 & 392.34 & 124.29 & 4.22 & 11.8 & 2.29 \\
$24 \mathrm{a}$ & 1.0 & 393.41 & 122.42 & 2.90 & 11.6 & 1.96 \\
$24 \mathrm{~b}$ & 1.0 & 391.96 & 123.95 & 1.47 & 11.9 & 2.58 \\
$25 \mathrm{a}$ & 1.5 & 393.42 & 116.34 & 3.30 & 11.8 & 1.52 \\
$25 \mathrm{~b}$ & 1.5 & 392.88 & 123.42 & 2.12 & 12.1 & 2.22 \\
$26 \mathrm{a}$ & 2.0 & 391.24 & 120.70 & 4.42 & 11.6 & 1.53 \\
$26 \mathrm{~b}$ & 2.0 & 392.21 & 123.82 & 1.22 & 12.0 & 2.36 \\
$27 \mathrm{a}$ & 1.5 & 392.52 & 121.28 & 3.44 & 11.4 & 1.71 \\
$27 \mathrm{~b}$ & 1.5 & 391.79 & 123.59 & 1.88 & 11.9 & 2.47 \\
$28 \mathrm{a}$ & 2.0 & 390.25 & 121.24 & 4.19 & 11.3 & 1.82 \\
$28 \mathrm{~b}$ & 2.0 & 393.88 & 122.90 & 2.35 & 12.7 & 6.45 \\
\hline
\end{tabular}

(1) Diameter of Stainless Steel Beaker $13.1 \mathrm{~cm}$ Height of Stainless Steel Beaker $10.4 \mathrm{~cm}$ 
Table B.12 Recoverability Test Results

\begin{tabular}{|c|c|c|c|c|}
\hline $\begin{array}{c}\text { Run } \\
\text { Number }\end{array}$ & $\begin{array}{c}\text { Sample } \\
\text { Mass } \\
\text { (g) }\end{array}$ & $\begin{array}{c}\text { Dissolution } \\
\text { Time } \\
\text { (min) }\end{array}$ & $\begin{array}{c}\text { Volume of } \\
\text { Filtrate } \\
(\mathrm{ml})\end{array}$ & $\begin{array}{c}\text { Cerium } \\
\text { Concentration } \\
(\mathrm{mg} / l) \\
\end{array}$ \\
\hline $1 a^{(1)}$ & N/A & N/A & N/A & N/A \\
\hline $1 b^{(1)}$ & N/A & N/A & N/A & $\mathrm{N} / \mathrm{A}$ \\
\hline $2 \mathrm{a}$ & 20.31 & 20 & 90 & 1654 \\
\hline $2 b$ & 20.03 & 20 & 99 & 338.3 \\
\hline $3 a$ & 20.38 & 20 & 92 & 976.0 \\
\hline $3 b$ & 20.20 & 20 & 96 & 467.3 \\
\hline $4 a$ & 20.11 & 20 & 90 & 274.1 \\
\hline $4 b$ & 20.09 & 20 & 98 & 747.3 \\
\hline $5 a$ & 20.08 & 20 & 91 & 1470 \\
\hline $5 b$ & 20.17 & 20 & 97 & 278.6 \\
\hline $6 a$ & 20.17 & 20 & 96 & 1353 \\
\hline $6 b$ & 20.06 & 20 & 96 & 317.8 \\
\hline $7 \mathrm{a}$ & 20.21 & 20 & 89 & 667.9 \\
\hline $7 b$ & 20.03 & 20 & 97 & 361.9 \\
\hline $8 a$ & 20.11 & 20 & 93 & 700.2 \\
\hline $8 b$ & 20.06 & 20 & 95 & 346.5 \\
\hline $9 \mathrm{a}$ & 20.04 & 20 & 88 & 1935 \\
\hline $9 b$ & 20.16 & 20 & 98 & 429.8 \\
\hline $10 \mathrm{a}$ & 20.06 & 20 & 95 & 1143 \\
\hline $10 \mathrm{~b}$ & 20.03 & 20 & 97 & 246.3 \\
\hline $11 \mathrm{a}$ & 20.36 & 20 & 91 & 1837 \\
\hline $11 \mathrm{~b}$ & 20.10 & 20 & 96 & 399.8 \\
\hline $12 \mathrm{a}$ & 20.05 & 20 & 93 & 2569 \\
\hline $12 b$ & 20.13 & 20 & 96 & 300.9 \\
\hline $13 a-1$ & 20.05 & 20 & 87 & 363.9 \\
\hline (2) & - & - & - & 400.1 \\
\hline (3) & - & - & - & 400 \\
\hline $13 a-2$ & 20.15 & 20 & 84 & 429.4 \\
\hline $13 b-1$ & 20.18 & 20 & 98 & 994.3 \\
\hline (2) & - & - & - & 987.3 \\
\hline (3) & - & - & - & 987 \\
\hline $13 b-2$ & 2019 & 20 & 99 & 895.7 \\
\hline
\end{tabular}

(1) Recoverability Test was not performed

(2) Analysis performed by ICP-MS using same sample as first analysis

(3) Analysis performed by ICP-MS using a second sample 
WSRC-TR-98-00380

Revision 0

Table B.12 Continued

\begin{tabular}{|c|c|c|c|c|}
\hline $\begin{array}{c}\text { Run } \\
\text { Number }\end{array}$ & $\begin{array}{c}\text { Sample } \\
\text { Mass } \\
(\mathrm{g})\end{array}$ & $\begin{array}{l}\text { Dissolution } \\
\text { Time } \\
\text { (min) }\end{array}$ & $\begin{array}{l}\text { Volume of } \\
\text { Filtrate } \\
(\mathrm{ml})\end{array}$ & $\begin{array}{c}\text { Cerium } \\
\text { Concentration } \\
(\mathrm{mg} / l)\end{array}$ \\
\hline $14 a-1$ & 20.16 & 20 & 92 & 256.4 \\
\hline$(2)$ & - & - & - & 315.3 \\
\hline (3) & - & - & - & 315 \\
\hline $14 a-2$ & 20.01 & 20 & 96 & 312.4 \\
\hline $14 b-1$ & 20.15 & 20 & 97 & 912.0 \\
\hline (2) & - & - & - & 649.2 \\
\hline (3) & - & - & - & 649 \\
\hline $14 b-2$ & 20.15 & 20 & 100 & 804.5 \\
\hline $15 \mathrm{a}$ & 20.08 & 20 & 89 & 1143 \\
\hline (2) & - & - & - & 1251 \\
\hline (3) & - & - & - & 1159 \\
\hline $15 b$ & 20.15 & 20 & 97 & 255.8 \\
\hline (2) & - & - & - & 285.6 \\
\hline (3) & - & - & - & 357 \\
\hline $16 a$ & 20.03 & 20 & 91 & 1289 \\
\hline (2) & - & - & - & 1261 \\
\hline (3) & - & - & - & 1245 \\
\hline $16 \mathrm{~b}$ & 20.08 & 20 & 95 & 302.9 \\
\hline (2) & - & - & - & 332.9 \\
\hline (3) & - & - & - & 305 \\
\hline $17 a$ & 20.03 & 20 & 89 & 945.3 \\
\hline (2) & - & - & - & 1041 \\
\hline (3) & - & - & - & 1214 \\
\hline $17 \mathrm{~b}$ & 20.18 & 20 & 88 & 303.8 \\
\hline (2) & - & - & - & 311.9 \\
\hline (3) & - & - & - & 383 \\
\hline $18 \mathrm{a}$ & 20.07 & 20 & 92 & 1026 \\
\hline (2) & - & - & - & 1075 \\
\hline (3) & - & - & - & 1146 \\
\hline $18 \mathrm{~b}$ & 20.05 & 20 & 93 & 408.9 \\
\hline (2) & - & - & - & 430.9 \\
\hline (3) & - & - & - & 237 \\
\hline
\end{tabular}

(1) Recoverability Test was not performed

(2) Analysis performed by ICP-MS using same sample as first analysis

(3) Analysis performed by ICP-MS using a second sample 
Table B.12 Continued

\begin{tabular}{ccccc}
\hline \hline $\begin{array}{c}\text { Run } \\
\text { Number }\end{array}$ & $\begin{array}{c}\text { Sample } \\
\text { Mass } \\
(\mathrm{g})\end{array}$ & $\begin{array}{c}\text { Dissolution } \\
\text { Time } \\
(\mathrm{min})\end{array}$ & $\begin{array}{c}\text { Volume of } \\
\text { Filtrate } \\
(\mathrm{ml})\end{array}$ & $\begin{array}{c}\text { Cerium } \\
\text { Concentration } \\
(\mathrm{mg} / \mathrm{l})\end{array}$ \\
\hline $19 \mathrm{a}$ & 20.04 & 20 & 90 & 465.4 \\
$19 \mathrm{~b}$ & 20.00 & 20 & 99 & 956.6 \\
$20 \mathrm{a}$ & 20.23 & 20 & 96 & 359.1 \\
$20 \mathrm{~b}$ & 20.14 & 20 & 96 & 823.8 \\
$21 \mathrm{a}$ & 20.17 & 20 & 90 & 631.5 \\
$21 \mathrm{~b}$ & 20.06 & 20 & 97 & 687.6 \\
$22 \mathrm{a}$ & 20.01 & 20 & 94 & 596.7 \\
$22 \mathrm{~b}$ & 20.24 & 20 & 97 & 850.8 \\
$23 \mathrm{a}$ & 20.01 & 20 & 88 & 801.8 \\
$23 \mathrm{~b}$ & 20.26 & 20 & 97 & 813.7 \\
$24 \mathrm{a}$ & 20.16 & 20 & 90 & 703.2 \\
$24 \mathrm{~b}$ & 20.19 & 20 & 98 & 897.1 \\
$25 \mathrm{a}$ & 20.00 & 20 & 89 & 880.1 \\
$25 \mathrm{~b}$ & 20.12 & 20 & 98 & 579.4 \\
$26 \mathrm{a}$ & 20.21 & 20 & 90 & 626.3 \\
$26 \mathrm{~b}$ & 20.18 & 20 & 92 & 765.6 \\
$27 \mathrm{a}$ & 20.11 & 20 & 94 & 740.1 \\
$27 \mathrm{~b}$ & 20.13 & 20 & 94 & 1334 \\
$28 \mathrm{a}$ & 20.14 & 20 & 79 & 659.1 \\
$28 \mathrm{~b}$ & 20.03 & 20 & 95 & 684.5 \\
\hline Re & 20 & & \\
\hline
\end{tabular}

(1) Recoverability Test was not performed

(2) Analysis performed by ICP-MS using same sample as first analysis

(3) Analysis performed by ICP-MS using a second sample 
Full-scale Immobilization Experiments

Table B.13 Waste Form Formulation Data

\begin{tabular}{ccccccc}
\hline $\begin{array}{c}\text { Run } \\
\text { Number }\end{array}$ & $\begin{array}{c}\text { Frit } \\
\text { Particle } \\
\text { Size } \\
(\mu \mathrm{m})\end{array}$ & $\begin{array}{c}\text { Frit to } \\
\text { Residue } \\
\text { Ratio }\end{array}$ & $\begin{array}{c}\text { Mass of } \\
\text { Graphite }\end{array}$ & $\begin{array}{c}\text { Mass of } \\
\mathrm{CaF}_{2}\end{array}$ & $\begin{array}{c}\text { Mass of } \\
\mathrm{CeO}_{2}\end{array}$ & $\begin{array}{c}\text { Mass of } \\
\text { Frit }\end{array}$ \\
\hline FS-1 & 10 & 4 & 508.0 & $(\mathrm{~g})$ & $(\mathrm{g})$ & $(\mathrm{g})$ \\
FS-2 & 10 & 4 & 581.5 & 0.0 & 70.3 & 2310.3 \\
FS-3 & 10 & 4 & 519.0 & 107.1 & 84.4 & 2640.0 \\
FS-4 & 10 & 4 & 519.1 & 107.0 & 85.0 & 2843.4 \\
FS-5 & 10 & 4 & 518.9 & 107.6 & 85.1 & 2848.1 \\
\hline
\end{tabular}

Table B.14 Waste Form Fabrication Data Prior to Heating

\begin{tabular}{ccccccc}
\hline \hline $\begin{array}{c}\text { Run } \\
\text { Number }\end{array}$ & $\begin{array}{c}\text { Fabrication } \\
\text { Temp }{ }^{(1)}\end{array}$ & $\begin{array}{c}\text { Empty } \\
\text { Beaker } \\
\text { Mass } \\
(\mathrm{g})\end{array}$ & $\begin{array}{c}\text { Full } \\
\text { Beaker } \\
\text { Mass } \\
(\mathrm{g})\end{array}$ & $\begin{array}{c}\text { Mass of } \\
\text { Starting } \\
\text { Materials } \\
(\mathrm{g})\end{array}$ & $\begin{array}{c}\text { Depth to } \\
\text { Material } \\
\text { Surface } \\
(\mathrm{cm})\end{array}$ & $\begin{array}{c}\text { Density of } \\
\text { Starting } \\
\text { Materials } \\
\left(\mathrm{g} / \mathrm{cm}^{3}\right)\end{array}$ \\
\hline FS-1 & 700 & 759.5 & 3681.8 & 2911.8 & 6.9 & 0.81 \\
FS-2 & 700 & 760.4 & 4069.6 & 3298.8 & 4.0 & 0.76 \\
FS-3 & 700 & 760.7 & 4325.3 & 3554.2 & 3.0 & 0.78 \\
FS-4 & 700 & 759.5 & 4325.5 & 3555.6 & 3.0 & 0.78 \\
FS-5 & 700 & 767.1 & 4335.3 & 3557.6 & 4.0 & 0.82 \\
\hline
\end{tabular}

(1) Waste Form Centerline Temperature

(2) Diameter of Stainless Steel Beaker $18.0 \mathrm{~cm}$

Height of Stainless Steel Beaker $22.6 \mathrm{~cm}$

Table B.15 Waste Form Fabrication Data After Heating

\begin{tabular}{ccccccc}
\hline \hline $\begin{array}{c}\text { Run } \\
\text { Number }\end{array}$ & $\begin{array}{c}\text { Heating } \\
\text { Time }\end{array}$ & $\begin{array}{c}\text { Beaker } \\
\text { Mass }\end{array}$ & $\begin{array}{c}\text { Waste } \\
\text { Form } \\
\text { Mass } \\
(\mathrm{g})\end{array}$ & $\begin{array}{c}\text { Mass Loss } \\
\text { Upon } \\
\text { Heating } \\
(\mathrm{g})\end{array}$ & $\begin{array}{c}\text { Depth to } \\
\text { Material } \\
\text { Surface } \\
(\mathrm{cm})\end{array}$ & $\begin{array}{c}\text { Density of } \\
\text { Waste } \\
\text { Form }^{(1)}\end{array}$ \\
\hline FS-1 & 0.5 & 3639.0 & 2869.0 & 42.8 & 12.5 & 1.33 \\
FS-2 & 0.5 & 4023.7 & 3252.9 & 45.9 & 11.3 & 1.32 \\
FS-3 & 0.5 & 4280.1 & 3509.0 & 45.2 & 11.6 & 1.47 \\
FS-4 & 0.5 & 4280.0 & 3509.2 & 45.5 & 11.2 & 1.41 \\
FS-5 & 2.0 & 4287.1 & 3509.4 & 48.2 & 10.6 & 1.33 \\
\hline
\end{tabular}

(1) Diameter of Stainless Steel Beaker $18.0 \mathrm{~cm}$

Height of Stainless Steel Beaker $22.6 \mathrm{~cm}$

(2) Centerline Temperature was Maintained at $700^{\circ} \mathrm{C}$ for Designated Time 
WSRC-TR-98-00380

Revision 0

Table B.16 Recoverability Test Results

\begin{tabular}{|c|c|c|c|c|}
\hline $\begin{array}{c}\text { Run } \\
\text { Number }\end{array}$ & $\begin{array}{l}\text { Sample } \\
\text { Mass } \\
(\mathrm{g})\end{array}$ & $\begin{array}{c}\text { Dissolution } \\
\text { Time } \\
\text { (min) }\end{array}$ & $\begin{array}{c}\text { Volume of } \\
\text { Filtrate } \\
(\mathrm{ml})\end{array}$ & $\begin{array}{c}\text { Cerium } \\
\begin{array}{c}\text { Concentration } \\
(\mathrm{mg} / l)\end{array} \\
\end{array}$ \\
\hline$\overline{F S-1 / 1^{(1)}}$ & 20.14 & 20 & 92 & 921.3 \\
\hline FS- $1 / 2^{(2)}$ & 20.04 & 20 & 93 & 1044 \\
\hline FS- $1 / 3^{(3)}$ & 20.00 & 20 & 92 & 1083 \\
\hline FS- $1 / 4^{(4)}$ & 20.01 & 20 & 92 & 843.8 \\
\hline FS-2/1 & 20.07 & 20 & 92 & 843.4 \\
\hline $\mathrm{FS}-2 / 2$ & 20.04 & 20 & 92 & 795.2 \\
\hline $\mathrm{FS}-2 / 3$ & 20.03 & 15 & 92 & 771.5 \\
\hline FS-2/4 & 20.03 & 15 & 92 & 730.7 \\
\hline FS-3/1 & 20.04 & 20 & 91 & 1653 \\
\hline FS-3/2 & 20.07 & 20 & 94 & 2046 \\
\hline FS-3/3 & 20.04 & 15 & 92 & 2038 \\
\hline FS-3/4 & 20.01 & 20 & 91 & 1943 \\
\hline FS-4/1 & 20.03 & 20 & 90 & 998.9 \\
\hline $\mathrm{FS}-4 / 2$ & 20.04 & 20 & 90 & 1037 \\
\hline FS-4/3 & 20.26 & 20 & 94 & 1125 \\
\hline FS-4/4 & 20.27 & 20 & 90 & 1289 \\
\hline FS-5/1 & 20.01 & 20 & 92 & 1723 \\
\hline FS-5/2 & 20.10 & 20 & 95 & 2113 \\
\hline FS-5/3 & 20.06 & 20 & 91 & 2546 \\
\hline FS-5/4 & 20.07 & 20 & 94 & 2333 \\
\hline
\end{tabular}

(1) Sample Removed from Top of Waste Form

(2) Sample Removed from Middle of Waste Form

(3) Sample Removed from Bottom of Waste Form

(4) Composite Sample of Waste Form 
Immobilization of Actual Graphite Fines

Table B.17 Waste Form Formulation Data

\begin{tabular}{ccccccc}
\hline \hline $\begin{array}{c}\text { Run } \\
\text { Number }\end{array}$ & $\begin{array}{c}\text { Frit } \\
\text { Particle } \\
\text { Size } \\
(\mu \mathrm{m})\end{array}$ & $\begin{array}{c}\text { Frit to } \\
\text { Residue } \\
\text { Ratio }\end{array}$ & $\begin{array}{c}\text { Mass of } \\
\text { Graphite } \\
\text { Fines } \\
(\mathrm{g})\end{array}$ & $\begin{array}{c}\text { Mass of } \\
\mathrm{CaF}_{2}\end{array}$ & $\begin{array}{c}\text { Mass of } \\
\mathrm{CeO}_{2}\end{array}$ & $\begin{array}{c}\text { Mass of } \\
\text { Frit }\end{array}$ \\
\hline RM-1 & 10 & 4 & 92.68 & 0.00 & 0.00 & 370.98 \\
RM-2 & 10 & 4 & 95.35 & 0.00 & 0.00 & 381.50 \\
RM-3 & 10 & 4 & 100.94 & 0.00 & 5.10 & 400.00 \\
RM-4 & 10 & 4 & 96.70 & 15.00 & 0.00 & 460.80 \\
\hline
\end{tabular}

Table B.18 Waste Form Fabrication Data Prior to Heating

\begin{tabular}{ccccccc}
\hline \hline $\begin{array}{c}\text { Run } \\
\text { Number }\end{array}$ & $\begin{array}{c}\text { Fabrication } \\
\text { Temp }\end{array}$ & $\begin{array}{c}\text { Empty } \\
\text { Beaker } \\
\text { Mass }\end{array}$ & $\begin{array}{c}\text { Full } \\
\text { Beaker } \\
\text { Mass }^{(1)} \\
(\mathrm{g})\end{array}$ & $\begin{array}{c}\text { Mass of } \\
\text { Starting } \\
\text { Materials } \\
(\mathrm{g})\end{array}$ & $\begin{array}{c}\text { Depth to } \\
\text { Material } \\
\text { Surface } \\
(\mathrm{cm})\end{array}$ & $\begin{array}{c}\text { Density of } \\
\text { Starting } \\
\text { Materials } \\
\left(\mathrm{g} / \mathrm{cm}^{3}\right)\end{array}$ \\
\hline RM-1 & 700 & 286.72 & 750.38 & 463.66 & 8.9 & 0.88 \\
RM-2 & 700 & 301.75 & 778.60 & 476.85 & 9.5 & 1.01 \\
RM-3 & 700 & 304.14 & 810.18 & 506.04 & 8.3 & 0.87 \\
RM-4 & 700 & 311.04 & 883.54 & 572.50 & 7.0 & 0.84 \\
\hline
\end{tabular}

(1) Mass Before Heating was Calculated from Masses of Beaker and Starting Materials

(2) Mass of Starting Materials

(3) Diameter of Stainless Steel Beaker $15.1 \mathrm{~cm}$

Height of Stainless Steel Beaker $10.4 \mathrm{~cm}$

Table B.19 Waste Form Fabrication Data After Heating

\begin{tabular}{ccccccc}
\hline \hline $\begin{array}{c}\text { Run } \\
\text { Number }\end{array}$ & $\begin{array}{c}\text { Heating } \\
\text { Time }\end{array}$ & $\begin{array}{c}\text { Beaker } \\
\text { Mass }^{(1)}\end{array}$ & $\begin{array}{c}\text { Waste } \\
\text { Form } \\
\text { Mass } \\
(\mathrm{g})\end{array}$ & $\begin{array}{c}\text { Mass Loss } \\
\text { Upon } \\
\text { Heating } \\
(\mathrm{g})\end{array}$ & $\begin{array}{c}\text { Depth to } \\
\text { Material } \\
\text { Surface } \\
(\mathrm{cm})\end{array}$ & $\begin{array}{c}\text { Density of } \\
\text { Waste } \\
\text { Form }^{(2)}\end{array}$ \\
\hline RM-1 & 0.5 & 743.38 & 456.66 & 7.00 & 9.5 & 0.96 \\
RM-2 & 2.0 & 771.60 & 469.85 & 7.00 & 11.4 & 1.51 \\
RM-3 & 2.0 & 803.18 & 499.04 & 7.00 & 11.4 & 1.60 \\
RM-4 & 2.0 & 876.54 & 565.50 & 7.00 & 10.8 & 1.55 \\
\hline
\end{tabular}

(1) A Mass Loss of $7 \mathrm{~g}$ was Assumed Based on Feasibility Experiments and $\mathrm{CaF}_{2}$ Variability Study

(2) Diameter of Stainless Steel Beaker $15.1 \mathrm{~cm}$

Height of Stainless Steel Beaker $10.3 \mathrm{~cm}$ 
WSRC-TR-98-00380

Revision 0

Table B.20 Recoverability Test Results

\begin{tabular}{cccccc}
\hline \hline $\begin{array}{c}\text { Run } \\
\text { Number }\end{array}$ & $\begin{array}{c}\text { Sample } \\
\text { Mass } \\
(\mathrm{g})\end{array}$ & $\begin{array}{c}\text { Dissolution } \\
\text { Time } \\
(\mathrm{min})\end{array}$ & $\begin{array}{c}\text { Volume of } \\
\text { Filtrate } \\
(\mathrm{ml})\end{array}$ & $\begin{array}{c}\text { Plutonium } \\
\text { Concentration } \\
(\mathrm{mg} / \mathrm{l})\end{array}$ & $\begin{array}{c}\text { Cerium } \\
\text { Concentration } \\
(\mathrm{mg} / \mathrm{l})\end{array}$ \\
\hline RM-1 & 20.56 & 20 & 84 & 1873 & N/A \\
RM-2 & 20.07 & 20 & 92 & 988 & N/A \\
RM-3 & 20.01 & 20 & 92 & 856 & 1.80 \\
RM-4 & 20.20 & 20 & 90 & 708 & N/A \\
\hline
\end{tabular}




\section{Appendix C Offgas Analyses for Graphite Fines Immobilization}

Table C.1 Offgas Analyses from Baseline (No. 1) Experiment

\begin{tabular}{ccccc}
\hline \hline Sample ID & $\begin{array}{c}\text { Sample Time } \\
(\mathrm{min})\end{array}$ & $\begin{array}{c}\mathrm{CO} \\
\text { Concentration } \\
(\text { vol\%) }\end{array}$ & $\begin{array}{c}\mathrm{CO}_{2} \\
\text { Concentration } \\
(\text { vol\% })\end{array}$ & $\begin{array}{c}\mathrm{O}_{2} \\
\text { Concentration } \\
(\text { vol\%) }\end{array}$ \\
\hline B1-1 & 0 & $<0.002$ & 0.12 & 19.6 \\
B1-2 & 20 & 0.007 & 0.36 & 20.0 \\
B1-3 & 40 & 0.013 & 0.72 & 19.8 \\
B1-4 & 60 & 0.014 & 0.84 & 19.1 \\
B1-5 & 80 & 0.012 & 0.86 & 19.7 \\
B1-6 & 100 & 0.007 & 0.74 & 19.6 \\
B1-7 & 120 & 0.006 & 0.65 & 19.3 \\
\hline
\end{tabular}

Table C.2 Offgas Analyses from Run Number 1

\begin{tabular}{ccccc}
\hline \hline Sample ID & Sample Time & $\begin{array}{c}\mathrm{CO} \\
\text { Concentration } \\
(\text { vol\%) }\end{array}$ & $\begin{array}{c}\mathrm{CO}_{2} \\
\text { Concentration } \\
(\text { vol\%) }\end{array}$ & $\begin{array}{c}\mathrm{O}_{2} \\
\text { Concentration } \\
\text { (vol\%) }\end{array}$ \\
\hline $1-1$ & 0 & 0.008 & 4.4 & 11.7 \\
$1-2$ & 20 & 0.003 & 6.5 & 7.9 \\
$1-3$ & 40 & 0.010 & 6.3 & 9.8 \\
$1-4$ & 60 & 0.011 & 5.7 & 10.9 \\
$1-5$ & 80 & 0.011 & 5.5 & 11.9 \\
$1-6$ & 100 & 0.012 & 3.9 & 15.7 \\
$1-7$ & 120 & 0.024 & 4.8 & 13.9 \\
\hline
\end{tabular}

Table C.3 Offgas Analyses from Run Number 2

\begin{tabular}{ccccc}
\hline \hline Sample ID & Sample Time & $\begin{array}{c}\mathrm{CO} \\
\text { Concentration } \\
(\mathrm{vol} \%)\end{array}$ & $\begin{array}{c}\mathrm{CO}_{2} \\
\text { Concentration } \\
(\mathrm{vol} \%)\end{array}$ & $\begin{array}{c}\mathrm{O}_{2} \\
\text { Concentration } \\
(\mathrm{vol} \%)\end{array}$ \\
\hline $2-1$ & 0 & 0.009 & 4.4 & 14.0 \\
$2-2$ & 20 & 0.004 & 10.5 & 3.5 \\
$2-3$ & 40 & 0.003 & 11.1 & 1.8 \\
$2-4$ & 60 & 0.004 & 12.0 & 1.5 \\
$2-5$ & 80 & 0.003 & 12.5 & 2.2 \\
$2-6$ & 100 & 0.001 & 12.8 & 1.5 \\
$2-7$ & 120 & 0.004 & 13.0 & 3.8 \\
\hline
\end{tabular}


Table C.4 Offgas Analyses from Run Number 3

\begin{tabular}{ccccc}
\hline \hline Sample ID & Sample Time & $\begin{array}{c}\mathrm{CO} \\
\text { Concentration } \\
(\mathrm{vol} \%)\end{array}$ & $\begin{array}{c}\mathrm{CO}_{2} \\
\mathrm{Concentration} \\
(\mathrm{vol} \%)\end{array}$ & $\begin{array}{c}\mathrm{O}_{2} \\
\begin{array}{c}\text { Concentration } \\
(\text { vol\% })\end{array}\end{array}$ \\
\hline $3-1$ & 0 & 0.009 & 2.7 & 18.0 \\
$3-2$ & 20 & 0.006 & 2.1 & 18.5 \\
$3-3$ & 40 & 0.011 & 2.0 & 19.6 \\
$3-4$ & 60 & 0.012 & 1.8 & 19.4 \\
$3-5$ & 80 & 0.012 & 1.7 & 19.1 \\
$3-6$ & 100 & 0.012 & 1.2 & 20.0 \\
$3-7$ & 120 & 0.012 & 1.3 & 20.4 \\
\hline
\end{tabular}

Table C.5 Offgas Analyses from Run Number 4

\begin{tabular}{ccccc}
\hline \hline Sample ID & Sample Time & $\begin{array}{c}\mathrm{CO} \\
\text { Concentration } \\
\text { (vol\%) }\end{array}$ & $\begin{array}{c}\mathrm{CO}_{2} \\
\text { Concentration } \\
(\text { vol\%) }\end{array}$ & $\begin{array}{c}\mathrm{O}_{2} \\
\text { Concentration } \\
(\text { vol\% })\end{array}$ \\
\hline $4-1$ & 0 & 0.001 & 7.8 & 7.1 \\
$4-2$ & 20 & 0.013 & 8.0 & 6.7 \\
$4-3$ & 40 & 0.026 & 8.7 & 5.9 \\
$4-4$ & 60 & 0.023 & 9.1 & 5.8 \\
$4-5$ & 80 & 0.019 & 8.9 & 6.5 \\
$4-6$ & 100 & 0.014 & 9.0 & 7.2 \\
$4-7$ & 120 & 0.013 & 8.8 & 7.6 \\
\hline
\end{tabular}

Table C.6 Offgas Analyses from Run Number 5/1

\begin{tabular}{ccccc}
\hline \hline Sample ID & $\begin{array}{c}\text { Sample Time } \\
(\mathrm{min})\end{array}$ & $\begin{array}{c}\mathrm{CO} \\
\text { Concentration } \\
\text { (vol\%) }\end{array}$ & $\begin{array}{c}\mathrm{CO}_{2} \\
\text { Concentration } \\
(\mathrm{vol} \%)\end{array}$ & $\begin{array}{c}\mathrm{O}_{2} \\
\text { Concentration } \\
\text { (vol\%) }\end{array}$ \\
\hline $5 / 1-1$ & 0 & 0.003 & 11.5 & 1.5 \\
$5 / 1-2$ & 20 & 0.150 & 8.6 & $1^{(1)}$ \\
$5 / 1-3$ & 40 & 0.250 & 6.8 & $1^{(1)}$ \\
$5 / 1-4$ & 60 & 0.210 & 6.3 & $1^{(1)}$ \\
$5 / 1-5$ & 80 & 0.170 & 5.6 & $1^{(1)}$ \\
$5 / 1-6$ & 100 & 0.120 & 5.1 & $1^{(1)}$ \\
$5 / 1-7$ & 120 & 0.100 & 5.0 & $1^{(1)}$ \\
\hline
\end{tabular}

(1) A negative bias influence was observed consistent with the presence of argon or a compound with argon-similar elution characteristics. 
Table C.7 Offgas Analyses from Baseline (No. 2) Experiment

\begin{tabular}{ccccc}
\hline \hline Sample ID & $\begin{array}{c}\text { Sample Time } \\
(\min )\end{array}$ & $\begin{array}{c}\mathrm{CO} \\
\text { Concentration } \\
(\text { vol\%) }\end{array}$ & $\begin{array}{c}\mathrm{CO}_{2} \\
\text { Concentration } \\
(\text { vol\%) }\end{array}$ & $\begin{array}{c}\mathrm{O}_{2} \\
\text { Concentration } \\
\text { (vol\%) }\end{array}$ \\
\hline B2-1 & 0 & $<0.01$ & 0.47 & 20.0 \\
B2-2 & 20 & $<0.01$ & 0.62 & 20.0 \\
B2-3 & 40 & $<0.01$ & 0.53 & 22.2 \\
B2-4 & 60 & $<0.01$ & 0.41 & 19.5 \\
B2-5 & 80 & $<0.01$ & 0.57 & 19.7 \\
B2-6 & 100 & $<0.01$ & 0.24 & 21.6 \\
B2-7 & 120 & $<0.01$ & 0.28 & 19.7 \\
\hline
\end{tabular}

Table C.8 Offgas Analyses from Run Number 5/2

\begin{tabular}{ccccc}
\hline \hline Sample ID & $\begin{array}{c}\text { Sample Time } \\
(\min )\end{array}$ & $\begin{array}{c}\mathrm{CO} \\
\text { Concentration } \\
(\text { vol\%) }\end{array}$ & $\begin{array}{c}\mathrm{CO}_{2} \\
\text { Concentration } \\
\text { (vol\%) }\end{array}$ & $\begin{array}{c}\mathrm{O}_{2} \\
\text { Concentration } \\
\text { (vol\%) }\end{array}$ \\
\hline $5 / 2-1$ & 0 & $<0.002$ & $9.9 \pm 0.5^{(1)}$ & 1.2 \\
$5 / 2-2$ & 20 & $<0.002$ & 9.6 & 5.0 \\
$5 / 2-3$ & 40 & $<0.002$ & 13.1 & 2.5 \\
$5 / 2-4$ & 60 & $<0.002$ & $13.6 \pm 0.4^{(1)}$ & 1.5 \\
$5 / 2-5$ & 80 & $<0.002$ & 13.9 & 2.7 \\
$5 / 2-6$ & 100 & $<0.002$ & 13.2 & 2.1 \\
$5 / 2-7$ & 120 & $<0.002$ & 14.0 & 1.3 \\
\hline
\end{tabular}

(1) Samples reported with uncertainty values are actual estimated uncertainty from the analysis of replicate samples

Table C.9 Offgas Analyses from Run Number 6

\begin{tabular}{ccccc}
\hline \hline Sample ID & $\begin{array}{c}\text { Sample Time } \\
(\mathrm{min})\end{array}$ & $\begin{array}{c}\mathrm{CO} \\
\text { Concentration } \\
(\text { vol\%) }\end{array}$ & $\begin{array}{c}\mathrm{CO}_{2} \\
\text { Concentration } \\
(\text { vol\%) }\end{array}$ & $\begin{array}{c}\mathrm{O}_{2} \\
\text { Concentration } \\
\text { (vol\%) }\end{array}$ \\
\hline $6-1$ & 0 & $<0.002$ & 3.2 & 16.5 \\
$6-2$ & 20 & $<0.002$ & 2.6 & 17.0 \\
$6-3$ & 40 & $<0.002$ & 2.5 & 17.3 \\
$6-4$ & 60 & $<0.002$ & 2.3 & 17.4 \\
$6-5$ & 80 & $<0.002$ & 2.3 & 17.2 \\
$6-6$ & 100 & $<0.002$ & 2.2 & 18.1 \\
$6-7$ & 120 & $<0.002$ & 1.9 & 17.3 \\
\hline
\end{tabular}


Table C.10 Offgas Analyses from Run Number 7

\begin{tabular}{ccccc}
\hline \hline Sample ID & $\begin{array}{c}\text { Sample Time } \\
(\mathrm{min})\end{array}$ & $\begin{array}{c}\mathrm{CO} \\
\mathrm{Concentration} \\
(\mathrm{vol} \%)\end{array}$ & $\begin{array}{c}\mathrm{CO}_{2} \\
\mathrm{Concentration} \\
(\text { vol\%) }\end{array}$ & $\begin{array}{c}\mathrm{O}_{2} \\
\text { Concentration } \\
(\text { vol\%) }\end{array}$ \\
\hline $7-1$ & 0 & $<0.002$ & 7.0 & 10.2 \\
$7-2$ & 20 & $<0.002$ & 6.7 & 13.0 \\
$7-3$ & 40 & $<0.002$ & 5.8 & 12.0 \\
$7-4$ & 60 & $<0.002$ & 4.9 & 13.8 \\
$7-5$ & 80 & $<0.002$ & 4.1 & 15.0 \\
$7-6$ & 100 & $<0.002$ & 2.8 & 18.1 \\
$7-7$ & 120 & $<0.002$ & 2.3 & 17.3 \\
\hline
\end{tabular}

